\title{
PENGARUH PERENCANAAN KERJA DAN KOMUNIKASI TERHADAP KINERJA KARYAWAN PADA PT TITIPAN MAS AREA V MAKASSAR
}

Tesis

untuk memenuhi sebagian persyaratan mencapai derajat Magister

Program Studi Magister Manajemen

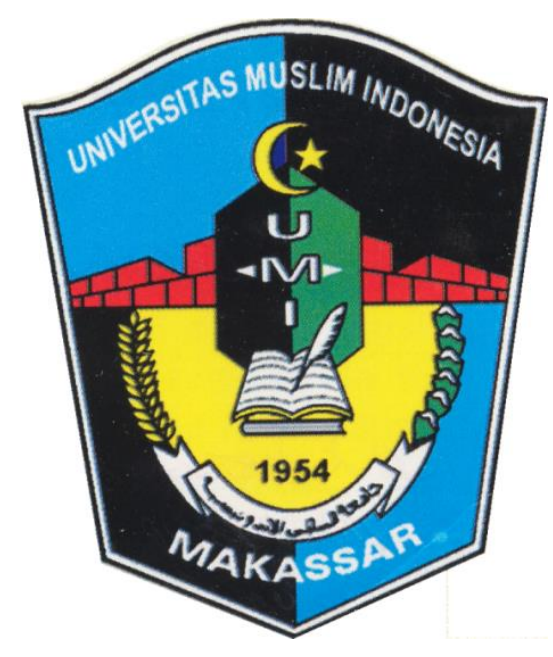


AJMAL AS'AD

0160.01 .37 .2012

\title{
PROGRAM PASCASARJANA \\ UNIVERSITAS MUSLIM INDONESIA
}

MAKASSAR

2015

Tesis

\section{PENGARUH PERENCANAAN KERJA DAN KOMUNIKASI TERHADAP KINERJA KARYAWAN PADA PT TITIPAN MAS AREA V MAKASSAR}

\author{
AJMAL AS'AD \\ 0160.01.37.2012
}

disetujui untuk diujikan 
Ketua,

Prof. Dr. H. Mahfudnurnajamuddin, SE., MM tanggal

Anggota

Dr. Sabri Hasan, SE., MM

tanggal 


\section{ABSTRAK}

AJMAL AS'AD. Pengaruh Perencanaan Kerja dan Komunikasi terhadap Kinerja Karyawan pada PT Titipan Mas Area V Makassar, dengan pembimbing: $\mathbf{H}$.

\section{MAHFUDNURNAJAMUDDIN dan SABRI HASAN.}

Tujuan penelitian ini adalah untuk: 1) Menganalisis pengaruh perencanaan dan komunikasi terhadap kinerja karyawan pada PT Titipan Mas Area $V$ Makassar, dan 2) Mengetahui variabel yang dominan pengaruhnya terhadap kinerja karyawan pada PT Titipan Mas Area V Makassar.

Data yang digunakan adalah data primer dan data sekunder. Populasi dalam penelitian ini adalah jumlah keseluruhan karyawan PT Titipan Mas Area V Makassar, dengan menggunakan persentase kelonggaran (5\%) maka dari populasi sebanyak 200 orang diperoleh ukuran sampel sebesar 113 responden. Pengumpulan data dilakukan melalui kuesioner, dan dokumentasi. Metode analisis data menggunakan analisis statistik deskriptif, dan regresi linier berganda dengan menggunakan Program SPSS versi 22.

Hasil penelitian menunjukkan bahwa baik secara simultan maupun secara parsial variabel perencanaan kerja dan komunikasi berpengaruh signifikan terhadap kinerja karyawan. Dari kedua variabel bebas tersebut yang paling dominan adalah variabel komunikasi.

Kata kunci: Perencanaan kerja, komunikasi, dan kinerja karyawan. 


\begin{abstract}
AJMAL AS'AD. Influence of Work Planning and Communication to Employee Performance in PT Titipan Mas Area V Makassar, the supervisor: $\mathbf{H}$.

MAHFUDNURNAJAMUDDIN and SABRI HASAN.
\end{abstract}

The purpose of this study was to: 1) to analyze the influence of planning and communication to employees performance at PT Courier Mas Area V Makassar, and 2) Knowing the dominant variable influence on the performance of employees at PT Courier Mas Area V Makassar.

The data used are primary data and secondary data. The population in this study is the total number of employees of PT Courier Mas Area V Makassar, using slack percentage $(5 \%)$ then from a population of 200 people obtained a sample size of 113 respondents. Data collected through questionnaires, and documentation. Methods of data analysis using descriptive statistical analysis, and multiple linear regression using SPSS version 22.

The results showed that either simultaneously or in partial, work planning and communication have a significant effect on the performance of employees. Of the two independent variables is the most dominant communication variables.

Keywords: work planning, communication, and employee performance. 


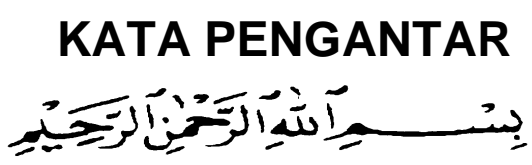

Puji syukur alhamdulillah senantiasa penulis panjatkan ke hadirat Allah SWT atas limpahan karunia-Nya yang telah memberi kesehatan jasmani dan rokhani kepada penulis sehingga dapat menyelesaikan tesis ini guna memenuhi sebagian persyaratan mendapatkan gelar Magister Manajemen Program Pascasarjana Universitas Muslim Indonesia.

Banyak kendala yang dihadapi oleh penulis dalam rangka penyusunan tesis ini, namun berkat bantuan berbagai pihak, akhirnya tesis ini dapat diselesaikan sebagaimana adanya. Untuk itu, dengan ketulusan hati yang dalam, penulis menyampaikan ucapan terima kasih dan penghargaan kepada:

1. Terkhusus kepada Ayahanda dan Ibunda atas doa tulusnya sehingga penulis dapat merampungkan tesis ini tepat pada waktunya.

2. Prof. Dr. Hj. Masrurah Mokhtar, MA, selaku Rektor Universitas Muslim Indonesia.

3. Prof. Dr. H. Basri Modding, SE., M.Si, selaku Direktur Program Pascasarjana Universitas Muslim Indonesia.

4. Prof. Dr. H. Abdul Rahman Mus, SE., M.Si, sebagai Ketua Program Studi Magister Manajemen Universitas Muslim Indonesia.

5. Prof. Dr. H. Mahfudnurnajamuddin, SE., MM. selaku Ketua Komisi Pembimbing dan Dr. Sabri Hasan, SE., MM, selaku anggota Komisi Pembimbing.

6. Prof. Dr. H. Basri Modding, SE.,M.Si, Prof. Dr. H. Baharuddin Semmaila, SE.,M.Si, dan Prof. Dr. H. Syahnur Said, SE.,M.Si, masing-masing selaku Tim Penilai yang telah banyak memberi kritik dan saran kepada penulis demi kesempurnaan tesis ini. 
7. Bapak/lbu dosen pada Program Studi Magister Manajemen Pasca Sarjana Universitas Muslim Indonesia.

8. Pimpinan PT Titipan Mas Area V Makassar beserta karyawan yang telah memberikan data-data dan informasi yang diperlukan dalam penelitian ini.

9. Isteri tercinta Erna Srianty Mustamin, SE yang senantiasa mendoakan dan mendampingi penulis dalam suka dan cita dan anakku tersayang putriku Zhafira Alfatihatha Ajmal dan Zalfa Naqiyya Ajmal yang selalu memberikan kebahagiaan sehingga penulis termotivasi dalam menyelesaikan Pendidikan Magister Manajemen (S2).

10. Kakak kandung penulis Suryani As'ad, Mujahidah As'ad, Sitti Makramah As'ad, Muhammad Rafi As'ad dan Abdul Rasyid As'ad yang tak henti hentinya memberikan dukungan, semangat dan doa yang sangat membantu kelancaran pendidikan ini

11. Teman-teman kelas Manajemen MM-4 seperjuangan angkatan XXXVII yang telah memberikan semangat dan dukungan.

Harapan penulis, semoga segala bantuan baik moril maupun materil dalam berbagai aspeknya senantiasa mendapat imbalan berupa limpahan rahmat dari Allah SWT. Amin Ya Rabbal Alamin.

Makassar, Maret 2015

Penulis,

\section{AJMAL AS'AD}


DAFTAR ISI

Halaman

HALAMAN JUDUL …................................................................

HALAMAN PENGESAHAN ...................................................... ii

KATA PENGANTAR …................................................................ iii

ABSTRAK ………......................................................

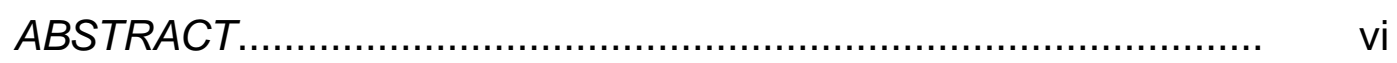

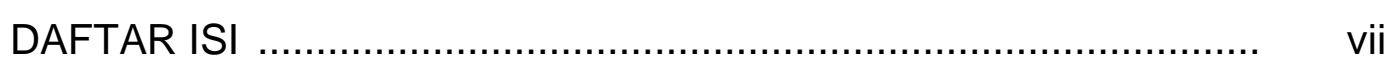

DAFTAR TABEL ...................................................................... ix

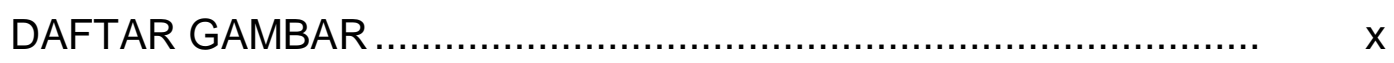

DAFTAR LAMPIRAN ...............................................................

BAB I. PENDAHULUAN ………………….......................... 1

A. Latar Belakang ........................................................ 1

B. Rumusan Masalah .................................................. 7

C. Tujuan Penelitian …………………………........ 8

D. Manfaat Penelitian ...................................................... 8

BAB II. TINJAUAN PUSTAKA ……..................................... 10

A. Manajemen Sumber Daya Manusia …...................... 10

B. Kinerja Karyawan ..................................................... 18

C. Perencanaan ........................................................... 29

D. Komunikasi ....................................................... 41

E. Penelitian Terdahulu .............................................. 50

BAB III. KERANGKA KONSEPTUAL DAN HIPOTESIS ........... 53

A. Kerangka Konseptual............................................. 53

B. Hipotesis ............................................................ 56 
Halaman

BAB IV. METODE PENELITIAN ……................................... 57

A. Pendekatan Penelitian ......................................... 57

B. Lokasi dan Waktu Penelitian................................... 57

C. Jenis dan Sumber Data ..................................... 58

D. Teknik Pengumpulan Data .................................... 58

E. Populasi dan Sampel ......................................... 59

F. Metode Analisis Data ......................................... 61

G. Definisi Operasional dan Pengukurannya ................ 65

BAB V. HASIL PENELITIAN DAN PEMBAHASAN ................. 68

A. Karakteristik Responden ........................................... 68

B. Analisis Deskriptif Variabel Penelitian ...................... $\quad 72$

C. Pengujian Instrumen Penelitian ............................... $\quad 78$

D. Pengujian Asumsi Klasik ........................................ 84

E. Pengujian Hipotesis Penelitian .............................. 88

F. Pembahasan ....................................................... 92

BAB VI SIMPULAN DAN SARAN ........................................... 99

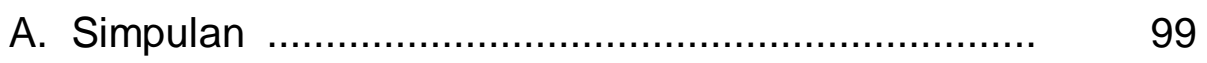

B. Saran ................................................................. 99

DAFTAR PUSTAKA ................................................................ 101

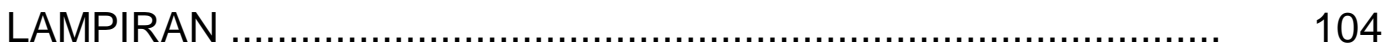




\section{DAFTAR TABEL}

No.

Teks

Halaman

1. Proporsi Sampel Penelitian

60

2. Karakteristik Responden menurut Jenis Kelamin

3. Karakteristik Responden Menurut Tingkat Umur

4. Karakteristik Responden Menurut Tingkat Pendidikan

5. Distribusi Tanggapan Responden terhadap Variabel Kinerja Karyawan

6. Distribusi Tanggapan Responden terhadap Variabel Perencanaan Kerja

7. Distribusi Tanggapan Responden terhadap Variabel Komunikasi

8. Hasil Uji Validitas Instrumen Penelitian

9. Hasil Uji Reliabilitas Instrumen Penelitian

10. Hasil Uji Multikolinearitas

11. Pengujian Secara Simultan (Uji F) 
12. Pengujian Secara Parsial (Uji-t)

13. Hasil Pengujian Koefisien Determinasi $\left(\mathrm{R}^{2}\right)$ 


\section{DAFTAR GAMBAR}

\section{NomorTeks}

Halaman

1. Proses Manajemen Sumber Daya Manusia menurut Cushway

2. Kerangka Konseptual Penelitian.

3. Hasil Uji Normalitas (Lampiran 6)

84

4. Hasil Uji Heterokedastisitas (Lampiran 6)

87 


\section{DAFTAR LAMPIRAN}

\section{NomorTeks}

Halaman

1. Angket Penelitian ....................................... 104

2. Tabulasi Data Hasil Kuesioner Penelitian.................. 107

3. Distribusi Frekuensi Karakteristik Responden............. 111

4. Analisis Distribusi Frekuensi Variabel Penelitian............ 113

5. Hasil Analisis Uji Validitas dan Reliabilitas ................ 117

6. Hasil Analisis Regresi Linier Berganda ................... 119 


\section{BAB I \\ PENDAHULUAN}

\section{A. Latar Belakang}

Manajemen sumber daya manusia pada dasarnya adalah langkahlangkah perencanaan, penarikan, seleksi, pengembangan, pemeliharaan, dan penggunaan sumber daya manusia untuk mencapai tujuan individu maupun organisasi (Handoko, 2001). Oleh karena itu, keberhasilan pengelolaan organisasi sangat ditentukan oleh kegiatan pendayagunaan sumber daya manusia. Sumber daya manusia sangat penting artinya dalam menentukan kelangsungan hidup suatu organisasi.

Organisasi yang baik, tumbuh dan berkembang akan menitikberatkan pada sumber daya manusia (human resources) guna menjalankan fungsinya dengan optimal, khususnya menghadapi dinamika perubahan lingkungan yang terjadi. Dengan demikian kemampuan teknis, teoritis, konseptual, moral dari para pelaku organisasi/perusahaan di semua tingkat (level) pekerjaan sangat dibutuhkan. Selain itu pula kedudukan sumber daya manusia pada posisi yang paling tinggi berguna untuk mendorong perusahaan menampilkan norma perilaku, nilai dan keyakinan sebagai sarana penting dalam peningkatan kinerjanya.

Karyawan merupakan asset yang sangat vital bagi perusahaan. Karena kinerja yang mereka lakukan sangat mempengaruhi efektivitas kinerja perusahaan. Oleh karena itu peningkatan kinerja karyawan menjadi fokus utama unit manajemen sumber daya manusia. Mereka 
berusaha mengembangkan potensi-potensi yang dimiliki oleh individu agar mereka termotivasi untuk memberikan kontribusi terbaik demi pencapaian tujuan-tujuan perusahaan, kinerja karyawan merupakan hasil dari suatu proses atau aktivitas pada fungsi tertentu yang dilaksanakan oleh seseorang baik sebagai individu maupun sebagai anggota dari suatu kelompok atau organisasi pada periode tertentu berdasarkan standar yang telah ditetapkan, dan hasilnya dapat dinikmati sendiri maupun oleh kelompok dalam perusahaan (Arfah dan Anshory,2005).

Kinerja seorang karyawan bersifat individual, karena setiap karyawan mempunyai tingkat kemampuan yang berbeda - beda dalam mengerjakan tugasnya. Pihak manajemen dapat mengukur karyawan atas unjuk kerjanya berdasarkan kinerja dari masing-masing karyawan. Kinerja merupakan suatu hasil yang dicapai oleh pekerja dalam pekerjaannya menurut kriteria tertentu yang berlaku untuk suatu pekerjaan (Robbins, 2002). Pengertian lain, menyatakan kinerja sebagai catatan terhadap hasil produksi dari sebuah pekerjaaan tertentu atau aktivitas tertentu dalam periode tertentu. Selain itu kinerja juga dapat diartikan sebagai suatu hasil dan usaha seseorang yang dicapai dengan adanya kemampuan dan perbuatan dalam situasi tertentu.

Pada umumnya sebagian besar organisasi yang ada percaya bahwa untuk mencapai sebuah keberhasilan, harus mengupayakan kinerja individu semaksimal mungkin, karena pada dasarnya kinerja individu akan sangat berpengaruh terhadap kinerja baik kinerja tim ataupun kelompok yang akhirnya berpengaruh juga terhadap kinerja 
sebuah organisasi. Namun pada kenyataannya untuk memaksimalkan kinerja individu tidaklah semudah itu. Kinerja diasumsikan sebagai prestasi yang diperoleh seseorang dalam melakukan tugas. Keberhasilan organisasi tergantung pada kinerja para pelaku organisasi bersangkutan. Oleh karena itu, setiap unit kerja dalam suatu organisasi harus dinilai kinerjanya, agar kinerja sumber daya manusia yang terdapat dalam unit-unit dalam suatu organisasi tersebut dapat dinilai secara objektif (Anwar, 2000).

Setiap perusahaan ingin karyawannya memiliki kinerja yang tinggi dalam bekerja. Banyak upaya yang dilakukan oleh perusahaan untuk meningkatkan kinerja pegawainya, baik melalui perencanaan, pelatihan, pemberian insentif, jenjang karier, komunikasi dan lain sebagainya. Dengan kinerja pegawai yang tinggi, diharapkan tujuan perusahaan akan dapat tercapai sebagaimana telah direncanakan.

Menurut Miner (1990) dalam Gunawan (2006) kinerja adalah bagaimana seseorang diharapkan dapat berfungsi dan berperilaku sesuai dengan tugas yang telah dibebankan kepadanya. Setiap harapan mengenai bagaimana seseorang harus berperilaku dalam melaksanakan tugas, berarti menunjukkan suatu peran dalam organisasi. Menurut Prawirosentono (2000), suatu organisasi baik organisasi pemerintahan maupun organisasi privat dalam mencapai tujuan yang ditetapkan harus melalui sarana dalam bentuk organisasi yang digerakkan oleh sekelompok orang yang berperan aktif sebagai pelaku (actors) dalam upaya mencapai tujuan lembaga atau organisasi bersangkutan. 
Menurut Miner (1990) dalam Partanto (2007), ada beberapa aspek yang mempengaruhi kinerja. Pertama adalah kualitas yang dihasilkan, menerangkan tentang jumlah kesalahan, waktu, dan ketepatan dalam melakukan tugas. Kedua, kuantitas yang dihasilkan yang berkenaan dengan berapa jumlah produk atau jasa yang dapat dihasilkan. Ketiga, waktu kerja yang menerangkan mengenai berapa jumlah absen, keterlambatan serta masa kerja yang telah dijalani individu pegawai tersebut. Dan yang terakhir adalah kerja sama, yang menjelaskan bagaimana individu membantu atau menghambat usaha dari teman sekerjanya.

Sehubungan dengan kinerja karyawan pada PT Titipan Mas Area V Makassar masih tergolong rendah, hal ini disebabkan karena kurang efektifnya komunikasi antara atasan dan bawahan terkait dengan pelaksanaan tugas pegawai sehingga hasil kerja pegawai kurang maksimal. Begitu pula kemauan pegawai untuk berusaha demi organisasi masih kurang dimana masih ada pegawai yang menggunakan sebagian waktunya melakukan pekerjaan di luar tugas yang menjadi tanggungjawabnya. Selain itu pula, insentif yang diberikan kepada masih kurang mampu memotivasi pegawai karena pegawai masih mencari penghasilan tambahan diselah-selah jam kerja di kantor sehingga pelaksanaan tugas tidak maksimal. Oleh karena itu, ketiga fenomena tersebut yakni komunikasi, komitmen organisasi, dan insentif perlu dikaji karena diyakini mempengaruhi kinerja karyawan pada PT Titipan Mas Area V Makassar. 
Perusahaan akan berusaha untuk selalu meningkatkan kinerja karyawannya demi tercapainya tujuan yang telah ditetapkan perusahaan. Untuk mencapai tujuan kinerja memerlukan karyawan yang mempunyai kinerja kerja yang baik. Berbagai cara bisa ditempuh perusahaan dalam meningkatkan kinerja karyawannya diantaranya sistem perencanaan kerja dan komunikasi efektif antar semua lini dan departemen dalam suatu perusahaan. Kedua variabel ini sangat berperan dalam meningkatkan efektivitas dan efesiensi dari organisasi di dalam menjalankan kegiatan dan pekerjaan yang telah direncanakan dan diprogramkan.

Perencanaan kerja adalah suatu proses mempersiapkan usaha atau kegiatan yang akan dilakukan secara sistematis dan logis untuk mencapai suatu tujuan yang telah ditetapkan sebelumnya secara efektif dan efisien. Sistematis dalam arti teratur dan logis dalam arti masuk akal sehingga bisa dipertanggung jawabkan. Tujuan yang dimaksud sudah tentu dalam artian bukan tujuan individual (perorangan) melainkan merupakan tujuan kolektif (bersama) atau tujuan organisasi (kelompok). Perencanaa kerja disusun dengan cara dan usaha yang paling efektif dan efisien (Sritomo, 2006).

Selanjutnya Robbins dan Coulter (2001) menyatakan dengan perencanaan kerja dapat memberikan pengarahan baik untuk level manajerial maupun non manajerial. Dengan rencana kerja yang jelas Karyawan dapat mengetahui apa yang mereka harus capai, dengan siapa mereka harus bekerjasama dan apa yang mereka lakukan untuk mencapai tujuan organisasi. Tanpa rencana kerja yang baik maka 
departemen dan individual akan bekerja sendiri-sendiri secara serampangan sehingga kinerja organisasi tidak efisien dan efektif. Oleh karena itu, perencanaan perlu dikaji agar dapat diketahui pengaruhnya terhadap kinerja karyawan.

Untuk mencapai kinerja pegawai yang maksimal maka dibutuhkan sebuah komunikasi efektif yang terjadi dalam organisasi. Komunikasi memegang peranan penting dalam suatu interaksi sosial dimana komunikasi merupakan aktivitas dasar manusia. Oleh karena itu, komunikasi akan sangat berpengaruh dalam dunia kerja. Semakin efektif komunikasi yang dibina, maka semakin produktif juga karyawan dalam menjalankan tugasnya (Robbins, 2007).

Dalam melaksanakan pekerjaan, karyawan tidak lepas dari komunikasi dengan sesama rekan sekerja, dengan atasan dan dengan bawahan. Komunikasi yang baik dapat menjadi sarana yang tepat dalam meningkatkan kinerja karyawan. Melalui komunikasi, karyawan dapat meminta petunjuk kepada atasan mengenai pelaksanaan kerja. Melalui komunikasi juga karyawan dapat saling bekerja sama satu sama lain. Komunikasi yang diharapkan dalam dunia kerja adalah komunikasi yang efektif.

Komunikasi disebut efektif atau berhasil apabila makna informasi yang disampaikan oleh pengirim pesan kepada penerima pesan dan makna informasi yang diterima oleh penerima adalah sama (Mulyana, 2004). Ketepatan komunikasi menunjuk pada kemampuan seseorang 
untuk mereproduksi atau menciptakan suatu pesan dengan tepat (Nurdin, 2005).

Sehubungan dengan komunikasi pada PT Titipan Mas Area V Makassar masih kurang efektif, dimana pada kenyataannya komunikasi tidak berjalan sesuai harapan, karena pimpinan dalam memberikan petunjuk kerja kepada masih kurang jelas, begitu pula bawahan belum mampu merespon setiap komunikasi dari atasannya sehingga pegawai dalam melaksanakan tugasnya belum mampu menciptakan hasil yang maksimal. Oleh karena itu, komunikasi perlu dikaji agar dapat diketahui pengaruhnya terhadap kinerja karyawan pada PT Titipan Mas Area V Makassar.

Berdasarkan uraian di atas menjadi dasar dalam melakukan pengkajian ilmiah untuk melakukan penelitian yang berjudul: "Pengaruh Perencanaan dan Komunikasi terhadap Kinerja Karyawan pada PT Titipan Mas Area V Makassar.

\section{B. Rumusan Masalah}

Berdasarkan latar belakang tersebut, maka yang menjadi masalah pokok adalah:

1. Apakah perencanaan dan komunikasi berpengaruh terhadap kinerja karyawan pada PT Titipan Mas Area V Makassar ?

2. Variabel manakah yang paling dominan pengaruhnya terhadap kinerja karyawan pada PT Titipan Mas Area V Makassar? 


\section{Tujuan Penelitian}

Berdasarkan rumusan masalah di atas, maka tujuan penelitian adalah untuk:

1. Menganalisis pengaruh perencanaan dan komunikasi terhadap kinerja karyawan pada PT Titipan Mas Area V Makassar.

2. Mengetahui variabel yang dominan pengaruhnya terhadap kinerja karyawan pada PT Titipan Mas Area V Makassar.

\section{Manfaat Penelitian}

\section{Manfaat Akademik:}

a. Sumbangan teoritis terhadap manajemen sumber daya manusia untuk penelitian yang menghubungkan variabel perencanaan dan komunikasi terhadap kinerja pegawai.

b. Sebagai bahan penelitian selanjutnya yang dapat dilanjutkan dan dikembangkan dalam penelitian yang sejenis atau penelitian lainnya yang masih berkaitan.

c. Menyediakan referensi penulisan ilmiah bagi semua pihak yang berminat mengadakan penelitian lebih lanjut khususnya di bidang organisasi.

\section{Manfaat Praktis}

Berdasarkan permasalahan yang dibahas penelitian ini, maka kegunaan penelitian ini adalah : 
1. Kegunaan teoritis, dapat memperkaya studi tentang manajemen sumber daya manusia, khususnya yang terkait dengan pengaruh perencanaan kerja, komunikasi efektif dan kinerja karyawan. Lebih jauh sebagai bahan referensi bagi penelitian yang akan datang.

2. Kegunaan praktis, hasil penelitian ini untuk dapat memberikan masukan yang berarti bagi manajemen pada PT Titipan Mas Area V Makassar mengenai perencanaan kerja, komunikasi, dan kinerja karyawan merupakan hal yang sangat penting untuk mencapai tujuan perusahaan. 


\section{BAB II}

\section{TINJAUAN PUSTAKA}

\section{A. Manajemen Sumber Daya Manusia}

\section{Pengertian Sumber Daya Manusia}

Sumber daya manusia sering disebut sebagai Human Resource, tenaga atau kekuatan manusia (energy atau power). Sumber daya yang juga disebut sumber tenaga, kemampuan, kekuatan, keahlian yang dimiliki oleh manusia (Fathoni, 2006).

Sumber daya manusia merupakan aset yang paling penting yang harus dimiliki oleh organisasi dan sangat diperhatikan oleh pengelola organisasi tersebut. Istilah sumber daya manusia yang merujuk kepada orang-orang yang ada dalam organisasi. Pada saat pengelola terlibat dalam aktivitas-aktivitas sumber daya manusia sebagai bagian dari pekerjaannya, mereka berupaya manfasilitasi kontribusi yang diajukan

oleh orang-orang yang mr;ncapai rencanarencana dan strategi-strategi organisasi. Artinya penting upaya-upaya sumber daya manusia adalah bermuara dari kenyataan bahwa orangorang atau rnanusia merupakan elemen yang selalu ada dalam setiap organisasi (Simamora, 2001).

Menurut Hasibuan (2004) bahwa sumber daya manusia adalah kemampuan terpadu dan daya pikir dengan fisik yang dimiliki seseorang sangat menentukan kecepatan dan ketepatan kualitas hasir pekerjaan, sehingga bila semua jenis dan sumber tingkat pekerja dipadukan dengan baik akan mendapatkan irama kerja yang dinamis dan produktif. 
Menurut Nawawi (2002) memberikan pengertian sumber daya manusia sebagai berikut:

a. Sumber daya manusia adalah manusia yang bekerja di lingkungan organisasi (disebut juga personil, tenaga kerja atau karyawan).

b. Sumber daya manusia adalah potensi sebagai penggerak organisasi dalam mewujudkan eksistensinya.

c. Sumber daya manusia merupakan aset dan berfungsi sebagai modal (non materialdan non finansial).

Berdasarkan pengertian tersebut di atas, maka dapat diartikan bahwa sumber daya manusia merupakan satah satu sumber daya yang terdapat dalam organisasi meliputi semua orang yang melakukan aktifitas. sumber daya manusia adarah tempat menyimpan daya, karena manr.sia memiriki akar, perasaan, keinginan, dorongan, kemampuan, keterampiran, pengetahuan, dan karya. sumber daya manusia merupakan potensi yang memiliki rasio, rasa dan karsa. Potensi tersebut sangat berpengaruh dalam pencapaian tujuan organisasi.

Unsur-unsur sumber daya manusia menurut Gomes (2005) meliputi:

a. Kemampuan-kemampuan (capabilities)

b. Sikap (attitude)

c. Nilai-nilai (Value)

d. Kebutuhan-kebutuhan (needs)

e. Karakter-karakter demografis (penduduk). 
Unsur-unsur tersebut sangat dipengaruhi lingkungan seperti norma-norma, nilai-nilai dalam masyarakat, tingkat pendidikan dan peluangpeluang yang tersedia. unsur tersebut akan mempengaruhi peranan.dan perilaku pengelola dalam organisasi, sebaliknya peranan dan perilaku pengelola mempengaruhi unsur-unsur sumber daya manusia.

Berdasarkan beberapa pendapat tersebut di atas, maka konsep sumber daya manusia cukup menjadi landasan teoritis dan konseptual untuk mengkaji masalah-masalah sumber daya manusia atau tenaga kerja lebih lanjut, terutama dalam hal kemampuan karyawan dalam meningkatkan kinerjanya.

\section{Pengertian Manajemen Sumber Daya Manusia}

Manajemen sumber daya manusia merupakan bagian dari manajemen keorganisasian yang memfokuskan diri pada unsure sumber daya manusia serta pencapaian tujuan organisasi. Tugas manajemen sumber daya manusia adalah untuk mengetola unsur manusia secara baik agar diperoleh tenaga kerja yang puas akan pekerjaannya.

Menurut Flippo dalam Handoko (2002), manajemen personalia adalah perencanaan, pengorganisasian, pengarahan dan pengawasan kegiatan-kegiatan pengadaan, pengembangan, pemberian kompensasi, pengintergasian, pemeliharaan dan pelepasan sumber daya manusia agar tercapai berbagai tujuan individu, organisasi dan masyarakat.

Handoko (2003) mendefinisikan manajemen sumber daya manusia adalah penarikan, seleksi, pengembangan, pemeliharaan dan 
penggunaan sumber daya manusia untuk mencapai baik tujuan indivdu maupun organisasi. Sedangkan menurut Umar (2003), manaiemen sumber daya manusia merupakan bagian dari manajemen keorganisasian yang memfokuskan diri pada unsur sumber daya manusia. Manajemen sumber daya manusia bertugas untuk mengelola unsur manusia secara baik agar diperoleh tenaga kerja yang puas akan pekerjaannya.

Cushway (1996), mendefenisikan manajemen sumber daya manusia sebagai rangkaian strategi, proses, dan aktivitas yang didesain untuk menunjang tujuan perusahaan dengan cara mengintegrasikan kebutuhan perusahaan dan individu. Untuk lebih jelasnya mengenai letak manajemen sumber daya manusia dalam hubungan dengan aktivitr.s organisasi yang lain dapat dilihat pada gambar. Pada gambar tersebut terrihat bahwa strategi sumber data manusia mempengaruhi struktur organisasi yang mana berperandalam manajemen pengupahan (kompensasi) dan hubungan antar karyawan untuk menghasirkan output yang sesuai dengan tujuan organisasi- Sehingga yang ditekankan dalam penulisan ini adalah bahwa manajemen kinerja, peratihan dan pengembangan, manajemen pengupahan (kompensasi) merupakan faktor yang paling menentukan dalam peningkatan kinerja sumber daya manusia untuk mencapai produktivitas karyawan yang tinggi, sesuai yang diharapkan oleh tujuan organisasi tersebut. 


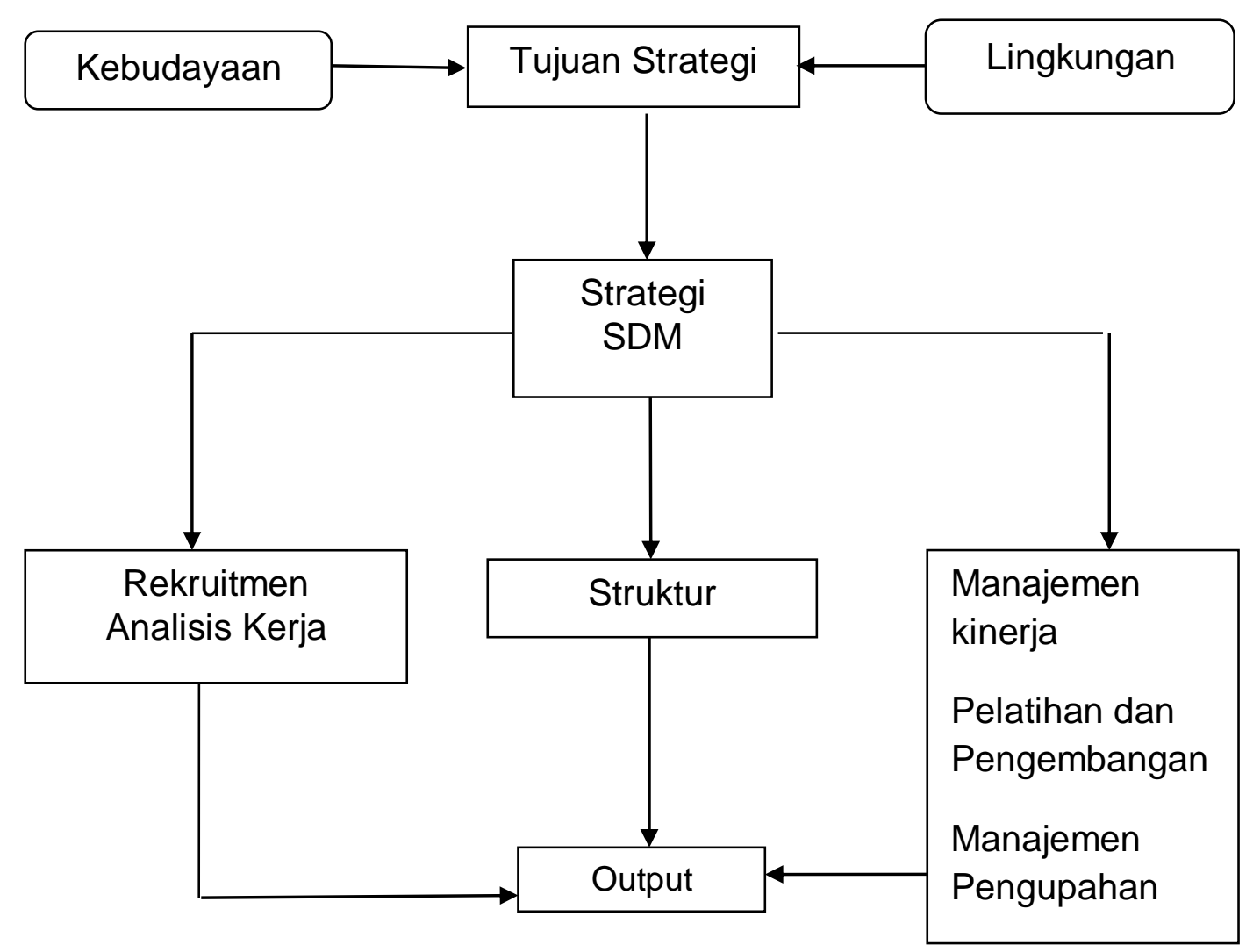

Gambar 1. Proses Manajemen Sumber Daya Manusia menurut Cushway

Manajemen sumber daya manusia yang efektif berhubungan dengan bentuk dan karakter fungsi sebuah organisasi. Dimana aktivitas utamanya adalah mendapatkan sumberdaya, mengelola sumberdaya, dan pemutusan sumberdaya. Manajemen sumberdaya manusia dapat meningkatkan efektivitas manajemen sumber daya manusia dengan menggunakan pendekatan empat rangkah yaitu diagnosis permasalahan, evaluasi praktik yang berjalan, desain sistem manajemen sumberdaya manusia dan implementasi sistem (Simamora, 2001).

Berdasarkan beberapa uraian di atas, dapat disimpurkan bahwa manajemen sumber daya manusia atau biasa disebut manajemen 
personalia adalah pengakuan terhadap pentingnya satuan tenaga kerla organisasi sebagai sumberdaya manusia yang vital bagi pencapaian tujuan-tujuan organisasi dan pemanfaatan berbagai fungsi dan kegiatan manajemen untuk menjamin bahwa tenaga kerja atau sumber daya manusia digunakan secara efektif dan bijak agar bermanfaat bagi individu, organisasi dan masyarakat.

Salah satu tugas dari manajemen sumber daya manusia adalah pengelolaan dan pengembangan sumber daya manusia karena manusia merupakan unsur terpenting daram semua organisasi. Keberhasilan organisasi mencapai tujuan dan sasaran serta kemampuan menghadapi tantangan internar dan ekstemal sangat dipengaruhi oleh kemampuan mengembangkan sumber daya manusia dengan cara setepat-tepatnya.

\section{Peranan Manajemen Sumber Daya Manusia}

Sumber daya manusia merupakan faktor utama dalam proses pembangunan. Peran serta sumber daya manusia dalam pembangunan bukan saja hanya aktif melainkan kesadaran yang dimilikinya tanpa dikendalikan sudah aktif, artinya bukan karena dipaksa dan itulah yang sebenarnya hakikat peran serta sumber daya manusia dalam pembangunan yang diharapkan.

Seiring dengan pentingnya sumber daya manusia, maka perlu upaya untuk mengembangkan peningkatan kualitas sumber daya manusia. Proses administrasi sangat dipengaruhi oleh manajemen 
sumber daya manusia. Menurut Fathoni (2006), ada empat macam klasifikasi sumber daya manusia, yaitu:

a. Manusia atau orang-orang yang mempunyai kewenangan untuk menetapkan, mengendalikan, dan mengarahkan pencapaian tujuan yang disebut administrator.

b. Manusia atau orang-orang yang mengendalikan dan memimpin usaha agar proses pencapaian tujuan yang dilaksanakan dapat tercapai sesuai dengan rencana disebut manajer.

c. Manusia atau orang-orang yang memenuhi syarat tertentu, diangkat langsung melaksanakan pekerjaan sesuai dengan bidang tugasnya masing-masing atau jabatan yang dipegangnya.

Peranan administrasi sangat menentukan dalam kelangsungan hidup suatu organisasi. Namun ada yang lebih menentukan lagi yaitu manusianya. Baik buruknya administrasi sangat tergantung pada sumber daya manusia yang dimilikinya dan manakala kualitas sumber daya manusia yang dimiliki baik, maka proses administrasi akan berjalan dengan baik pula serta tujuan organisasi dapat tercapai sesuai yang diharapkan.

Fungsi manajemen sumber daya manusia menurut (Fathoni, 2006), terdiri atas 2 (dua), yaitu: 1) Fungsi manajerial meliputi: perencanaan (planning), pengorganisasian (organizing),pengarahan (directioning), pengendalian (controlling); dan 2) Fungsi operasional yang meliputi: pengadaan tenaga kerja, pengembangan, kompensasi, pengintegrasian, pemeliharaan dan pemutusan hubungan kerja. 
Peranan manajemen sumber daya manusia dalam pembangunan dapat dibagi dalam dua kelompok, yaitu:

a) Manajemen sumber daya manusia aparatur, mempunyai posisi yang sangat penting,.karena para aparatur melaksanakan fungsi sebagai perumus, perencanaan, pelaksana, pengendali, maupun yang mengevaluasi pembangunan. sebagai kunci manajemen sumber daya manusia harus mempunyai kriteria: bersih, disiplin, berwibawa, dalam melaksanakan selalu memperhitungkan efektivitas dan efisiensi kerja, tanpa manajemen sumber daya manusia maka pembangunan tidak akan membawa hasil yang baik.

b) Manajemen sumber daya manusia masyarakat, juga memegang posisi yang sangat penting karena tanpa partisipasi mereka tidak akan membawa hasil, dan setiap pembangunan yang dilakukan oleh pemerintah sasarannya adalah untuk memberikan kesejahteraan yang lebih baik kepada masyarakat.

Dalam perencanaan sumber daya manusia, yang menjadi fokus perhatian ialah langkah-langkah tertentu yang diambil oleh manajemen guna lebih menjamin bahwa bagi organisasi tersedia tenaga kerja tepat untuk menduduki berbagai kedudukan, jabatan dan pekerjaan yang tepat pada waktu yang tepat. Kesemuanya dalam rangka pencapaian tujuan dan berbagai sasaran yang telah dan akan ditetapkan. Keberhasilan organisasi mencapai tujuan sangat ditentukan oleh kemampuan mengelola sumber daya manusia. 
Peranan sumber daya manusia sebagai sebuah faktor utama yang menggerakkan roda operasional perusahaan, untuk mencapai tujuan perusahaan harus selalu dikelola dengan baik, agar proses pencapaian tujuan perusahaan dapat berjalan dengan lancar. Didalam proses pengelolaan tersebut maka setiap individu yang hkerja di perusahaan mendapatkan imbalan yang dapat berupa upah sebagai balas jasa untuk mencapai tujuan perusahaan.

\section{B. Kinerja Karyawan}

\section{Pengertian Kinerja}

Kinerja karyawan mengacu pada prestasi seseorang yang diukur berdasarkan standar atau kriteria yang ditetapkan oleh perusahaan. Pengelolaan untuk mencapai kinerja sumber daya manusia tinggi dimaksudkan guna meningkatkan perusahaan secara keseluruhan. Kinerja sebenarnya merupakan konsep yang sangat kompleks, baik definisi maupun pengukurannya yang sering menjadi tantangan bagi peneliti teori manajemen dan perilaku organisasi, karena bersifat multidimensional. Sehingga pengukuran kinerja hendak menginteraksikan dimensi pengukuran yang beragam.

Istilah kinerja berasal dari kata job pefformance atau actual performane (kinerja atau prestasi nyata) yang berkaitan dengan segala aktivitas dalam suatu organisasi kerja. pengertian kinerja oleh Muhlis (2005), adatah hasil kerja secara kualitas, kuantitas, efisiensi dan efektif 
yang dicapai seorang karyawan dalam melaksanakan tugasnya sesuai dengan tanggung jawab yang diberikan kepadanya. Lebih lanjut Anwar (2000), mengemukakan kinerja adalah hasil kerja yang dapat dicapai oreh seseorang atau sekelompok orang dalam suatu organisasi, sesuai dengan wewenang dan tanggungjawab masing-masing daram rangka upaya mencapai tujuan organisasi bersangkutan secara regar dan tidak meranggar hukum serta sesuai dengan moral dan etika.

Hasibuan (2002) menyatakan bahwa secara sederhana kinerja adalah apa yang dikerjakan atau tidak dikerjakan oleh karyawan. Kinerja adalah suatu hasil kerja yang dicapai seseorang dalam melaksanakan tugas-tugas yang dibebankan kepadanya yang didasarkan atas kecakapan, pengalaman, dan kesungguhan serta waktu. Kinerja ini adalah gabungan dari tiga faktor penting, yaitu kemampuan dan minat seseorang pekerja, kemampuan dan penerimaan atas penjelasan delegasi tugas dan peran, serta tingkat motivasi seoran pekerja. Semakin tinggi ketiga faktor di atas maka semakin besar kinerja karyawan yang bersangkutan.

Kinerja adalah hasil kerja secara kualitas dan kuantitas yang dicapai oleh seseorang dalam melaksanakan tugasnya sesuai dengan tanggung jawab yang diberikan kepadanya (Mangkunegara, 2005). Secara umum dapat dikatakan bahwa kinerja (performance) merupakan wujud atau keberhasilan pekerjaan seseorang atau organisasi dalam mencapai tujuannya.

Menurut Robbins (2007) bahwa ada tiga kriteria kinerja yang paling umum, yaitu: hasil kerja perorangan, perilaku dan sifat. Jika 
mengutamakan hasil akhir, lebih dari sekedar alat, maka pihak manajemen harus mengevaluasi hasil kerja dari seorang pekerja. Dengan menggunakan hasil kerja, seorang manajer perencana dapat menentukan kriteria untuk kuantitas yang diproduksi, sisa yang dihasilkan, dan biaya per unit produksi.

Betris (2002), menyatakan kinerja adalah kumpulan aktivitas kerja yang maju dan mendorong karyawan untuk mengaKualisasikan aktivitasnya secara optimar untuk menghasilkan hasil kerja optimal, dan menjadi standar penitaian bagi pimpinan. Selanjutnya Sedarmayati (2009) mengemukakan bahwa kegiatan yang paling lazim dinilai dalam organisasi adalah kinerja seseorang, yaitu: bagaimana ia melakukan segala sesuatu yang berhubungan dengan suatu jabatan, pekerjaan, atau peranan dalam organisasi. Kinerja berarti prestasi kerja, pelaksanaan kerja, pencapaian kerja atau hasil kerja untuk penampilan kerja. Pengertian kinerja tersebut menunjuk pada hasil pelaksanaan pekerjaan karyawan. Dengan demikian, pencapaian hasil kerja yang baik berarti menunjukkan kinerja karyawan yang sudah baik dan berlaku sebaliknya.

Berdasarkan pendapat di atas, maka dapat disimpulkan bahwa kinerja adalah hasil dari pelaksanaan pekerjaan karyawan kepada organisasi dimana ia bekerja, dan jika diserahi tugas dan tanggung jawab mempunyai kemampuan, skill dan motivasi tinggi, tentunya akan menyumbangkan kinerja bagi perusahaan. Jadi, untuk mengupayakan terwujudnya optimarisasi kinerja bagi karyawan, maka yang pertama dan utama adalah rekruitmen dan pelatihan, perencanaan kerja, kemudian 
komunikasi dan kebijakan lain seperti memberikan motivasi yang dapat mengikat secara moralitas, dan promosi yang obyektif sesuai karier dan prestasi kerjanya.

\section{Penilaian Kinerja}

Penilaian kinerja adalah kegiatan manajer untuk mengevaluasi perilaku dan prestasi kerja karyawan serta menetapkan kebijaksanaa selanjutnya. Penialaian perilaku yaitu menilai kesetiaan, kejujuran, kepemimpinan, kerjasama, loyalitas dedikasi dan partisipasi karyawan. Menilai perilaku ini sulit karena tidak ada standar fisiknya, sedangkan untuk penilaian hasil kerja relative lebih mudah karena ada standar fisik yang dapat dipakai sebagai tolak ukurnya, seperti satuan meter, liter, kilogram, dan lain-lain.

Menurut Paryaman (2001) dalam kehidupan suatu organisasi, ada beberapa asumsi tentang perilaku manusia sebagai sumber daya manusia yang mendasari pentingnya penilaian kinerja karyawan dan asumsi tersebut antara lain :

a. Setiap orang ingin memiliki peluang untuk mengembangkan kemampuan kinerjanya sampai tingkat maksimal.

b. Setiap orang ingin mendapatkan penghargaan apabila ia dinilai melaksanakan tugasnya dengan baik.

c. Setiap orang ingin mengetahui secara pasti tentang karir yang akan diraihnya apabila dapat melaksanakan tugasnya dengan baik. 
d. Setiap orang ingin mendapatkan perlakuan yang objektif dan penilaian atas dasar prestasi kerja.

e. Setiap orang pada umunya tidak hanya melakukan kegiatan yang sifatnya rutin.

Dipenuhi berbagai keinginan karyawan tersebut yang perlu dilakukan organisasi yang menginginkan karyawan dengan kinerja yang baik. Penilaian kinerja merupakan suatu proses organisasi untuk menilai kinerja pegawainya. Tujuan dilakukannya penilaian kinerja secara umum adalah untuk memberikan umpan balik kepada karyawan dalam upaya memperbaiki kinerjanya dan meningkatkan produktivitas pegawai, khususnya yang berkaitan dengan kebijaksanaan terhadap karyawan seperti: untuk tujuan promosi, kenaikan gaji, pendidikan dan latihan.

Tujuan dilakukannya penilaian kinerja karyawan adalah sebagai berikut (Martoyo, 2007):

a. Mengidentifikasi karyawan yang membutuhkan pendidikan dan latihan.

b. Menetapakan kenaikan gaji ataupun upah karyawan.

c. Menetapkan kemungkinan pemindahan karyawan ke penugasan baru.

d. Menetapkan kebijaksanaan baru dalam rangka reorganisasi.

e. Mengidentifikasi karyawan yang akan dipromosikan ke jabatan tinggi.

Terdapat beberapa tujuan penting dari program penilaian kinerja individu yang tidak dapat dicapai dengan metode lain. Menurut Simamora (2001) bahwa tujuan pokok sistem penilaian kualitas kinerja adalah menghasilkan informasi yang akurat tentang perilaku dan kinerja anggota- 
anggota organisasi. semakin akurat informasi yang dihasilkan oleh sistem penilaian kualitas kinerja, semakin besar potensi nilainya bagi organisasi.

Menurut Pangabean (2004), bahwa penilaian kuaritas kinerja dilakukan untuk memperoreh informasi yang berguna daram pengambilan keputusan berkaitan dengan kegiatan manajemen sumber daya manusia, seperti: perencanaan penarikan dan seleksi, pengembangan sumber daya manusia, perencanaan dan pengembangan karir, program kompensasi, promosi, pensiun dan pemecatan.

Menurut Rivai (2008), bahwa penilalaian kinerja didasarkan pada dua alasan pokok, yaitu: 1) manajer memerlukan evaluasi yang obyektif terhadap kinerja karyawan pada masa lalu yang digunakan untuk membuat keputusan di bidang sumber daya manusia di masa akan datang; dan 2) manajer memerlukan alat yang memungkinkan untuk membantu karyawan untuk memperbaiki kinerjanya, merencanakan pekerjaan, mengembangkan kemampuan dan keterampilan untuk mengembangkan karier dan memperkuat kualitas hubungan antar manajer yang bersangkutan dengan karyawannya.

Jadi, dengan penilaian kualitas kinerja dapat diketahui kinerja seseorang karyawan dimana terdapat kelebihan-kelebihan maupun kekurangan-kekurangan yang dimilikinya. Bagi mereka yang memiliki prestasi kerja tinggi memungkinan dirinya untuk diberikan promosi. sebaliknya, karyawan yang kualitas kinerjanya rendah dapat diperbaiki dengan memindahkan kejabatan yang sesuai dengan kecakapan atau melalui pendidikan dan latihan dalam rangka pengembangan karyawan. 
Kinerja dinilai berdasarkan hasil pencapaian kerja sesuai kuantitas, efesiensi dan efektivitas kerja dalam memperoleh realisasi kerja, baik dalam negeri maupun asing. Berikut penilaian kinerja diformulasikan menurut Davis (2005), kinerja adalah kumpulan dari serangkaian hasil kerja menurut, kualitas, efisiensi dan efektivitas kerja dalam mencapai tujuan. Formulasi tersebut sebagai berikut:

Pefformances = quantity, quatity, efecient and effectivity

Formulasi ini menunjukkan bahwa hasil kerja yang dicapai oleh individu sumber daya manusia sangat ditentukan dari pencapaian kuantitas kerja yang banyak, kuaritas kerja yang bermutu, efektivitas kerja yang tepat sasaran dan efektivitas kerja sesuai dengan manfaat yang dicapai.

Kinerja karyawan dapat diukur berdasarkan penilaian pimpinan atas pelaksanaan pekerjaan karyawan yang menjadi standar bagi suatu instansi atau departemen untuk menilai aktivitas yang dilakukan karyawan. Penilaian kinerja merupakan suatu mekanisme yang baik untuk mengendalikan orang dan sekaligus mekanisme untuk memastikan karyawan pada tiap tingkatan mengerjakan tugas-tugasnya menurut cara yang diinginkan oleh para pemimpinnya (Musanef, 2001).

Menurut Setyanto (2002), penilaian atau pengukuran kinerja untuk organisasi mengacu kepada hasil kerja individu yang ditunjukkan sesuai realisasi yang dicapai dengan membandingkan target kerja yang ditetapkan. Apabila melampaui target yang telah ditetapkan, maka hasil 
kerja menunjukkan kinerja yang tinggi. Sebaliknya, apabila realisasi kerja tidak melampaui target yang ditetapkan maka kinerjanya rendah.

Penilaian kinerja dinilai sebagai konstribusi karyawan kepada organisasi selama periode waktu tertentu. Umpan balik kinerja individu memungkinkan karyawan mengetahui seberapa baik mereka bekerja jika dibandingkan dengan standar-standar organisasi. Di dalam organisasi modern, penilaian kinerja memberikan mekanisme penting manajemen untuk digunakan dalam menjelaskan tujuantujuan dan standar-standar kinerja dan memotivasi kinerja individu di waktu berikutnya. Penilaian kinerja memberikan basis bagi keputusan-keputusan yang mempengaruhi gaji, promosi, pemberhentian, pelatihan, dan kondisi kepengawaian.

Menurut Bernadin dan Russel (2001:243), di dalam menilai kinerja ini terdapat beberapa kriteria yang dapat dilihat, antara lain:

1. Quality, yaitu tingkat hasil yang dicapai oleh seorang karyawan dalam menyelesaikan suatu bekerja.

2. Quantity, yaitu jumlah pekerjaan yang dihasilkan oleh seorang karyawan dalam bekerja.

3. Timetinness, yaitu tingkat ketepatan waktu yang dicapai oleh seorang karyawan dalam melaksanakan aktivitas kerjanya, sehingga dengan demikian dia dapat melakukan aktivitas lainnya.

4. Cosf-Efleoveness, yaitu suatu tingkat efesiensi dalam menggunakan waktu dalam bekerja.

5. Need for Supervision, yakni suatu tingkat kemandirian dalam bekerja. 
6. Impersonal impact, dampak hubungan antar pribadi baik antar sesama rekan kerja maupun antar atasan dan bawahan (neet working).

Berbagai pengertian dari penilaian kinerja yang dikemukakan oleh para ahli, antara lain: Simamora (2001) mengemukakan bahwa penilaian kinerja (performance appraisal) adalah proses yang berkenaan dengan organisasi dalam mengevaruasi pelaksanaan kinerja individu. Selanjutnya Musanef (2001), mendefenisikan penilaian kinerja adalah menilai rasio hasil kinerja dengan standar kualitas maupun kuantitas yang dihasilkan oleh karyawan.

Sikula dalam Anwar (2000), menjelaskan bahwa penilaian kinerja merupakan evaluasi yang sistematis dari pekerjaan karyawan dan potensi yang dapat dikembangkan untuk diberi penilaian sesuai standar kerja yang dapat dikembangkan untuk diberi penilaian sesuai standar kerja yang ditetapkan oleh suatu organisasi.

Berdasarkan pendapat di atas, penilaian kinerja adalah suatu proses penilaian hasil kerja karyawan yang dilakukan pimpinan organisasi secara sistematik berdasarkan tugas yang diberikan kepadanya menurut reputasi standar kinerja yang dicapainya. Penilaian kinerja berfaedah tidak hanya untuk mengevaluasi kerja karyawan tetapi iuga untuk mengembangkan dan memotivasi karyawan agar bisa memenuhi standar kinerja yang telah ditetapkan.

Sesungguhnya semua organisasi memiliki sarana formal dan informal untuk menilai kinerja karyawannya. penilaian kinerja didefinisikan 
sebagai prosedur apa saja yang meliputi: (1) penetapan standar kerja, (2) penilaian kinerja aktual karyawan dalam hubungan dengan standarstandar ini, dan (3) memberikan umpan balik kepada karyawan dengan tujuan untuk meningkatkan kinerja atau terus berkinerja yang lebih tinggi.

Berdasarkan beberapa pendapat di atas, maka dapat disimpulkan penilaian kinerja adalah proses kegiatan organisasi yang mernberikan peniraian peraksanaan kerja individu dengan jaran menilai kontribusi karyawan terhadap organisasi kerja sesuai dengan kontinuitas waktu kerja yang diraksanakannya. Jadi, penilaian kinerja karyawan adalah penilaian pimpinan untuk memastikan bahwa karyawan telah bekerja sesuai standar waktu dan metode kerja yang memberikan nilai kepuasan sesuai penilaian kinerja kerja yang diberikan.

\section{Faktor-Faktor Yang Mempengaruhi Kinerja Karyawan}

Faktor-faktor yang mempengaruhi pencapaian kinerja adalah kemampuan (abitity) dan motivasi (motivation) Hal ini sesuai pendapat Keith Davis datam Mangkunegara (2005), merumuskan bahwa:

$$
\begin{array}{ll}
\text { Human performance } & =\text { Ability } \times \text { Motivation } \\
\text { Motivation } & =\text { Attitude } \times \text { Situation } \\
\text { Ability } & =\text { Knowledge } \times \text { Skill }
\end{array}
$$

Adapun uraiannya adalah sebagai berikut :

1. Faktor Kemampuan (ability)

Secara psikologis, kemampuan (abitity) terdiri dari kemampuan potensi (IQ) dan kemampuan reality (knowledge + skill).Artinya, pimpinan dan 
karyawan yang memiliki IQ di atas rata-rata (IQ 110-120) apalagi IQ superior, very superior, gifted dan gennius dengan pendidikan yang memadai untuk jabatannya dan terampil dalam nengerjakan pekerjaan sehari-hari, maka akan rebih mudah mencapai kinerja maksimal.

2. Faktor motivasi (motivation)

Motivasi diartikan suatu sikap (attitude) pimpinan dan karyawan terhadap situasi kerja (situation) di lingkungan organisasinya. Mereka yang bersikap positif (pro) terhadap situasi kerjanya akan menunjukkan motivasi kerja tinggi dan sebaliknya jika mereka bersikap negatif terhadap situasi kerjanya akan menunjukkan motivasi kerja yang rendah. Situasi kerja yang dimaksud mencakup antara lain: kedisiplinan, lingkungan kerja, kebijakan pimpinan termasuk promosi jabatan, hubungan kerja, pora kepemimpinan kerja dan kondisi kerja.

Selanjutnya menurut simamora daram Mangkunegara (2005), kinerja (performance) dipengaruhi oleh tiga faktor, yaitu:

1. Faktor individual, meliputi: kemampuan dan keahlian, latar belakang, dan demografi.

2. Faktor psikologis, meliputi: komunikasi, persepsi, attitude, personarity, pembelajaran, dan motivasi.

3. Faktor organisasi, meliputi: sumber daya, kepemimpinan, penghargaan, perencanaan, struktur, dan job design.

Menurut A. Dare Timpre datam Mangkunegara (2005), faktor-faktor kinerja terdiri dari faktor internal dan faktor eksternal. Faktor internal yaitu: faktor yang dihubungkan dengan sifat-sifat seseorang. Misalnya, kinerja 
seseorang baik disebabkan karena mempunyai kemampuan tinggi dan seseorang itu tipe pekerja keras, disiplin, bertanggungjawab, sedangkan seseorang mempunyai kinerja jerek disebabkan orang tersebut mempunyai kemampuan rendah dan tidak

Kinerja individu adalah hasil kerja karyawan baik dari segi kualitas maupun kuantitas berdasarkan standar kerja yang telah ditentukan. Kinerja individu ini akan tercapai apabila didukung oleh atribut individu, upaya kerja (work effort) dan dukungan organisasi. Indikator pengukuran kinerja karyawan dalam penelitian ini mengacu pada teori yang dikemukakan oleh Bernadin dan Russel (2001), meliputi: kualitas hasil kerja, kuantitas hasil kerja, efektivitas kerja, efisiensi kerja, dan kemandirian dalam bekerja.

\section{Perencanaan}

Dalam ilmu menajemen menjelaskan bahwa salah satu fungsi pokok manajemen adalah perencanaan, di mana dalam ilmu manajemen menjelaskan bahwa fungsi pokok manajemen terdiri dari perencanaan, koordinasi, pelaksanaan, pengawasan dan evaluasi. Perencanaan merupakan salah satu fungsi pokok manajemen yang pertama harus dijalankan. Sebab tahap awal dalam melakukan aktivitas perusahaan sehubungan dengan pencapaian tujuan organisasi perusahaan adalah dengan membuat perencanaan (Rivai dan Sagala, 2009).

Definisi perencanaan yang dikemukakan oleh Wahid (2004) bahwa perencanaan merupakan proses penentuan tujuan organisasi 
(perusahaan) dan kemudian menyajikan (mengartikulasikan) dengan jelas strategi-strategi (program), taktik-taktik (tata cara pelaksanaan program) dan operasi (tindakan) diperlukan untuk mencapai tujuan perusahaan secara menyeluruh. Selanjutnya Sritomo (2006) mendefinisikan perencanaan sebagai sebuah proses untuk menetapkan ke arah mana kegiatan harus ditujukan dengan mengidentifikasi segala prasyarat dan kondisi agar bisa sampai ketempat tujuan dengan cara dan usaha yang paling efektif dan efisien.

Menurut Ruky (2003), perencanaan adalah pemikiran rasional berdasarkan fakta-fakta dan atau perkiraan yang mendekat (estimate) sebagai persiapan untuk melaksanakan tindakan-tindakan kemudian. Selanjutnya Siagian (2004) mengemukakan bahwa perencanaan adalah keseluruhan proses pemikiran dan penentuan secara matang daripada hal-hal yang akan dikerjakan di masa yang akan datang dalam rangka pencapaian yang telah ditentukan.

Terry (2005) mengemukakan perencanaan adalah pemilihan dan menghubungkan fakta-fakta, membuat serta menggunakan asumsiasumsi yang berkaitan dengan masa datang yang menggambarkan dan merumuskan kegiatan-kegiatan tertentu yang diyakini diperlukan untuk mencapai suatu hasil tertentu. Selanjutnya Dessler (2001), perencanaan adalah proses dasar yang digunakan untuk memilih tujuan-tujuan dan menguraikan bagaimana cara pencapainnya. Sedangkan Sukirno (2004) mengemukakan perencanaan adalah pemilihan alternatif atau pengalokasian berbagai sumber daya yang tersedia. 
Berdasarkan pengertian di atas, maka perencanaan adalah proses mendefinisikan tujuan organisasi, membuat strategi untuk mencapai tujuan itu, dan mengembangkan rencana aktivitas kerja organisasi. Perencanaan merupakan proses terpenting dari semua fungsi manajemen karena tanpa perencanaan fungsi-fungsi lain dalam pengorganisasian, pengarahan, dan pengontrolan tidak akan dapat berjalan. Rencana dapat berupa rencana informal atau rencana formal. Rencana informal adalah rencana yang tidak tertulis dan bukan merupakan tujuan bersama anggota suatu organisasi. Sedangkan rencana formal adalah rencana tertulis yang harus dilaksanakan suatu organisasi dalam jangka waktu tertentu. Rencana formal merupakan rencana bersama anggota korporasi, artinya, setiap anggota harus mengetahui dan menjalankan rencana itu. Rencana formal dibuat untuk mengurangi ambiguitas dan menciptakan kesepahaman tentang apa yang harus dilakukan.

Perencanaan yang baik sangat ditentukan oleh keberhasilan pelaksanaan proses perencanaan. Wahid (2004) mengemukakan bahwa langkah-langkah dalam menyusun suatu proses perencanaan yang baik adalah sebagai berikut:

b. Penetapan tujuan organisasi

Penetapan tujuan awal organisasi merupakan bagian awal dari proses penyusunan perencanaan. Tujuan organisasi ibarat kompas yang dijadikan arah bagi keputusan dan aktivitas organisasi. Perumusan tujuan harus dibuat sejelas mungkin dan sedapat mungkin bersifat kuantitatif. Sedangkan perumusan tujuan yang bersifat 
kualitatif memiliki kecenderungan dalam salah tafsir dari berbagai pihak atau dapat menimbulkan salah persepsi sehingga memberi kesan adanya pelonggaran di dalam pencapaian tujuan organisasi. Tanpa perumusan tujuan organisasi yang tegas dan jelas maka organisasi akan menghamburkan sumber daya secara berlebihan. Mengenal prioritas akan kekhasan tujuan organisasi akan membuat manajemen dapat menggunakan sumber daya secara efektif dan efisien. Perumusan organisasi sangat penting, baik bagi perusahaan besar maupun perusahaan kecil. Perumusan tujuan organisasi merupakan prioritas pertama atau kedua, dikarenakan penetapan tujuan organisasi merupakan langkah pertama yang sangat esensial di dalam perencanaan, sehingga pemimpin/manajer harus dapat membuat perencanaan yang efektif dan efisien.

Penyebab terjadinya kegagalam dalam merumuskan tujuan organisasi (Hasibuan, 2002) adalah:

a. Keengganan menetapkan alternatif tujuan

Seringkali pemimpin/manajer dihdapkan kepada berbagai keukaran mengakui kenyataan bahwa tidak semua hal dapat dicapai, akibatnya pemimpin/manajer enggan membuat komitmen organisasi kepada satu tujuan karena jika tidak tercapai maka pemimpin/manajer dihadapkan kepada penilaian tidak berhasil.

b. Takut gagal

Pemimpin/manajer yang menetapkan satu tujuan umumnya takut tidak mencapainya (gagal), sehingga pemimpin/manajer sering kali 
merumuskan banyak tujuan yang akan dicapai. Meskipun ada manajer bertipe berani menghadapi resiko akan tetapi umumnya resiko sering kali dihindari sedapat mungkin.

c. Kekurangan pengetahuan tentang organisasi

Pemimpin/manajer akan menetapkan tujuan organisasi yang tepat, jika pemimpin/manajer tidak mempunyai pengetahuan luas tentang organisasi dan unit-unitnya. Setiap bagian (unit) mempunyai keterkaitan yang luas dengan tujuan organisasi secara keseluruhan. Pemimpin/manajer harus mengetahui berbagai karakteristik unit dan organisasi secara keseluruhan agar dengan mudah dapat mengarahkan dan mengelola sarana dan prasarana secara efktif dan efisien

d. Kekurangan pengetahuan akan lingkungan

Pemimpin/manajer di samping mengetahui lingkungan internal organisasi harus mengenal lingkungan eksternal organisasi. Tanpa mengenal lingkungan eksternal organisasi, maka manajemen organisasi akan berjalan secara acak (tak terarah) dan akan mudah terhempas oleh lingkungan eksternalnya. Lingkungan eksternal tersebut meliputi pesaing, pemasok, sponsor, target sasaran, lembaga pemerintah, masyarakat luas, dan sebagainya.

e. Kurang percaya diri

Untuk mempunyai kemantapan terhadap tujuan organisasi, maka pemimpin/manajer dan orang-orangnya harus mempunyai kepercayaan diri yang kuat (self confidence) bahwa ia mampu 
mencapai tujuan yang telah ditetapkan. Jika manajer mempunyai kepercayaan diri yang lemah maka akan senantiasa ragu di dalam melaksanakan tugasnya.

Pemimpin/manajer di dalam merumuskan tujuan organisasi harus memiliki pengetahuan yang memadai agar dapat bekerja secara efektif dan efisien. Pemimpin/manajer yang pengetahuannya kurang memadai di bidang lingkungan eksternal organisasi membutuhkan bantuan di bidang sistem informasi yang cukup memadai yang dapat disediakan dengan berbagai cara yang berbeda-beda. Dalam program pengembangan manajemen organisasi pemimpin akan melakukan kontak informal dari berbagi unit. Kontak informal ini membantu untuk mengetahui berbagai hal yang ada di luar organisasi dan juga meningkatkan kepercayaan diri pemimpin di dalam melaksanakan tugas-tugasnya.

Berbagai kendala atau ketakutan akan kegagalan dapat ditekan serendah mungkin jika organisasi telah mempunyai komunikasi yang baik dan efektif dalam kaitannya dengan penyusunan rencana. Bilamana perencanaan merupakan proses yang mudah dimengerti maka akan lebih mudah mengembangkan tujuannya serta akan memperoleh bantuan di dalam mengembangkan rencana untuk mencapai nilai tujuan. Bilamana teknik pengambilan keputusan dipakai secara meluas maka akan lebih mudah menetapkan alternatif yang diperlukan untuk mencapai tujuan lainnya. Ketakutan akan kegagalan dan kekurangyakinan diri juga dapat diperkecil melalui penataan 
dan penetapan tujuan yang realisitis serta berbagai cara untuk mencapainya (Fathoni, 2006).

Perencanaan secara tidak langsung terkait dengan perubahan dan mengimplementasikan serta mengelola perubahan merupakan bagian tugas yang penting bagi manajemen. Banyak cara yang harus dilakukan oleh manajemen di dalam menghadapi berbagai perlawanan yang dilakukan oleh pihak lain atau bawahan, yaitu:

a. Perlu melibatkan karyawan dan kelompok terkait lainnya termasuk berbagai pihak yang berkepentingan di dalam proses perencanaan.

b. Menyediakan informasi yang memadai bagi karyawan mengenai rencana dan berbagai konsekuensi yang mungkin terjadi agar karyawan mau mengerti kebutuhan akan adanya perubahan manfaat yang diharapkan dan diperlukan bagi implementasi yang efektif dan efisien.

c. Mengembangkan perencanaan yang efektif dan efisien serta implementasi yang efektif dan efisien pula. Catatan penelusuran keberhasilan dalam kepercayaan diri bagi penyusun rencana dan pengakuan rencana baru.

d. Sadar akan dampak perubahan organisasi yang diusulkan dan memperkecil gangguan yang tidak dikehendaki. Jika pengenalan proses manufaktur baru mengarah kepada pemberhentian (pemutusan hubungan kerja), maka pelaksanaan proses baru harus dikaitkan dengan kendala yang ada serta meyakinkan mereka yang berprasangka negatif 
e. Penetapan tujuan dan skala prioritas di awal telah dijelaskan bahwa langkah awal di dalam menyusun rencana harus dimulai dari tujuan. Di dalam menyusun rencana maka pemimpin/manajer atau perencana harus menetapkan skala prioritas dan waktu yang tepat tentang tercapainya tujuan. Di samping itu maka pemimpin/manajer harus menyadari konflik tujuan dan harus pula menyediakan pengukuran tujuan sehingga hasil dari pelaksanaan dapat diukur dan dievaluasi (Gunawan, 2001).

Berbagai aspek yang harus diperhatikan di dalam penetapan tujuan dan prioritas (Nawawi, 2006) meliputi:

a. Skala prioritas tujuan

Skala prioritas adalah urutan kepentingan dari tertinggi sampai terendah. Skala prioritas memegang peranan yang sangat penting sebab skala prioritas ini akan memberikan perhatian yang penuh bagi manajer di dalam mengalokasikan sumber daya yang ada sehingga yang diutamakan adalah yang mempunyai prioritas utama (terpenting). Skala prioritas tujuan organisasi menunjukkan tahapan yang hendak dicapai yang disesuaikan dengan kekuatan, kelemahan, kesempatan dan ancaman organisasi. Karena penetapan skala prioritas merupakan keputusan kebijakan maka umumnya manajer menghadapi kesulitan di dalam merumuskannya, sehingga biasanya disusun tim yang akan membahas skala prioritas tersebut. 
b. Kerangka waktu tujuan

Di dalam kajian analisis studi gerak dan waktu dijelaskan bahwa setiap gerak membutuhkan waktu dan tindakan merupakan kumpulan gerak sehingga tindakan akan lebih banyak waktu yang diperlukan dibandingkan gerak. Dimensi waktu secara tak langsung merujuk pada aktivitas organisasi yang diarahkan oleh berbagai tujuan yang berbeda dan sangat tergantung kepada durasi (penyelesaian) tindakan yang direncanakan. Tujuan jangka pendek dapat dicapai dalam waktu kurang dari satu tahun, sedangkan tujuan jangka menengah dicapai kurang dari 5 tahun, akan tetapi lebih dari satu tahun keterkaitan prioritas dan waktu sangat erat dan keterkaitan itulah maka dapat menetapkan suatu definisi tentang suatu kegiatan atau suatu obyek. Batasan waktu dapat menjadi manajemen berpikir dan bertindak efektif sehingga menghasilkan kinerja yang efektif pula. Dari ukuran (dimensi) waktu maka kinerja organisasi akan dapat diketahui apakah organisasi tersebut telah melakukan tugasnya secara efektif dan efisien. Dalam kaitannya dengan waktu ini pula maka meskipun tujuan organisasi diklasifikasikan kedalam jangka pendek, menengah dan panjang akan tetapi ketiganya sebenarnya mempunyai satu kesatuan yang utuh, karena ketiganya akan saling mempengaruhi. Oleh karena itu, perhatian manajemen suatu organisasi tidak dibenarkan hanya berfokus pada salah satu unsur waktu saja. 
c. Konflik di antara tujuan

Organisasi akan berhubungan dengan berbagai pihak yang berkepentingan dan berbagai pihak yang berkepentingan atas organisasi mempunyai berbagai otoritas yang berbeda-beda dari mulai lemah sampai yang kuat. Yang kuat mempunyai pengaruh yang besar bagi perkembangan dan kinerja prganisasi. Karena benyaknya pihak yang berkepentingan maka tidak menutup kemungkinan akan terjadi konflik tujuan organisasi. Oleh karena itu, manajemen dituntut untuk membuat keputusan yang bijak agar pihak yang berkepentingan tidak merasa dikecewakan. Meskipun dengan sebenarnya terdapat tujuan organisasi umumnya tidak akan menolaknya dan manajemen harus mempertimbangkan berbagai kepentingan dan pemusatan dari berbagai kelompok berkepentingan yang berbeda-beda.

d. Pengukuran tujuan

Tujuaan organisai harus dapat dimengerti dan diterima guna membantu manajemen agar dapat mencapainya. Dalam kenyataan, banyak orang percaya bahwa tujuan spesifik yang mudah diukur akan dapat meningkatkan kinerja, baik bagi individu maupun bagi organisasi. Dalam kaitannya dengan pengukuran ini yang harus diperhatikan adalah di bidang apa yang akan diukur dan apa jenis pengukurannya serta metode apa yang digunakan di dalam pengukuran. Di dalam praktiknya ternyata kinerja 
manajemen yang efektif memerlukan penetapan pengukuran tujuan di berbagai bidang fungsi kegiatan.

2. Mendefinisikan situasi sekarang

Suatu organisasi dapat saja gagal mencapai tujuan jangka pendeknya atau berhasil mencapainya karena dipengaruhi oleh berbagai faktor. Hal ini tentu sangat terkait dengan situasi sekarang atau situasi yang sedang berjalan. Pemimpin/manajer harus menyadari bahwa situasi dan keadaan sekarang sangat dipengaruhi oleh situasi dan kondisi sebelumnya dan posisi sekarang sangat dipengaruhi oleh situasi dan kondisi yang akan datang. Oleh karena itu, mengenai situasi dan kondisi sekarang sangat penting artinya bagi seorang pemimpin/manajer termasuk dari data masa lalu sampai pada posisi sekarang merupakan petunjuk atau sinyal seberapa jauh perencanaan yang telah dilakukan telah berjalan efektif dan efisien. Oleh karena itu, pengalaman di dalam menyususn perencanaan sangat penting untuk masa yang akan datang.

3. Mengenal dukungan dan kendala

Setiap penyususn rencana sebaiknya mengenal apa saja yang akan mendukung perencanaan yang disusun dan kendala apa saja yang merintanginya. Dengan mengenal dukungan dan kendala maka pemimpin/manajer akan dapat mengantisipasi sedini mungkin tentang berbagai hal yang terjadi dari kemungkinan yang terjelek (terburuk) sampai kepada kemungkinan terbaik. Sebaiknya, pemimpin/manajer lebih memusatkan perhatiannya pada berbagai kemungkinan terjelek 
daripada memusatkan kepada kemungkinan terbaik. Memahami berbagai kemungkinan terjelek akan menyadarkan pemimpin/manajer untuk bertindak hati-hati, sedangkan memperhatikan kemungkinan terbaik akan memotivasi pemimpin/manajer di dalam melaksanakan tugasnya. Segala kemungkinan terjelek dan terbaik harus dapat dicantumkan di dalam penyusunan perencanaan. Pemimpin/manajer dapat menggunakan pendekatan terendah dan tertinggi (high and lawa point method) atau menggunakan teerjelek dan terbaik (the worts and the best method).

4. Mengembangkan premis peerencanaan

Premis adalah asumsi tentang lingkungan di mana organisasi itu berada. Lingkungan organisasi yang sedang berubah akan sangat mempengaruhi aktivitas organisasi, memaksa adaptasi operasi yang berjalan dan perlu peninjauan tentang segala tatanan yang ada dalam organisasi. Pemimpin/manajer yang ahli akan senantiasa berusaha memanfaatkan sumber informasi yang tersedia guna mengantisipasi dan merencanakan metode yang tepat untuk disesuaikan dengan segala kemungkinan yang akan terjadi. Oleh karena itu, sebelum pemimpin/manajer menyusun rencana sebaiknya pemimpin/manajer telah membuat peramalan yang terkait dengan rencana yang akan di susun. Peramalan akan sangat membantu pemimpin/manajer di dalam menyusun rencana sebab peramalan akan memberikan sinyal dini bagi manajer. 
5. Mengembangkan metode pengawasan operasi rencana

Sebelum perencanaan dilaksanakan maka perlu menetapkan metode pengawasan terlebih dahulu. Di dalam metode pengaawasan telah dperhitungkan berbagai permasalahan dan kendala di lapangan serta berbagai cara menanggulanginya. Jika metode pengawasan tidak dipersiapkan terlebih dahulu maka terjadi permasalahan atau kendala di lapangan, di mana metode pegawasannya akan lebih cenderung kurang sistematis dan bersifat acak. Pengawasan akan melibatkan analisis berkelanjutan dan pengukuran operasi aktual terhadap standar yang dikembangkan dan dirumuskan di dalam proses perencanaan (Nawawi, 2006).

Berdasarkan uraian di atas dapat disimpulkan bahwa pada intinya perencanaan dibuat sebagai upaya untuk merumuskan apa yang sesungguhnya ingin dicapai oleh sebuah organisasi atau perusahaan serta bagaimana sesuatu yang ingin dicapai tersebut dapat diwujudkan melalui serangkaian rumusan rencana kegiatan tertentu. Oleh karena itu, langkah-langkah yang ditempuh dalam proses perencanaan menjadi indikator yang digunakan dalam mengukur variabel perencanaan yakni: penetapan tujuan organisasi yang jelas, mendefinisikan situasi sekarang untuk mencapai keberhasilan, mengenal dukungan dan kendala untuk mengatasi persoalan kerja, mengembangkan premis perencanaan dengan membuat peramalan rencana, dan mengembangkan metode pengawasan operasi rencana yang efektif. Kelima indikator diyakini mampu membentuk variabel perencanaan dalam mendukung peningkatan kinerja karyawan. 


\section{Komunikasi}

Manusia adalah makhluk sosial yang tergantung, mandiri dan saling terkait dengan orang lain di lingkungannya. Satu-satunya alat untuk dapat mencapai hubungan yang dekat dengan orang lain di lingkungannya adalah komunikasi, baik melalui bahasa verbal maupun bahasa non verbal.

Tidak ada kelompok yang dapat bertahan tanpa komunikasi, yaitu pemindahan maksud antara anggota-anggotanya. Informasi dan ide-ide dapat disampaikan melalui penyampaian arti dari satu orang kepada orang lain. Komunikasi bagaimanapun adalah lebih dari sekedar menyampaikan arti. Komunikasi juga harus dapat dipahami, oleh karenanya komunikasi harus menyertakan keduanya, yaitu penyampaian dan pemahaman dari sebuah arti (Mulyana, 2004).

Komunikasi dalam organisasi menjadi hal penting untuk menciptakan kesamaan pemahaman atas informasi yang disampaikan satu sama lain. Komunikasi dapat menciptakan kepuasan bagi orangorang yang melakukannya, seperti yang diungkapkan Dale Carnegie dalam Nurdin (2000), kepuasan bisnis, sosial, dan pribadi tergantung pada kemampuan seseorang berkomunikasi dengan jelas pada orang lain, apa pekerjaannya, apa yang diinginkannya, dan apa yang dipercayainya.

Mulyana (2004) mengemukakan bahwa komunikasi adalah proses berbagai makna melalui perilaku verbal dan non verbal. Segala perilaku dapat disebut komunikasi jika melibatkan dua orang atau lebih. Komunikasi organisasi dapat dinyatakan sebagai penunjukan atau 
penafsiran pesan diantara unit-unit komunikasi yang merupakan bagian dari suatu organisasi tertentu.

Robbins (2007) mengemukakan komunikasi merupakan sebuah pentransferan makna maupun pemahaman makna kepada orang lain dalam bentuk lambang-lambang, simbol, atau bahasa-bahasa tertentu sehingga orang yang menerima informasi memahami maksud dari informasi tersebut. Selanjutnya menurut Rogers dalam Cangara (2006), komunikasi adalah proses di mana suatu ide dialihkan dari sumber kepada satu penerima atau lebih, dengan maksud untuk mengubah tingkah laku mereka.

Menurut Gitosudarmo dan Mulyono (2003), komunikasi berperan dalam tiga jenis peran manajerial, yaitu:

a. Berperan antar pribadinya, manajer bertindak sebagai simbol dan pemimpin serta sebagai koordinator unit organisasinya. Dia akan berinteraksi dengan bawahan, pelanggan, pemasok dan rekan setingkatnya dan juga dengan atasannya.

b. Berperan informasionalnya, manajer akan selalu mencari informasi dari rekan setingkat, bawahan, pemasok dalam organisasinya, serta kontak pribadi lainnya mengenai segala upaya yang dapat mempengaruhi pekerjaan dan tanggung jawabnya.

c. Berperan keputusannya, manajer menangani gangguan dalam unit organisasinya dan menangani pengalokasian sumber daya kepada bagianbagian yang membutuhkannya. Keputusannya mungkin diambil sendiri atau melibatkan bawahannya. 
Komunikasi dalam organisasi sangatlah penting, dimana organisasi merupakan suatu kesatuan atau perkumpulan yang terdiri atas orangorang atau bagian-bagian yang di dalmnya terdapat aktivitas kerja sama berdasarkan aturan-aturan untuk mencapai tujuan bersama. Beberapa penelitian mengungkapkan bahwa komunikasi menunjukan korelasi dengan pelaksanaan organisasi secara keseluruhan. Pace \& Faules dalam Cangara (2006) menyatakan karyawan yang memiliki informasi yang lebih baik akan menjadi karyawan yang baik pula.

Komunikasi dalam organisasi dapat terjadi dalam bentuk kata-kata yang tertulis atau yang diucapkan, atau simbol-simbol yang yang menghasilkan perubahan tingkah laku dalam organisasi, baik antara manajer dengan karyawan yang terlibat dalam pemberian atau pertukaran informasi (Ali, 2007).

a. Operasional-Internal, yakni menstruktur komunikasi yang dijalankan dalam sebuah organisasi dalam rangka mencapai tujuan kerja.

b. Operasional-Eksternal, yakni struktur komunikasi dalam organisasi yang berkosentrasi pada pencapaian tujuan kerja yang dilakukan oleh orang dan kelompok diluar organisasi.

c. Personal, yakni semua perubahan informasi dan perasaan yang dirasakan oleh manusia yang berlangsung kapan saja.

Jaringan komunikasi sangat penting dalam pengembangan organisasi. Jaringan merupakan sebuah sistem dari garis komunikasi yang berhubungan dengan pengirim dan penerima di dalam sebuah fungsi 
sosial organisasi, yang mempengaruhi perilaku individu yang bekerja di dalamnya dan posisi individu yang bekerja dalam jaringan tersebut.

Pace \& Faules (2005) membagi empat fungsi jaringan komunikasi, yaitu:

a. Keteraturan jaringan adalah jaringan komunikasi yang teratur berhubungan dengan tujuan organisasi mengenai jaminan kesesuaian untuk perencanaan, jaminan produktivitas, termasuk kontrol-kontrol, pesan-pesan, bentuk perintah dan umpan balik sub ordinat dengan superior (yang lebih tinggi dalam tugas aktivitas. Contohnya pernyataan kebijakan dan aturan-aturan).

b. Inovatif jaringan adalah jaringan komunikasi inovatif yang berusaha keras untuk memastikan adaptasi organisasi terhadap pengaruh internal dan eksternal (teknologi, sosiologi, pendidikan, ekonomi, politik) dan dukungan terhadap kelanjutan produktivitas dan keefektifan, termasuk pemecahan masalah, adaptasi atau perubahan strategis dan proses implementasi ide baru.

c. Keutuhan integratif atau pemeliharaan jaringan adalah termasuk perasaan terhadap diri sendiri, gabungan (solidaritas) dan kerja yang secara langsung berhubungan dengan tujuan organisasi, terutama masalah moral karyawan.

d. Jaringan informatif Instruktif bertujuan untuk menjamin tujuan yang lebih cocok, sesuai, bermoral dan institusional. Dengan demikian akan meningkatkan produktivitas kinerja karyawan. 
Berdasarkan fungsionalnya arus komunikasi yang terjadi dalam organisasi formal terdiri dari arus vertikal (dari atas ke bawah dan dari bawah ke atas) dan arus horisontal (lateral atau silang).

a. Arus komunikasi vertikal dari atas ke bawah

Komunikasi merupakan saluran yang paling sering digunakan dalam organisasi. Arus komunikasi ini adalah pengiriman pesan dari pimpinan (supervisi) ke bawahan (subordinate). Arus ini digunakan untuk mengirim perintah, petunjuk, kebijakan, memorandum untuk pekerja pada tingkat yang lebih rendah dalam organisasi. Masalah yang paling mendasar komunikasi dari atas ke bawah hanya mempunyai satu arah saluran, yakni tidak menyediakan feedback (umpan balik) dari pekerja dalam organisasi itu. Asumsinya adalah jika pekerja mengetahui apa yang diketahui oleh manajer, maka mereka akan memaksakan diri untuk menyelesaikan masalah organisasi atau perusahaan (Endang, 2006).

b. Arus komunikasi vertikal dari bawah ke atas

Komunikasi ini adalah komunikasi yang berasal dari bawahan (subordinate) kepada atasan (supervisi) dalam rangka menyediakan feedback (umpan balik) kepada manajemen. Para pekerja menggunakan saluran komunikasi ini sebagai kesempatan untuk mengungkapkan ide-ide atau gagasan yang mereka ketahui. Asumsi dasar dari komunikasi ini adalah bahwa pekerja harus diperlakukan sebagai partner dalam mencari jalan terbaik untuk mencapai tujuan. Komunikasi dari bawah ke atas akan menarik ide ide dan membantu 
pekerja untuk menerima jawaban yang lebih baik tentang masalah dan tanggung jawabnya serta membantu kemudahan arus dan penerimaan komunikasi dari bawahan ke atasan (Mulyana, 2005).

3. Arus komunikasi horisontal

Komunikasi ini merupakan arus pengiriman dan penerimaan pesan yang terjadi antara pimpinan dan bawahan. Hasil dari beberapa studi mengungkapkan bahwa sekitar 2/3 dari organisasi yang ada menggunakan arus komunikasi ini. Komunikasi horisontal dikenal sebagai komunikasi lateral atau silang dan merupakan arus pemahaman yang paling kuat dalam komunikasi. Komunikasi ini berfokus pada koordinasi tugas, penyelesaian masalah, pembagian informasi, dan resolusi konflik. Banyak pesan akan mengalir pada semua lini tanpa melalui penyaringan. Komunikasi horisontal sangat penting bagi pekerja pada tingkat bawah untuk selalu berkomunikasi antara atasan dengan bawahan (Jamaluddin, 2006).

Komunikasi mempunyai empat fungsi dalam sebuah kelompok atau organisasi, yaitu fungsi kendali, motivasi, pernyataan emosi, dan informasi (Robbins, 2007). Komunikasi berfungsi untuk mengendalikan perilaku anggotanya dalam beberapa cara. Organisasi mempunyai otoritas hierarkis dan pedoman resmi di mana anggota-anggotanya diwajibkan untuk mematuhinya.

Komunikasi memelihara motivasi dengan memberikan penjelasan kepada para karyawan tentang apa yang harus dilakukan, seberapa baik mereka mengerjakannya, dan apa yang dapat dilakukan untuk 
meningkatkan kinerja jika sedang berada di bawah standar. Komunikasi yang terjadi dalam kelompok merupakan suatu mekanisme mendasar di mana para anggotanya dapat mengungkapkan dan melukiskan perasaan kecewa dan rasa puas mereka. Oleh karenanya, komunikasi adalah jalan untuk menyatakan emosi perasaan dan pemenuhan kebutuhan sosial.

Fungsi terakhir komunikasi berhubungan dengan perannya dalam memfasilitasi pengambilan keputusan. Fungsi tersebut memberikan informasi bagi perseorangan atau kelompok untuk membuat keputusan dengan menyertakan data untuk mengidentifikasi dan mengevaluasi pilihan. Dalam pelaksanaan tugas sebagai pimpinan tidak jarang menemui kesulitan bagaimana cara menyampaikan gagasan, pengarahan atau perintah sehingga dapat dimengerti, diterima dan dilaksanakan oleh bawahan. Ketidakberesan, ketidak mampuan atau ketidaklancaran pemimpin dalam berkomunikasi dengan bawahannya menjadi petunjuk bahwa kemampuan pemimpin dalam berkomunikasi kurang baik.

Menurut Hunsaker dan Alessandra (2005) bahwa penampilan diri memegang peranan penting dalam pergaulan dan hubungan kita dengan orang lain, baik secara positif maupun negatif. Penampilan diri yang baik mempercepat perkembangan keakraban dan saling percaya dengan orang lain. Sebaliknya, penampilan yang tidak baik akan menghambat suasana hubungan pribadi dan komunikasi. Selain masalah penampilan, kemampuan berkomunikasi pemimpin dipengaruhi oleh kemampuannya dalam hal: mendengarkan bawahan, bertanya kepada bawahan, nada suara dan gerak-gerik, serta memberi dan menerima umpan balik. 
Komunikasi merupakan pendukung utama agar kepemimpinan bisa efektif, karena seringkali kegagalan kepemimpinan diakibatkan karena lemahnya kemampuan berkomunikasi. Menurut Robbin (2007) bahwa kegagalan bekerja $70 \%$ diakibatkan oleh kegagalan komunikasi. Dengan demikian jelas bahwa kinerja pegawai dipengaruhi oleh kemampuan berkomunikasi seorang pimpinan, khususnya dalam membangun kerja tim sebagai satu kesatuan untuk mencapai tujuan.

Komunikasi menurut Rasidah (2004) adalah kemampuan individu untuk berkomunikasi secara efektif. Semakin tinggi kemampuan komunikasi yang dimiliki karyawan, maka semakin baik kinerja karyawan tersebut. Komunikasi yang efektif dibentuk oleh 3 aspek yaitu: (1) Motivasi komunikasi, yakni kesediaan untuk mendekati atau menghindari interaksi dengan yang lain, yang diukur dengan indikator empirik: (a) memiliki rasa percaya diri dalam memulai komunikasi, dan (b) kemampuan dalam membedakan sikap saat berkomunikasi dengan rekan kerja atau pelanggan; (2) Pengetahuan komunikasi, yakni memiliki pengetahuan prosedural untuk menyusun dan menjalankan skenario komunikasi dalam situasi sosial yang berbeda dan memiliki kemampuan perseptif untuk membaca situasi, yang akan diukur dengan indikator empirik: (a) mendapat pendidikan atau pelatihan mengenai komunikasi, (b) memiliki pengalaman kerja di bidang yang sama; dan (3) Keterampilan komunikasi, yakni kinerja aktual dari perilaku komunikator saat melakukan komunikasi, yang akan diukur dengan indikator empirik: (a) kemampuan menjalankan instruksi dengan baik, (b) kemampuan memberikan kritik dengan tepat 
saat berkomunikasi, (c) kesediaan menerima saran dengan baik saat berkomunikasi.

Berdasarkan uraian di atas, maka dapat disimpulkan bahwa komunikasi adalah jalinan pengertian antara pihak yang satu dengan pihak yang lain, sehingga apa yang dikomunikasikan dapat dimengerti, dipikirkan dan akhirnya dilaksanakan. Indikator yang digunakan adalah: memiliki rasa percaya diri dalam memulai komunikasi, mendapat pendidikan atau pelatihan mengenai komunikasi, berusaha menjalankan instruksi dengan baik, mampu memberikan saran dengan tepat saat berkomunikasi, dan bersedia menerima kritik saat berkomunikasi.

\section{E. Penelitian Terdahulu}

Penelitian terdahulu sangat penting dalam melakukan penelitian, karena dapat dijadikan acuan dan perbandingan secara komparatif mengenai obyek penelitian sesuai dengan variabel yang diamati. Berbagai penelitian yang telah dilakukan sebelumnya yaitu :

1. Menurut Ali (2007) dalam penelitiannya yang berjudul: "Hubungan Efektivitas Komunikasi Organisasi dengan Kinerja Guru pada SMK Nusantara Ciputat". Tujuan Penelitian ini adalah untuk mendukung ilmu pengetahuan manajemen sumber daya manusia khususnya yang terkait dengan hubungan efektivitas komunikasi efektif organisasi terhadap peningkatan kinerja guru. Penelitian ini juga menggunakan pendekatan kuantitatif dan kualitatif dengan responden berjumlah 60 orang dari kalangan guru. Penelitian ini menyatakan bahwa dalam 
suatu organisasi membutuhkan koordinasi antara satu dengan yang lain melalui komunikasi efektif, sehingga tercipta keharmonisan, saling pengertian dan kesepahaman yang mendukung terciptanya kinerja yang lebih baik menuju tercapainya tujuan organisasi.

2. Husein Anwar (2010) melakukan penelitian dengan judul: Pengaruh Komunikasi dan Koordinasi terhadap Kinerja Karyawan pada PT Bank Negara Indonesia (Persero) Tbk. Sentra Kredit Kecil Bandung. Metode analisis yang digunakan adalah analisis regresi linier berganda. Hasil penelitian menunjukkan komunikasi dan koordinasi berpengaruh signifikan terhadap kinerja karyawan. Jika perencanaan terlaksana dengan baik dan keterbukaan atasan dalam berkomunikasi dengan bawahannya meningkat, maka kinerja karyawan akan meningkat.

3. Sudirman (2011), dalam penelitiannya yang berjudul Pengaruh Perencanaan, Komunikasi, dan Disiplin terhadap Kinerja Pegawai pada Kantor Sekretariat Daerah Kabupaten Pinrang. Tujuan penelitian adalah mengetahui pengaruh variabel perencanaan, komunikasi, dan disiplin terhadap kinerja pegawai. Hasil penelitian menunjukkan bahwa variabel kompensasi, komunikasi, dan disiplin berpengaruh signifikan terhadap kinerja pegawai pada Badan Pemeriksa Keuangan Republik Indonesia (BPK-RI) di Makassar. Variabel komunikasi yang berpengaruh dominan terhadap kinerja pegawai.

4. Suryadi (2011) meneliti dengan judul "Pengaruh Komunikasi, Insentif, dan Disiplin terhadap Kinerja Pegawai pada kantor DPRD Kota Palopo. Penelitian ini bertujuan untuk mengetahui pengaruh 
komunikasi, insentif, dan disiplin terhadap kinerja pegawai pada kantor DPRD Kota Palopo. Data dianalisis dengan menggunakan analisis regresi linear berganda. Hasil penelitian menunjukkan bahwa secara simultan komunikasi, insentif, dan disiplin berpengaruh positif dan signifikan terhadap kinerja pegawai pada kantor DPRD Kota Palopo, dan insentif yang memberikan pengaruh dominan.

5. Rosliani Kadir (2011) meneliti dengan judul "Pengaruh Perencanaan, Kompetensi, dan Komitmen Organisasi terhadap Kinerja Pegawai pada Badan Kepegawaian dan Diklat Daerah Kabupaten Gowa. Penelitian ini bertujuan untuk mengetahui pengaruh perencanaan, kompetensi, dan komitmen organisasi terhadap kinerja pegawai pada Badan Kepegawaian dan Diklat Daerah Kabupaten Gowa. Data dianalisis dengan menggunakan analisis regresi linear berganda. Hasil penelitian menunjukkan bahwa perencanaan, kompetensi, dan komitmen organisasi berpengaruh signifikan dan positif terhadap kinerja pegawai Badan Kepegawaian dan Diklat Daerah Kabupaten Gowa.

Berdasarkan ketiga hasil penelitian di atas, maka dapat dijadikan sebagai acuan dan bahan referensi dalam menganalisis pengaruh perencanaan dan komunikasi terhadap kinerja karyawan PT Titipan Mas Area $\mathrm{V}$ Makassar. Sealain itu, dapat mengetahui ada tidaknya perbedaan dan persamaan dari penelitian terdahulu, dimana hasil penelitian ini dapat sama dan dapat berbeda, karena adanya persamaan dan perbedaan dari variabel yang diteliti. 


\section{BAB III}

\section{KERANGKA KONSEPTUAL DAN HIPOTESIS}

\section{A. Kerangka Konseptual}

Manajemen PT Titipan Mas Area V Makassar selalu berupaya untuk mempertahankan serta memberdayakan seluruh sumber daya yang dimiliki terutama karyawannya dalam upaya peningkatan kinerjanya. Kinerja karyawan merupakan hasil kerja karyawan, baik secara individu maupun secara kelompok sesuai bidang tugasnya. Rendahnya suatu kinerja diakibatkan gagalnya pelaksanaan suatu hasil kerja secara optimal. Sebagian besar kegagalan bekerja diakibatkan oleh kegagalan perencanaan dan komunikasi, terutama kurang efektifnya perencanaan dan komunikasi dalam perusahaan. Menurut Rivai (2005), kinerja pegawai merupakan perilaku nyata yang ditampilkan setiap orang sebagai prestasi kerja yang dihasilkan oleh pegawai sesuai dengan perannya dalam perusahaan. Kinerja pegawai merupakan suatu hal yang sangat penting dalam upaya perusahaan mencapai tujuannya.

Pada dasarnya kinerja karyawan merupakan hasil kerja secara kualitas dan kuantitas yang dicapai oleh seorang pegawai dalam melaksanakan tugasnya sesuai dengan tanggungjawab yang diberikan kepadanya (Anwar, 2000). Gibson et.al., (2005) menyatakan kinerja adalah catatan terhadap hasil produksi dan pekerjaan atau aktivitas tertentu dalam periode waktu tertentu. 
Kinerja karyawan adalah hasil kerja karyawan baik dari segi kualitas maupun kuantitas berdasarkan standar kerja yang telah ditentukan. Kinerja individu ini akan tercapai apabila didukung oleh atribut individu, upaya kerja (work effort) dan dukungan organisasi. Indikator pengukuran kinerja karyawan dalam penelitian ini mengacu pada teori yang dikemukakan oleh Bernadin dan Russel (2001: 243), meliputi: kualitas hasil kerja, kuantitas hasil kerja, efektivitas kerja, efisiensi kerja, dan kemandirian dalam bekerja.

Kinerja karyawan pada PT Titipan Mas Area V Makassar sangat ditentukan oleh perencanaan dan komunikasi yang diterapkan perusahaan. Oleh karena itu, kinerja karyawan dalam penelitian ini dianalisis dalam hubungannya dengan perencanaan dan komunikasi. Suatu hal yang sangat penting dalam melakukan kegiatan manajerial adalah perencanaan dan komunikasi, karena seorang manajer harus mampu menyusun perencanaan dalam mencapai tujuan organisasi yang memerlukan pertukaran ide, fakta dan pengalaman dengan orang lain.

Konsep perencanaan menurut Erly Suandy (2001:2) adalah proses penentuan tujuan organisasi (perusahaan) dan kemudian menyajikan (mengartikulasikan) dengan jelas strategi-strategi (program), taktik-taktik (tata cara pelaksanaan program) dan operasi (tindakan) yang diperlukan untuk mencapai tujuan perusahaan secara menyeluruh. Indikator yang digunakan dalam mengukur variabel perencanaan antara lain: penetapan tujuan organisasi yang jelas, mendefinisikan situasi sekarang untuk mencapai keberhasilan, mengenal dukungan dan kendala untuk 
mengatasi persoalan kerja, mengembangkan premis perencanaan dengan membuat peramalan rencana, dan mengembangkan metode pengawasan operasi rencana yang efektif. Kelima indikator diyakini mampu membentuk variabel perencanaan dalam mendukung peningkatan kinerja karyawan pada PT Titipan Mas Area V Makassar.

Menurut Stoner dalam Tunggal (2003), komunikasi adalah suatu proses agar fungsi-fungsi manajemen (merencanakan, mengorganisasi, memimpin, dan mengendalikan) yang dapat dilaksanakan. Komunikasi penting di dalam organisasi, karena komunikasi berlaku sebagai mata rantai koordinasi antara para pegawai dengan fungsi-fungsi organisasi. Perusahaan yang progresif telah menyadari bahwa komunikasi organisasi adalah vital bagi operasi perusahaannya untuk berhasil dan menjadi suatu bagian integral dari proses manajemen. Komunikasi yang efektif dapat meningkatkan kinerja pegawai, karena dengan komunikasi yang efektif para pegawai dapat menjalin hubungan kerja yang harmonis dengan sesamanya maupun dengan atasan dan bawahannya. Oleh karena itu, indikator yang digunakan adalah: memiliki rasa percaya diri dalam memulai komunikasi, mendapat pendidikan atau pelatihan mengenai komunikasi, berusaha menjalankan instruksi dengan baik, mampu memberikan saran dengan tepat saat berkomunikasi, dan bersedia menerima kritik saat berkomunikasi. Kelima indikator tersebut diyakini mampu membentuk variabel komunikasi sehingga mampu mendukung peningkatan kinerja karyawan pada PT Titipan Mas Area V Makassar. 
Dari kedua variabel tersebut, merupakan faktor-faktor yang diyakini mempengaruhi kinerja karyawan pada PT Titipan Mas Area V Makassar. Jika hal tersebut dikelola dengan baik maka diharapkan kinerja karyawan tersebut akan meningkat secara signifikan. Berdasarkan uraian tersebut, maka dapat dinyatakan dalam skema konseptual sebagai berikut :

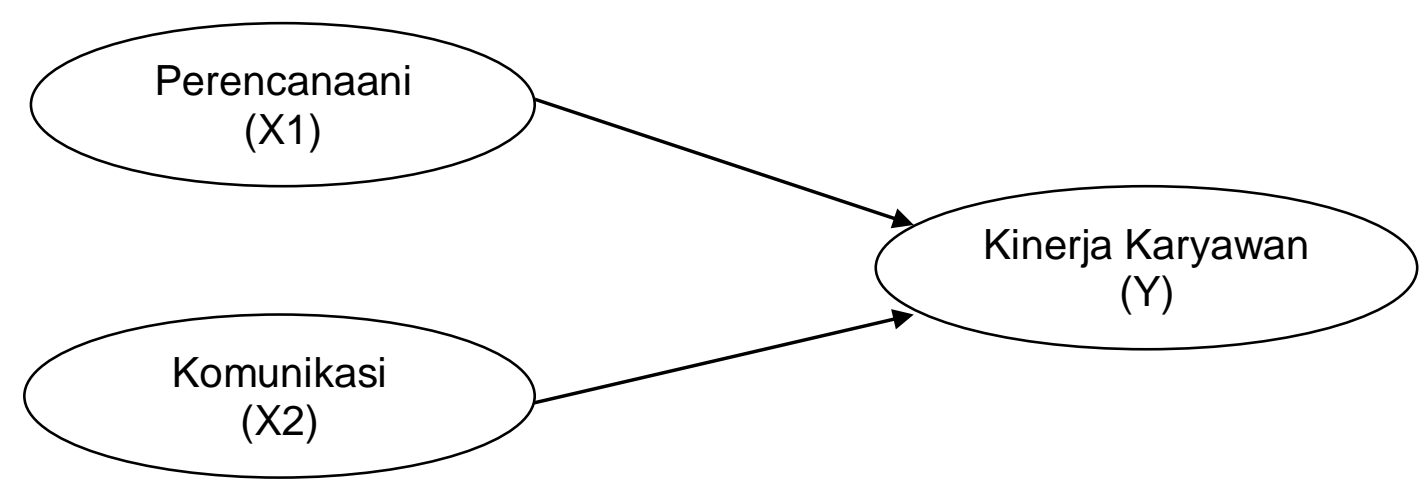

Gambar 2. Kerangka Konseptual Penelitian

\section{B. Hipotesis Penelitian}

Berdasarkan uraian kerangka konseptual di atas, maka hipotesis yang penulis ajukan adalah sebagai berikut :

1. Perencanaan dan komunikasi berpengaruh signifikan terhadap kinerja karyawan pada PT Titipan Mas Area V Makassar.

2. Variabel komunikasi yang paling besar pengaruhnya terhadap kinerja karyawan pada PT Titipan Mas Area V Makassar. 


\section{BAB IV \\ METODE PENELITIAN}

\section{A. Pendekatan Penelitian}

Penelitian tersebut dilakukan dengan menggunakan pendekatan deskriptif kuantitatif yaitu untuk memperoleh gambaran lengkap tentang variabel yang diteliti. Dalam hal ini variabel perencanaan, komunikasi, dan kinerja karyawan pada PT Titipan Mas Area V Makassar. Jenis penelitian ini bersifat survey yaitu menganalisis fakta dan data yang diperlukan untuk mendukung pembahasan penelitian, dalam memecahkan dan menjawab permasalahan yang diajukan.

\section{B. Lokasi dan Waktu Penelitian}

Lokasi penelitian dilaksanakan di Provinsi Sulawesi Selatan tepatnya pada PT Titipan Mas Area V Makassar yang terdiri atas 5 (lima) cabang, yaitu: Cabang Panakkukang di Jalan Boulevard Nomor 31 Panakkukang Makassar, Cabang Daya di Pasar Baru Daya, Cabang Butung di Pasar Grosir Butung, Cabang Gowa di Jl. KH. Wahid Hasyim, dan Cabang Parepare di Jalan Lasinrang. Pemilihan lokasi dilakukan dengan pertimbangan bahwa perusahaan ini bergerak di bidang jasa yang berupaya untuk meningkatkan kinerja karyawannya melalui kebijakan perencanaan, dan komunikasi. Sedangkan waktu dibutuhkan untuk melakukan penelitian ini adalah lebih kurang 3 bulan yaitu mulai bulan Desember 2014 sampai Februari 2015. 


\section{Jenis dan Sumber Data}

Jenis data yang digunakan dalam penelitian ini adalah:

1. Data kuantitatif, yaitu data yang diperoleh dan disajikan dalam bentuk angka-angka atau laporan.

2. Data kualitatif, yaitu data yang berupa informasi atau keterangan keterangan yang diperoleh dan disajikan dalam bentuk non angka.

Data yang diperlukan dalam penelitian ini bersumber dari:

1. Data primer adalah data yang diperoleh melalui hasil penelitian langsung terhadap obyek yang diteliti. Data tersebut diperoleh melalui metode observasi dari responden. Pihak yang dimaksud adalah Area Manager dari PT. Titipan Mas Area V Makassar beserta para staf HRD, Kantor Cabang dan Kantor Cabang Pembantu dalam memperoleh berbagai informasi yang dapat menunjang kelengkapan data.

3. Data sekunder adalah data yang diperoleh dari berbagai sumber antara lain melalui dokumentasi, atau laporan tertulis lainnya.

\section{Teknik Pengumpulan Data}

Metode pengumpulan data yang digunakan dalam penelitian ini adalah :

1. Observasi, yaitu melakukan pengumpulan data melalui pengamatan langsung yang berhubungan dengan perencanaan, komunikasi, dan kinerja karyawan dengan pendekatan pada bagian sumber daya manusia dan administrasi untuk mempeoleh data yang berkaitan dengan penelitian ini. 
2. Kuesioner, yaitu pengumpulan data yang dilakukan dengan cara mengedarkan daftar pertanyaan kepada responden yang disusun sesuai data yang dibutuhkan berdasarkan wawancara dan observasi pendahuluan.

3. Studi dokumentasi, yaitu penulis mencatat arsip-arsip atau dokumen dari PT Titipan Mas Area V Makassar.

\section{E. Populasi dan Sampel}

\section{Populasi}

Populasi dalam penelitian ini adalah karyawan pada PT Titipan Mas Area V Makassar sebanyak 200 karyawan.

\section{Sampel}

Dalam penelitian ini menggunakan metode sensus, yaitu pengambilan jumlah responden diambil dari seluruh anggota populasi (Suparmoko, 1999), jumlah 200 karyawan pada PT Titipan Mas Area V Makassar. Namun untuk mengantisipasi pengembalian kuesioner, maka digunakan batas minimum sampel dalam data yang dianalisis. Sampel yang diambil untuk penelitian ini adalah karyawan PT. Titipan Mas Area $\mathrm{V}$ Makassar dengan menggunakan metode penentuan besarnya sampel dengan menggunakan metode Slovin dengan rumus sebagai berikut (Umar, 2003: 108) :

$$
n=\frac{N}{1+N \cdot e^{2}}
$$




\section{Keterangan :}

$\mathrm{n}$ : Ukuran sampel

$\mathrm{N}$ : Ukuran populasi

e : Presentase kelonggaran ketidaktelitian karena kesalahan pengambilan sampel yang masih dapat ditoleransi atau yang diinginkan.

Dengan menggunakan persentase kelonggaran (5\%) maka dari populasi sebanyak 200 orang diperoleh ukuran sampel sebesar:

$$
\mathrm{n}=\frac{200}{1+\left(200 \times(0.05)^{2}\right)}=113 \text { responden }
$$

Untuk menghitung jumlah sampel yang diambil dari masingmasing sub populasi digunakan teknik stratified random sampling, yaitu ukuran sampel dikalikan dengan populasi masing-masing subpopulasi sebagai berikut :

Tabel 1. Proporsi Sampel Penelitian

\begin{tabular}{|c|c|c|c|c|}
\hline NO & $\begin{array}{c}\text { Unit Kerja } \\
\text { Karyawan } \\
(\mathbf{1})\end{array}$ & $\begin{array}{c}\text { Populasi } \\
\text { Nersentase }\end{array}$ & $\begin{array}{c}\text { Sampel } \\
=(2): 200 \times \text { jumlah } \\
(4)\end{array}$ \\
\hline 1 & Kantor Cabang Pana kkukang & 75 & 37.5 & $\frac{75}{200} \times 113=42,38=42$ \\
\hline 2 & Kantor Cabang Daya & 20 & 10 & $\frac{20}{200} \times 113=11,3=11$ \\
\hline 3 & Kantor Cabang Butung & 40 & 20 & $\frac{40}{200} \times 113=22,6=23$ \\
\hline 4 & Kantor Cabang Gowa & 35 & 17.5 & $\frac{35}{200} \times 113=19,78=20$ \\
\hline 5 & Kantor Cabang Parepare & 30 & 15 & $\frac{30}{200} \times 113=16,95=17$ \\
\hline \multicolumn{2}{|c|}{ Jumlah } & 200 & 100 & 113 \\
\hline
\end{tabular}

Sumber: HRD PT Titipan Mas Area V Makassar, 2014

Jadi sampel yang diambil dalam penelitian sebanyak 113 sampel. 


\section{F. Metode Analisa Data}

Teknik analisis data yang digunakan dalam penelitian ini adalah sebagai berikut:

1. Analisis deskriptif, yaitu memberikan gambaran secara utuh tentang kegiatan pada PT Titipan Mas Area V Makassar yang berkaitan dengan perencanaan, komunikasi, dan kinerja karyawan sesuai temuan di lapangan.

2. Analisis kuantitatif dengan menggunakan metode analisis regresi linier berganda untuk menganalisis pengaruh perencanaan, dan komunikasi terhadap kinerja karyawan pada PT Titipan Mas Area V Makassar, dengan menggunakan rumus (Sugiyono, 2004: 212) sebagai berikut:

$$
\begin{aligned}
Y=b_{0}+b_{1} X_{1}+b_{2} X_{2} & +b_{3} X_{3}+e \\
\text { Dimana: } & =\text { Kinerja karyawan } \\
b_{0} & =\text { Intercept/konstanta } \\
X_{1} & =\text { Perencanaan } \\
X_{2} & =\text { Komunikasi } \\
b_{1}-b_{2} & =\text { Koefisien Regresi } \\
e & =\text { Distrubance Error }
\end{aligned}
$$

3. Pengujian Hipotesis yang digunakan adalah:

a. Uji $R$ dan $R^{2}$

Koefisien korelasi $\mathrm{R}$ menunjukkan besar kecilnya keeratan hubungan (korelasi) antara variabel bebas secara bersama-sama dengan variabel terikat. Sedangkan nilai $R^{2}$ menunjukkan koefisien determinasi yaitu mengukur besar persentase perubahan variabel 
terikat yang diakibatkan oleh perubahan variabel bebas secara bersama-sama.

b. Uji-F (uji serempak)

Uji ini digunakan untuk mengetahui derajat atau kekuatan pengaruh antara variabel bebas $\left(X_{1}, X_{2}\right.$, dan $\left.X_{3}\right)$ secara serempak atau bersama-sama dengan variabel terikat $(\mathrm{Y})$. Koefisien ini didapat dengan mengambil akar dari Koefisien Determinasi R.

c. Uji-t (parsial)

Uji ini digunakan untuk mengetahui derajat atau kekuatan pengaruh antara variabel bebas $\left(X_{1}, X_{2}\right.$, dan $\left.X_{3}\right)$ secara parsial (sendiri-sendiri) dengan variabel terikat $(\mathrm{Y})$. Pengujian ini dilakukan dengan membandingkan t-hitung dengan t-tabel pada taraf signifikan $5 \%$. Adapun persyaratan uji-t adalah sebagai berikut:

1) Jika t-hitung > t-tabel, maka Ho ditolak dan Ha diterima, artinya variabel bebas dapat menerangkan variabel terikat dan ada pengaruh diantara kedua variabel yang akan diuji.

2) Jika t-hitung < t-tabel, maka Ho diterima dan Ha ditolak, artinya variabel bebas tidak dapat menerangkan variabel terikat dan tidak ada pengaruh diantara kedua variabel yang akan diuji.

d. Uji Validitas dan Reliabilitas

1) Uji Validitas

Uji validitas data digunakan sebagai alat untuk mengukur sah atau valid tidaknya suatu kuisioner. Suatu kuesioner dapat dikatakan valid atau sah, jika pertanyaan pada kuesioner 
mampu untuk mengungkapkan sesuatu yang akan diukur oleh kuesioner tersebut dengan menggunakan korelasi bivariate. Menurut Sugiyono (2004:271), apabila validitas setiap pertanyaan lebih besar dari 0,60 maka butir pertanyaan dianggap valid.

Pengujian validitas dilakukan dengan beberapa langkahlangkah, yaitu: a) Mendefinisikan secara operasional konsep yang akan diukur; b) Melakukan uji coba skala pengukuran dengan menggunakan responden; c) Mempersiapkan tabel jawaban; dan d) Menghitung korelasi bivariate dengan menggunakan program SPSS.

2) Uji Reliabilitas

Reliabilitas adalah suatu indeks tentang sejauhmana suatu alat ukur dapat dipercaya atau diandalkan. Jika suatu alat ukur dapat digunakan dua kali untuk mengukur gejala yang sama dan hasil pengukurannya diproses relatif secara konsisten, maka alat ukur tersebut dianggap reliable. Artinya suatu alat ukur yang digunakan konsisten dalam mengukur gejala yang sama. Menurut Sugiyono (2004:273) bahwa uji reliabilitas ditentukan dengan koefisien Cronbach's Alpha dengan mensyaratkan suatu instrument yang reliable jika memiliki koefisien Cronbach's Alpha di atas 0,60. 
e. Uji Normalitas

Dalam melakukan uji regresi disyaratkan agar data yang digunakan normal. Pada penelitian ini untuk mengetahui normalitas distribusi data dilakukan dengan melihat nilai residual pada model regresi yang akan diuji. Jika residual berdistribusi normal maka nilai-nilai sebaran data akan terletak di sekitar garis lurus (Sugiyono, 2004).

Normal-tidaknya distribusi data suatu peubah ditunjukkan oleh besarnya nilai Asymptotic significant dari aplikasi alat uji Onesample Kolmogorov-Smirnov. Apabila Asymptotic significant data lebih besar daripada 5\%, maka data tersebut tergolong memiliki pola distribusi normal. Sebaliknya, apabila Asymptotic significant kecil daripada atau sama dengan 5\%, maka data dimaksud memiliki pola distribusi yang tidak normal (Hair, et.al, 1998).

f. Uji Multikolinearitas

Uji multikolinearitas bertujuan untuk menguji apakah model regresi ditemukan adanya korelasi bebas (independen). Deteksi terhadap ada tidaknya multikolinearitas yaitu dengan menganalisis matriks korelasi variabel bebas. Keberadaan multikolinearitas dapat dilihat melalui nilai VIF (Variance Inflation Factors) atau nilai toleransinya. Keberadaan multikolinearitas dapat diketahui apabila nilai VIF > 10 atau secara kebalikannya dengan melihat nilai toleransinya $<0,1$ dan sebaliknya. Bila nilai VIF dari masing-masing variabel $<10$, dan nilai toleransinya $>0,1$, maka dapat dikatakan 
tidak terdapat gejala multikolinieritas atau hubungan yang terjadi antar variabel bebas dapat ditoleransi sehingga tidak akan mengganggu hasil regresi.

g. Uji Heterokedastisitas

Uji heterokedastisitas dilakukan untuk menguji apakah dalam model regresi terjadi ketidaksamaan varians dari residual satu pengamatan ke pengamatan lain. Dalam regresi, salah satu asumsi yang harus dipenuhi adalah bahwa varians dari residual satu pengamatan ke pengamatan lain tidak memiliki pola tertentu. Pola yang tidak sama ini ditunjukkan dengan nilai yang tidak sama antar satu varians dari residual yang disebut heterokedastisitas, sedangkan adanya gejala varians residual yang sama dari satu pengamatan ke pengamatan lain disebut homokedastisitas.

Heterokedastisitas akan muncul apabila terdapat pola tertentu antar keduanya seperti pola bergelombang dan kontinyu atau menyempit atau melebar teratur. Homokedastisitas akan muncul apabila tidak diperoleh pola yang jelas atau titik-titik yang diperoleh menyebar di atas dan di bawah angka 0 pada sumbu $\mathrm{Y}$, sehingga tidak menghasilkan parameter bias yang menyebabkan kesalahan dalam perlakuannya.

\section{G. Definisi Operasional dan Pengukuran Variabel}

Untuk menyamakan persepsi dalam penelitian ini, maka ditetapkan definisi operasional dengan beberapa istilah sebagai berikut: 
1. Kinerja karyawan $(\mathrm{Y})$ adalah hasil kerja yang dicapai karyawan dalam melakukan suatu pekerjaan berdasarkan tugas pokok dan fungsinya. Indikator kinerja karyawan dalam penelitian ini adalah: (a) kualitas hasil kerja, (b) kuantitas hasil kerja, (c) efektivitas kerja, (d) efisiensi kerja, dan (e) kemandirian bekerja. Penilaian indikator menggunakan skala Likert yang terdiri atas lima kategori, yaitu: sangat setuju (5), setuju (4), cukup setuju (3), tidak setuju (2), sangat tidak setuju (1).

2. Perencanaan $\left(X_{1}\right)$ adalah penentuan tujuan organisasi (perusahaan) dan kemudian menyajikan (mengartikulasikan) dengan jelas strategistrategi (program), taktik-taktik (tata cara pelaksanaan program) dan operasi (tindakan) diperlukan untuk mencapai tujuan perusahaan secara menyeluruh. Indikator kinerja karyawan dalam penelitian ini adalah: (a) penetapan tujuan organisasi yang jelas, (b) mendefinisikan situasi sekarang untuk mencapai keberhasilan, (c) mengenal dukungan dan kendala untuk mengatasi persoalan kerja, (d) mengembangkan premis perencanaan dengan membuat peramalan rencana, (e) mengembangkan metode pengawasan operasi rencana yang efektif. Penilaian indikator menggunakan skala Likert yang terdiri atas lima kategori, yaitu: sangat setuju (5), setuju (4), cukup setuju (3), tidak setuju (2), dan sangat tidak setuju (1).

3. Komunikasi $\left(X_{2}\right)$ adalah jalinan pengertian antara pihak yang satu dengan pihak yang lain, sehingga apa yang dikomunikasikan dapat dimengerti, dipikirkan dan akhirnya dilaksanakan. Indikator komunikasi dalam penelitian ini adalah: (a) Memiliki rasa percaya diri dalam 
memulai komunikasi, (b) Mendapat pendidikan/pelatihan mengenai komunikasi, (c) Berusaha menjalankan instruksi dengan baik, (d) Mampu memberikan saran dengan tepat saat berkomunikasi, dan (e) Bersedia menerima kritik dengan baik saat berkomunikasi. Penilaian indikator menggunakan skala Likert yang terdiri atas lima kategori, yaitu: sangat setuju (5), setuju (4), cukup setuju (3), tidak setuju (2), dan sangat tidak setuju (1). 


\section{BAB V}

\section{HASIL PENELITIAN DAN PEMBAHASAN}

\section{A. Karakteristik Responden}

Penelitian ini dilakukan terhadap seluruh sampel karyawan pada PT Titipan Mas Area V Makassar yang berjumlah 113 orang yang diperoleh melalui kuesioner, dan data yang terjaring dan dianalisis juga berjumlah 113 orang, berarti kuesioner yang diedarkan seluruhnya dikembalikan. Berikut ini akan dideskripsikan identitas responden yang meliputi: jenis kelamin, tingkat umur, tingkat pendidikan, dan masa kerja. Pengungkapan identitas responden tersebut semata dimaksudkan untuk menggambarkan berbagai karakteristik responden yang sempat terjaring dalam penelitian ini.

\section{Jenis Kelamin}

Jenis kelamin atau gender adalah suatu konsep kultural yang berupaya membuat pembedaan (distinction) dalam hal peran, perilaku, mentalitas, dan karakteristik emosional antara laki-laki dan perempuan yang berkembang dalam masyarakat (Jacobson, 2000:35). Jadi, jenis kelamin diartikan sebagai perbedaan yang tampak antara laki-laki dan perempuan dilihat dari segi nilai dan tingkah laku.

Adapun karakteristik responden menurut jenis kelamin pada PT Titipan Mas Area V Makassar, dapat dilihat pada Tabel 2. 
Tabel 2. Karakteristik Responden menurut Jenis Kelamin

\begin{tabular}{|c|c|c|}
\hline Jenis Kelamin & $\begin{array}{c}\text { Jumlah } \\
\text { (orang) }\end{array}$ & $\begin{array}{c}\text { Persentase } \\
(\%)\end{array}$ \\
\hline Laki-laki & 55 & 48,7 \\
Perempuan & 58 & 51,3 \\
\hline Jumlah & 113 & 100 \\
\hline
\end{tabular}

Sumber: Data Primer Setelah Diolah, 2015 (Lampiran 3)

Berdasarkan data pada Tabel 2 dapat dijelaskan karakteristik responden pada PT Titipan Mas Area V Makassar menurut jenis kelamin yang memiliki jumlah paling banyak adalah perempuan sebanyak 58 orang $(51,3 \%)$, sedangkan laki-laki lebih sedikit yakni 55 orang $(48,7 \%)$.

\section{Tingkat Umur}

Usia sangat menentukan tingkat kinerja karyawan pada sebuah organisasi. Dengan tingkat usia yang masih produktif tersebut akan berpengaruh terhadap penyelesaian tugas dan tanggung jawab karyawan yang tentunya memberikan dampak terhadap kinerja organisasi. Tingkat umur responden yang terkecil adalah 28 tahun dan terbesar adalah 48 tahun.

Adapun karakteristik responden menurut tingkat umur pada PT Titipan Mas Area V Makassar, dapat dilihat pada Tabel 3. 
Tabel 3. Karakteristik Responden menurut Tingkat Umur

\begin{tabular}{|c|c|c|}
\hline $\begin{array}{c}\text { Tingkat Umur } \\
\text { (tahun) }\end{array}$ & $\begin{array}{c}\text { Jumlah } \\
\text { (orang) }\end{array}$ & $\begin{array}{c}\text { Persentase } \\
\text { (\%) }\end{array}$ \\
\hline$\leq 32$ & 27 & 23,89 \\
$33-37$ & 51 & 45,13 \\
$38-42$ & 20 & 17,70 \\
$\geq 43$ & 15 & 13,27 \\
\hline Jumlah & 113 & 100,00 \\
\hline
\end{tabular}

Sumber: Data Primer Setelah Diolah, 2015 (Lampiran 3)

Tabel 3 menunjukkan karakteristik responden berdasarkan umur diperoleh data yang variatif. Data yang terjaring menunjukkan bahwa tingkat umur yang menempati proporsi terbesar adalah tingkat umur 35 - 41 tahun sebanyak 21 orang (40,39\%), kemudian diikuti tingkat umur 42 - 48 tahun sebanyak 17 orang (32,69\%). Sedangkan tingkat umur dengan proporsi terkecil adalah 28 - 34 tahun dan $49-55$ tahun dengan masing-masing sebanyak 7 orang $(13,46 \%)$. Hal ini berarti responden umumnya memiliki tingkat umur produktif yang diharapkan dapat menyelesaikan tugas yang menjadi tanggung jawabnya dengan baik.

\section{Tingkat Pendidikan}

Tingkat pendidkan adalah jenjang pendidikan yang telah ditamati oleh responden sesuai dengan latar belakang pendidikan dan disiplin ilmu yang ditekuninya dan diakui oleh pemerintah. Tingkat pendidikan 
formal tersebut akan membentuk cara berpikir dan bertindak pegawai terutama dalam melaksanakan tanggungjawabnya.

Adapun karakteristik responden menurut tingkat pendidikan di PT Titipan Mas Area V Makassar, dapat dilihat pada Tabel 4.

Tabel 4. Karakteristik Responden menurut Tingkat Pendidikan

\begin{tabular}{|c|c|c|}
\hline $\begin{array}{c}\text { Tingkat Umur } \\
\text { (tahun) }\end{array}$ & $\begin{array}{c}\text { Jumlah } \\
\text { (orang) }\end{array}$ & $\begin{array}{c}\text { Persentase } \\
(\%)\end{array}$ \\
\hline SLTA & 34 & 30,1 \\
Diploma & 24 & 21,2 \\
S1 & 50 & 44,2 \\
S2 & 5 & 4,4 \\
\hline Jumlah & 113 & 100 \\
\hline
\end{tabular}

Sumber: Data Primer Setelah Diolah, 2015 (Lampiran 3)

Data pada Tabel 4 menunjukkan bahwa karakteristik responden berdasarkan tingkat pendidikan diperoleh data yang variatif. Data yang terjaring menunjukkan bahwa tingkat pendidikan yang menempati proporsi tertinggi adalah SLTA sebanyak 34 orang $(30,1 \%)$, kemudian diikuti oleh tingkat pendidikan Diploma sebanyak 24 orang $(21,2 \%)$, tingkat pendidikan S1 sebanyak 50 orang $(44,2 \%)$ dan tingkat pendidikan S2 sebanyak 5 orang $(4,4 \%)$. Hal ini berarti tingkat pendidikan responden tergolong cukup memadai sehingga diharapkan dapat menyelesaikan tugas dengan baik. 


\section{B. Pengujian Instrumen Penelitian}

\section{Uji Validitas}

Uji validitas dilakukan dengan mengkorelasikan skor tiap item dengan skor total dari masing-masing atribut. Uji validitas digunakan untuk melihat ketepatan dan kecermatan dari sebuah instrumen penelitian dalam fungsi ukurnya mengukur item-item pernyataan yang dibuat. Instrumen yang valid mempunyai arti bahwa alat ukur yang digunakan dalam bentuk pernyataan untuk memperoleh data (mengukur) juga dinyatakan valid. Item pernyataan yang memiliki korelasi positif tinggi dapat dianggap memiliki validitas yang tinggi pula.

Menurut Sugiyono (2007:233), corrected item total corelation merupakan korelasi antar skor total item (butir penyataan), sehingga interpretasinya dengan mengkonsultasikan nilai kritis $r$-tabel, jika $r$ hitung $>$ nilai kritis $r$-tabel product moment maka instrument dinyatakan valid atau dapat dikatakan bahwa butir pernyataan dari cerminan setiap variabel dalam penelitian ini keberadaannya pada instrumen penelitian dinyatakan valid (sahih). Adapun hasil uji validitas dari setiap butir pernyataan variabel dalam penelitian ini, dapat dilihat pada Tabel 5. 
Tabel 5. Hasil Uji Validitas Instrumen Penelitian

\begin{tabular}{|l|c|c|c|}
\hline Instrumen Penelitian & $\begin{array}{c}\text { Corrected } \\
\text { Item-Total } \\
\text { Correlation }\end{array}$ & $\begin{array}{c}\mathrm{r} \text {-Product Moment } \\
(\mathrm{r} \text {-tabel }) \\
(\mathrm{n}=113 ; \boldsymbol{\alpha} 0,05)\end{array}$ & Keterangan \\
\hline Kinerja karyawan 1 & 0,797 & 0,195 & Valid \\
Kinerja karyawan 2 & 0,774 & 0,195 & Valid \\
Kinerja karyawan 3 & 0,889 & 0,195 & Valid \\
Kinerja karyawan 4 & 0,835 & 0,195 & Valid \\
Kinerja karyawan 5 & 0,909 & 0,195 & Valid \\
Perencanaan 1 & 0,801 & 0,195 & Valid \\
Perencanaan 2 & 0,844 & 0,195 & Valid \\
Perencanaan 3 & 0,836 & 0,195 & Valid \\
Perencanaan 4 & 0,831 & 0,195 & Valid \\
Perencanaan 5 & 0,840 & 0,195 & Valid \\
Komunikasi 1 & 0,846 & 0,195 & Valid \\
Komunikasi 2 & 0,828 & 0,195 & Valid \\
Komunikasi 3 & 0,840 & 0,195 & Valid \\
Komunikasi 4 & 0,847 & 0,195 & Valid \\
Komunikasi 5 & 0,823 & 0,195 & Valid \\
\hline
\end{tabular}

Sumber: Hasil Analisis, 2015 (Lampiran 5)

Berdasarkan hasil uji validitas (kekonsistenan) yang terlihat pada Tabel 5, maka diperoleh nilai $r$ hitung dari 15 butir pernyataan berada antara 0,774 sampai 0,909 , dimana nilai $r$ hitung $>$ nilai $r$ tabel, untuk $\mathrm{n}=113$ pada taraf $\alpha 0,05$ diperoleh $\mathrm{r}$ tabel $=0,195$. Dengan demikian, maka dapat dinyatakan bahwa semua butir pernyataan pada kuisioner adalah valid atau mampu mengungkapkan sesuatu yang akan diukur oleh kuesioner, sehingga dapat digunakan untuk analisis selanjutnya. 
Hasil uji validitas instrumen dari variabel kinerja karyawan diperoleh nilai Corrected Item Total Correlation (r-hitung) antara $0,774-0,909$ atau $r$ hitung $>r$ tabel 0,195 . Hal ini berarti setiap butir pernyataan dari variabel kinerja karyawan yang digunakan dalam penelitian ini adalah valid (sahih).

Hasil uji validitas instrumen dari variabel perencanaan diperoleh nilai Corrected Item Total Correlation ( $r$ hitung) antara 0,801 - 0,844 atau $r$ hitung $>r$ tabel 0,195 . Hal ini berarti setiap butir pernyataan dari variabel perencanaan yang digunakan dalam penelitian ini adalah konsisten (valid).

Hasil uji validitas instrumen dari variabel komunikasi diperoleh nilai Corrected Item Total Correlation ( $r$ hitung) antara 0,823 - 0,847 atau $r$ hitung $>r$ tabel 0,279 . Hal ini berarti setiap butir pernyataan dari variabel komunikasi yang digunakan dalam penelitian ini adalah konsisten (valid).

\section{Uji Reliabilitas}

Instrumen dalam penelitian ini dikatakan reliabel atau handal apabila dipergunakan beberapa kali untuk mengukur obyek yang sama sehingga menghasilkan data yang sama pula. Untuk melakukan uji reliabilitas terhadap instrumen penelitian adalah dengan menggunakan alpha cronbach yang mengelompokkan item-item menjadi dua atau beberapa belahan. Jika $r$ hitung $>$ nilai kritis $r$-tabel Product Moment maka data penelitian dianggap realiabel atau handal untuk digunakan 
sebagai input dalam proses penganalisisan data guna menguji hipotesis penelitian.

Adapun hasil uji reliabilitas dari setiap butir pernyataan variabel yang digunakan dalam penelitian ini, dapat dilihat pada Tabel 6.

Tabel 6. Hasil Uji Reliabilitas Instrumen Penelitian

\begin{tabular}{|c|c|c|c|}
\hline Instrumen Penelitian & $\begin{array}{l}\text { Cronbach's } \\
\text { Alpha if Item } \\
\text { Deleted }\end{array}$ & $\begin{array}{c}r \text { Product Moment } \\
(r-\text { tabel }) \\
(n=113 ; a 0,05)\end{array}$ & Keterangan \\
\hline Kinerja karyawan 1 & 0,972 & 0,195 & handal \\
\hline Kinerja karyawan 2 & 0,972 & 0,195 & handal \\
\hline Kinerja karyawan 3 & 0,970 & 0,195 & handal \\
\hline Kinerja karyawan 4 & 0,971 & 0,195 & handal \\
\hline Kinerja karyawan 5 & 0,970 & 0,195 & handal \\
\hline Perencanaan 1 & 0,972 & 0,195 & handal \\
\hline Perencanaan 2 & 0,971 & 0,195 & handal \\
\hline Perencanaan 3 & 0,971 & 0,195 & handal \\
\hline Perencanaan 4 & 0,971 & 0,195 & handal \\
\hline Perencanaan 5 & 0,971 & 0,195 & handal \\
\hline Komunikasi 1 & 0,971 & 0,195 & handal \\
\hline Komunikasi 2 & 0,971 & 0,195 & handal \\
\hline Komunikasi 3 & 0,972 & 0,195 & handal \\
\hline Komunikasi 4 & 0,971 & 0,195 & handal \\
\hline Komunikasi 5 & 0,972 & 0,195 & handal \\
\hline
\end{tabular}

Sumber: Hasil Analisis, 2015 (Lampiran 5)

Hasil analisis uji reliabilitas (kehandalan) tersebut di atas diperoleh nilai Cronbach's alpha (r-hitung) dari 15 item pernyataan berada antara 0,970 sampai 0,972, dimana nilai $r$ hitung $>$ nilai $r$ tabel 
0,195. Hal ini berarti setiap butir pernyataan dari variabel yang digunakan dalam penelitian ini adalah handal atau dapat dikatakan bahwa instrumen penelitian yang digunakan dalam fungsi ukurnya tidak menimbulkan arti ganda sehingga memiliki kehandalan dalam mengukur pengaruh perencanaan dan komunikasi terhadap kinerja karyawan pada PT Titipan Mas Area V Makassar.

Hasil uji reliabilitas instrumen dari variabel kinerja karyawan diperoleh nilai Cronbach Alpha ( $r$ hitung) antara 0,970 - 0,972 atau $r$ hitung $>r$ tabel 0,195 , yang berarti setiap butir pernyataan dari variabel kinerja karyawan yang digunakan dalam penelitian ini adalah reliabel (handal). Dengan demikian, dapat dikatakan bahwa instrumen penelitian yang digunakan dalam fungsi ukurnya tidak menimbulkan arti ganda sehingga dapat mengukur variabel kinerja karyawan pada PT Titipan Mas Area V Makassar.

Hasil uji reliabilitas instrumen dari variabel perencanaan diperoleh nilai Cronbach Alpha ( $\mathrm{r}$ hitung) 0,971-0,972 atau $\mathrm{r}$ hitung > $r$ tabel 0,195 , yang berarti setiap butir pernyataan dari variabel perencanaan yang digunakan dalam penelitian ini adalah reliabel (handal). Dengan demikian, dapat dikatakan bahwa instrumen penelitian yang digunakan dalam fungsi ukurnya tidak menimbulkan arti ganda sehingga dapat mengukur variabel perencanaan pada PT Titipan Mas Area V Makassar. 
Hasil uji reliabilitas instrumen dari variabel komunikasi diperoleh nilai Cronbach Alpha ( $r$ hitung) antara 0,971 - 0,972 atau $r$ hitung $>$ $r$ tabel 0,195 , yang berarti setiap butir pernyataan dari variabel komunikasi yang digunakan dalam penelitian ini adalah reliabel (handal). Dengan demikian, dapat dikatakan bahwa instrumen penelitian yang digunakan dalam fungsi ukurnya tidak menimbulkan arti ganda sehingga dapat mengukur komunikasi pada PT Titipan Mas Area V Makassar.

Nilai Cronbach Alpha dari keseluruhan butir pernyataan dalam instrumen penelitian diperoleh sebesar 0,973 (Lampiran 5), yang menunjukkan tingkat keandalan dari keseluruhan instrumen penelitian yang digunakan adalah sebesar $97,3 \%$. Artinya apabila kuesioner dalam penelitian ini akan digunakan secara berulang-ulang pada populasi akan memberikan nilai objektifitas, stabilitas, akurasi dan konsistensi yang tinggi untuk mengukur pengaruh variabel perencanaan dan komunikasi terhadap kinerja karyawan pada PT Titipan Mas Area V Makassar. 


\section{Analisis Deskriptif Variabel Penelitian}

Deskripsi variabel penelitian menampilkan jawaban responden dalam bentuk distribusi frekuensi. Deskripsi ini bertujuan mengetahui tanggapan responden terhadap masing-masing indikator dari variabel yang digunakan dalam penelitian ini, sehingga dapat diketahui kondisi masing-masing variabel secara umum. Penelitian ini menggunakan satu variabel terikat yaitu kinerja karyawan $(\mathrm{Y})$, dan 3 variabel bebas yaitu: perencanaan $\left(\mathrm{X}_{1}\right)$, dan komunikasi $\left(\mathrm{X}_{2}\right)$. Adapun masing-masing variabel tersebut akan dijelaskan, sebagai berikut:

\section{Kinerja karyawan $(Y)$}

Kinerja pengawai adalah hasil kerja yang dicapai karyawan dalam melakukan suatu pekerjaan berdasarkan tugas pokok dan fungsinya. Indikator kinerja karyawan adalah: (a) kualitas hasil kerja, (b) kuantitas hasil kerja, (c) efektivitas kerja, (d) efisiensi kerja, dan (e) kemandirian dalam bekerja.

Adapun data distribusi tanggapan responden terhadap variabel kinerja karyawan pada PT Titipan Mas Area V Makassar dapat dilihat pada Tabel 7. 
Tabel 7. Distribusi Tanggapan Responden terhadap Variabel Kinerja Karyawan $(\mathrm{Y})$

\begin{tabular}{|l|c|c|c|c|c|c|}
\hline \multirow{3}{*}{ Indikator } & \multicolumn{5}{|c|}{ Distribusi Frekuensi Jawaban } & \multirow{2}{*}{ Mean } \\
\cline { 2 - 6 } & $\begin{array}{c}\text { STS } \\
(1)\end{array}$ & $\begin{array}{c}\text { TS } \\
(2)\end{array}$ & $\begin{array}{c}\text { CS } \\
(3)\end{array}$ & $\begin{array}{c}\text { S } \\
(4)\end{array}$ & $\begin{array}{c}\text { SS } \\
(5)\end{array}$ & \\
\hline $\begin{array}{l}\text { Kualitas hasil } \\
\text { kerja }\end{array}$ & 0 & $\begin{array}{c}1 \\
(9)\end{array}$ & $\begin{array}{c}8 \\
(7,1)\end{array}$ & $\begin{array}{c}25 \\
(22,1)\end{array}$ & $\begin{array}{c}79 \\
(69,9)\end{array}$ & 4,61 \\
\hline $\begin{array}{l}\text { Kuantitas hasil } \\
\text { kerja }\end{array}$ & 0 & $\begin{array}{c}0 \\
(0,0)\end{array}$ & $\begin{array}{c}7 \\
(6,2)\end{array}$ & $\begin{array}{c}26 \\
(23,0)\end{array}$ & $\begin{array}{c}80 \\
(70,8)\end{array}$ & 4,65 \\
\hline Efektivitas kerja & 0 & $\begin{array}{c}1 \\
(9)\end{array}$ & $\begin{array}{c}12 \\
(10,6)\end{array}$ & $\begin{array}{c}22 \\
(19,5)\end{array}$ & $\begin{array}{c}78 \\
(69)\end{array}$ & 4,57 \\
\hline Efisiensi kerja & 0 & $\begin{array}{c}0 \\
(0,0)\end{array}$ & $\begin{array}{c}12 \\
(10,6)\end{array}$ & $\begin{array}{c}28 \\
(24,8)\end{array}$ & $\begin{array}{c}73 \\
(64,6)\end{array}$ & 4,54 \\
\hline $\begin{array}{l}\text { Kemandirian } \\
\text { dalam bekerja }\end{array}$ & 0 & $\begin{array}{c}1 \\
(9)\end{array}$ & $\begin{array}{c}11 \\
(9,7)\end{array}$ & $\begin{array}{c}23 \\
(20,4)\end{array}$ & $\begin{array}{c}78 \\
(69,0)\end{array}$ & 4,58 \\
\hline
\end{tabular}

Sumber: Data Primer Setelah Diolah, 2015 (Lampiran 4)

Keterangan: $\quad$ STS $=$ Sangat tidak setuju $S=$ Setuju

$$
\begin{aligned}
T S & =\text { Tidak Setuj } \quad \text { SS }=\text { Sangat setuju } \\
C S & =\text { Cukup setuju }
\end{aligned}
$$

Berdasarkan data pada Tabel 5 dapat dijelaskan bahwa indikator yang dominan dalam membentuk variabel kinerja karyawan pada PT Titipan Mas Area V Makassar adalah indikator kuantitas hasil kerja dengan nilai rata-rata 4,65, kemudian diikuti indikator kualitas hasil kerja dengan nilai rata-rata 4,61, indikator kemandirian dalam bekerja dengan nilai rata-rata 4,58 , dan indikator efektivitas kerja mempunyai nilai rata-rata 4,57. Sedangkan indikator efisiensi kerja mempunyai nilai rata-rata 4,54 memberikan proporsi terkecil dalam membentuk variabel kinerja karyawan. Sekalipun efisiensi kerja paling kecil kontribusinya, tidak berarti indikator tersebut dapat diabaikan. 
Kecederungan dari data tersebut menunjukkan bahwa kinerja pegawai PT Titipan Mas Area V Makassar tergolong baik, sehingga diharapkan dapat meningkat di masa akan datang.

\section{Perencanaan $\left(X_{1}\right)$}

Perencanaan adalah penentuan tujuan organisasi (perusahaan) dan kemudian menyajikan (mengartikulasikan) dengan jelas strategi-strategi (program), taktik-taktik (tata cara pelaksanaan program) dan operasi (tindakan) diperlukan untuk mencapai tujuan perusahaan secara menyeluruh. Indikator yang digunakan adalah: (a) penetapan tujuan organisasi yang jelas, (b) mendefinisikan situasi sekarang untuk mencapai keberhasilan, (c) mengenal dukungan dan kendala untuk mengatasi persoalan kerja, (d) mengembangkan premis perencanaan dengan membuat peramalan rencana, dan (e) mengembangkan metode pengawasan operasi rencana yang efektif.

Adapun data distribusi tanggapan responden terhadap variabel perencanaan pada PT Titipan Mas Area V Makassar dapat dilihat pada Tabel 8. 
Tabel 8. Distribusi Tanggapan Responden terhadap Variabel Perencanaan Kerja $\left(X_{1}\right)$

\begin{tabular}{|c|c|c|c|c|c|c|}
\hline \multirow{2}{*}{ Indikator } & \multicolumn{5}{|c|}{$\begin{array}{c}\text { Distribusi Frekuensi Jawaban } \\
\text { Responden/(\%) }\end{array}$} & \multirow{2}{*}{ Mean } \\
\hline & $\begin{array}{l}\text { STS } \\
(1)\end{array}$ & $\begin{array}{l}\text { TS } \\
(2)\end{array}$ & $\begin{array}{l}\text { CS } \\
(3)\end{array}$ & \begin{tabular}{|c|}
$S$ \\
$(4)$ \\
\end{tabular} & $\begin{array}{l}\text { SS } \\
(5)\end{array}$ & \\
\hline $\begin{array}{l}\text { Penetapan tujuan } \\
\text { organisasi yang jelas }\end{array}$ & 0 & 0 & $\begin{array}{c}7 \\
(6,2)\end{array}$ & $\left|\begin{array}{c}33 \\
(29,2)\end{array}\right|$ & $\begin{array}{c}73 \\
(64,6)\end{array}$ & 4,58 \\
\hline $\begin{array}{l}\text { Mendefinisikan situasi } \\
\text { sekarang untuk mencapai } \\
\text { keberhasilan }\end{array}$ & 0 & 0 & $\left.\begin{array}{c}25 \\
(22,1\end{array}\right)$ & $\begin{array}{c}23 \\
(20,4)\end{array}$ & $\begin{array}{c}65 \\
(57,5)\end{array}$ & 4,35 \\
\hline $\begin{array}{l}\text { Mengenal dukungan dan } \\
\text { kendala untuk mengatasi } \\
\text { persoalan kerja }\end{array}$ & 0 & 0 & $\begin{array}{c}7 \\
(6,2)\end{array}$ & $\begin{array}{c}49 \\
(43,4)\end{array}$ & $\begin{array}{c}57 \\
(50,4)\end{array}$ & 4,44 \\
\hline $\begin{array}{l}\text { Mengembangkan premis } \\
\text { perencanaan dengan } \\
\text { membuat peramalan } \\
\text { rencana }\end{array}$ & 0 & 0 & $\begin{array}{c}7 \\
(6,2)\end{array}$ & $\begin{array}{c}45 \\
(39,8)\end{array}$ & $\begin{array}{l}61 \\
(54)\end{array}$ & 4,48 \\
\hline $\begin{array}{l}\text { Mengembangkan metode } \\
\text { pengawasan operasi } \\
\text { rencana yang efektif }\end{array}$ & 0 & 0 & $\begin{array}{c}8 \\
(7,1)\end{array}$ & $\begin{array}{c}46 \\
(40,7)\end{array}$ & $\begin{array}{c}59 \\
(52,2)\end{array}$ & 4,45 \\
\hline
\end{tabular}

Sumber: Data Primer Setelah Diolah, 2015 (Lampiran 4)

$$
\begin{array}{lll}
\text { Keterangan: } & \text { STS }=\text { Sangat tidak setuju } & S=\text { Setuju } \\
& \text { TS }=\text { Tidak Setuju } & \text { SS }=\text { Sangat setuju } \\
\text { CS } & =\text { Cukup setuju } &
\end{array}
$$

Berdasarkan data pada Tabel 6 dapat dijelaskan bahwa indikator yang dominan dalam membentuk variabel perencanaan pada PT Titipan Mas Area V Makassar adalah indikator penetapan tujuan organisasi yang jelas mempunyai nilai rata-rata 4,58 , kemudian disusul indikator mengembangkan premis perencanaan untuk membuat peramalan rencana dengan nilai rata-rata 4,48, indikator mengembangkan metode pengawasan operasi rencana yang efektif dengan nilai rata-rata 4,45, dan indikator mengenal dukungan dan 
kendala untuk mengatasi persoalan kerja dengan nilai rata-rata 4,44. Sedangkan indikator mendefinisikan situasi sekarang untuk mencapai keberhasilan mempunyai nilai rata-rata 4,35 memberikan proporsi terkecil dalam membentuk variabel perencanaan. Sekalipun indikator mendefinisikan situasi sekarang kontribusinya kecil dalam membentuk variabel perencanaan, tidak berarti indikator tersebut dapat diabaikan. Kecederungan dari data menunjukkan bahwa variabel perencanaan mampu meningkatkan kinerja pegawai pada PT Titipan Mas Area V Makassar.

\section{Komunikasi $\left(\mathrm{X}_{2}\right)$}

Komunikasi adalah jalinan pengertian antara pihak yang satu dengan pihak yang lain, sehingga apa yang dikomunikasikan dapat dimengerti, dipikirkan dan akhirnya dilaksanakan. Indikator yang digunakan adalah: (a) Memiliki rasa percaya diri dalam memulai komunikasi, (b) Mendapat pendidikan/pelatihan mengenai komunikasi, (c) Berusaha menjalankan instruksi dengan baik, (d) Mampu memberikan saran dengan tepat saat berkomunikasi, dan (e) Bersedia menerima kritik dengan baik saat berkomunikasi.

Adapun data distribusi tanggapan responden terhadap variabel komunikasi pada PT Titipan Mas Area V Makassar dapat dilihat pada Tabel 9. 
Tabel 9. Distribusi Tanggapan Responden terhadap Variabel Komunikasi $\left(\mathrm{X}_{2}\right)$

\begin{tabular}{|l|c|c|c|c|c|c|}
\hline \multirow{2}{*}{\multicolumn{1}{|c|}{ Indikator }} & \multicolumn{5}{|c|}{ Distribusi Frekuensi Jawaban } & \multirow{2}{*}{ Mean } \\
\cline { 2 - 6 } & $\begin{array}{c}\text { STS } \\
(1)\end{array}$ & $\begin{array}{c}\text { TS } \\
(2)\end{array}$ & $\begin{array}{c}\text { CS } \\
(3)\end{array}$ & $\begin{array}{c}\text { (4) } \\
(4)\end{array}$ & $\begin{array}{c}\text { SS } \\
(5)\end{array}$ & \\
\hline $\begin{array}{l}\text { Memiliki rasa percaya } \\
\text { diri dalam memulai } \\
\text { komunikasi }\end{array}$ & 0 & 0 & $\begin{array}{c}7 \\
(6,2)\end{array}$ & $\begin{array}{c}22 \\
(19,5)\end{array}$ & $\begin{array}{c}84 \\
(74,3)\end{array}$ & 4,68 \\
\hline $\begin{array}{l}\text { Mendapat } \\
\text { pendidikan/pelatihan } \\
\text { mengenai komunikasi }\end{array}$ & 0 & 2 & 7 & 33 & 71 & 4,53 \\
\hline $\begin{array}{l}\text { Berusaha menjalankan } \\
\text { instruksi dengan baik }\end{array}$ & 0 & 0 & $\begin{array}{c}2 \\
(1,8)\end{array}$ & $\begin{array}{c}21 \\
(18,6)\end{array}$ & $\begin{array}{c}90 \\
(79,6)\end{array}$ & 4,78 \\
\hline $\begin{array}{l}\text { Mampu memberikan } \\
\text { saran dengan tepat saat } \\
\text { berkomunikasi }\end{array}$ & 0 & 0 & $\begin{array}{c}7 \\
(6,2)\end{array}$ & $\begin{array}{c}30 \\
(26,5)\end{array}$ & $\begin{array}{c}76 \\
(67,3)\end{array}$ & 4,61 \\
\hline $\begin{array}{l}\text { Bersedia menerima kritik } \\
\text { dengan baik saat } \\
\text { berkomunikasi }\end{array}$ & 0 & 0 & $\begin{array}{c}2 \\
(1,8)\end{array}$ & $\begin{array}{c}24 \\
(21,2)\end{array}$ & $\begin{array}{c}87 \\
(77,0)\end{array}$ & 4,75 \\
\hline
\end{tabular}

Sumber: Data Primer Setelah Diolah, 2015 (Lampiran 4)

Keterangan: $\quad$ STS $=$ Sangat tidak setuju $S=$ Setuju

$$
\begin{aligned}
& \mathrm{TS}=\text { Tidak setuju } \quad \text { SS = Sangat setuju } \\
& \mathrm{CS}=\text { Cukup setuju }
\end{aligned}
$$

Berdasarkan data pada Tabel 9 dapat dijelaskan bahwa indikator yang dominan dalam membentuk variabel komunikasi pada PT Titipan Mas Area V Makassar adalah indikator berusaha menjalankan instruksi dengan baik mempunyai nilai rata-rata 4,78 , kemudian disusul indikator bersedia menerima kritik dengan baik saat berkomunikasi dengan nilai rata-rata 4,75 , indikator memiliki rasa percaya diri dalam memulai komunikasi dengan nilai rata-rata 4,68, dan indikator mampu memberikan saran dengan tepat saat berkomunikasi dengan nilai rata- 
rata 4,61. Sedangkan indikator mendapat pendidikan atau pelatihan mengenai komunikasi mempunyai nilai rata-rata 4,53 memberikan proporsi terkecil dalam membentuk variabel komunikasi. Sekalipun indikator mendapat pendidikan atau pelatihan mengenai komunikasi memberikan kontribusi kecil dalam membentuk variabel komunikasi, tidak berarti indikator tersebut dapat diabaikan. Kecenderungan dari data menunjukkan bahwa variabel komunikasi mampu meningkatkan kinerja pegawai pada PT Titipan Mas Area V Makassar.

\section{Pengujian Asumsi Klasik}

\section{Uji Normalitas}

Uji normalitas bertujuan untuk menguji apakah dalam model regresi, variabel terikat dan variabel bebas keduanya mempunyai distribusi normal atau tidak. Model regresi yang baik adalah memiliki distribusi data normal atau mendekati normal. Pengujian normalitas data dalam penelitian ini dilakukan dengan melihat normal probability plot yang membandingkan distribusi kumulatif dari data sesungguhnya dengan distribusi kumulatif dari distribusi normal. Apabila didapatkan residual yang tidak tersebar secara normal pada suatu regresi, maka akan menghasilkan regresi yang tidak baik atau tidak konsisten dan efisien.

Adapun hasil pengujian grafis normalitas dalam penelitian ini, dapat dilihat pada Gambar 3. 


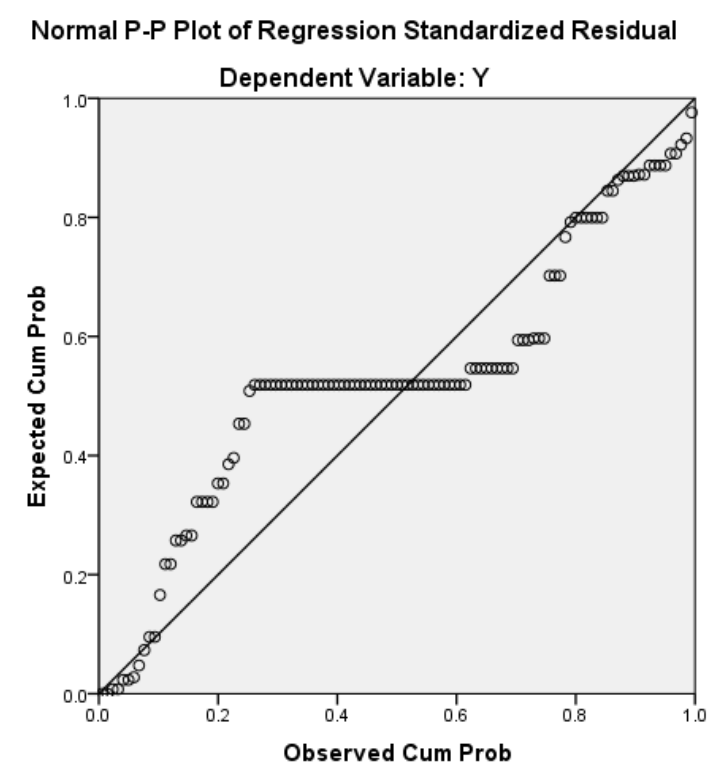

Gambar 3. Hasil Uji Normalitas (Lampiran 6)

Berdasarkan hasil pengujian grafik normal probability plot, tampak bahwa titik-titik menyebar di sekitar garis diagonal, serta penyebarannya mengikuti arus garis diagonal. Pengujian distribusi data yang dilakukan dengan metode grafis ini menunjukkan hasil yang dapat disimpulkan bahwa model regresi layak digunakan karena telah memenuhi asumsi normalitas.

\section{Uji Multikolinearitas}

Keberadaan multikolinearitas dalam suatu regresi akan mengganggu hasil regresi penelitian, sehingga tidak menghasilkan parameter yang efisien dan efektif yang akan membuat kesalahan dalam parameter yang dihasilkan. Regresi dikatakan baik jika suatu regresi tidak memiliki multikolinearitas di dalamnya sehingga tidak ada gangguan yang diharapkan akan terjadi pada regresi tersebut. 
Keberadaan multikolinearitas dapat dilihat melalui nilai VIF (Variance Inflation Factors) atau nilai toleransinya, yakni apabila nilai VIF $>10$ atau secara kebalikannya dengan melihat nilai toleransinya $<0,1$.

Adapun hasil perhitungan nilai VIF atau toleransi yang dilakukan untuk regresi dalam penelitian ini dapat dilihat pada Tabel 10 . 
Tabel 10. Hasil Uji Multikolinearitas

\section{Collinearity Statistics ${ }^{\mathrm{a}}$}

\begin{tabular}{|ll|c|c|}
\hline \multirow{2}{*}{ Model } & \multicolumn{2}{|c|}{ Collinearity Statistics } \\
\cline { 3 - 4 } & X1 & Tolerance & VIF \\
\hline & X2 & 0,256 & 3,911 \\
& & 0,256 & 3,911 \\
\hline
\end{tabular}

a. Dependent Variable: $Y$

Sumber: Hasil Penelitian, 2015 (Lampiran 7)

Hasil uji multikolinearitas pada Tabel 10 menunjukkan bahwa variabel perencanaan dan komunikasi memiliki nilai VIF yang lebih kecil 10 dan nilai toleransinya lebih besar 0,1 . Ini menunjukkan bahwa indikasi keberadaan multikolinearitas pada persamaan yang dilakukan dalam penelitian ini tidak terbukti atau tidak terdapat multikolinearitas dalam persamaan yang dilakukan atau hubungan yang terjadi antar variabel bebas dapat ditoleransi sehingga tidak akan mengganggu hasil regresi.

\section{Uji Heterokedastisitas}

Uji heterokedastisitas dalam penelitian dimaksudkan untuk melihat apakah pengambilan sampel dilakukan dengan benar pada populasi yang tepat atau dengan perkataan lain apakah terjadi ketidaksamaan varians dari residual regresi. Suatu model regresi yang mengandung heterokedastisitas akan menghasilkan parameter yang bias yang akan menyebabkan kesalahan dalam perlakuan. Suatu model regresi yang baik apabila di dalamnya tidak diperoleh heterokedastisitas melainkan homokedastisitas. 
Uji heterokedastisitas dapat diketahui dengan melihat plot grafik atau hubungan antara variabel terikat dengan nilai residualnya. Heterokedastisitas akan muncul apabila terdapat pola tertentu antar keduanya seperti bergelombang dan kontinyu atau menyempit atau melebar teratur, sedangkan homokedastisitas akan muncul apabila tidak diperoleh pola yang jelas atau titik-titik yang diperoleh menyebar di atas dan di bawah angka 0 pada sumbu $Y$.

Adapun hasil uji heterokedastisitas penelitian ini, dapat dilihat pada Gambar 4.

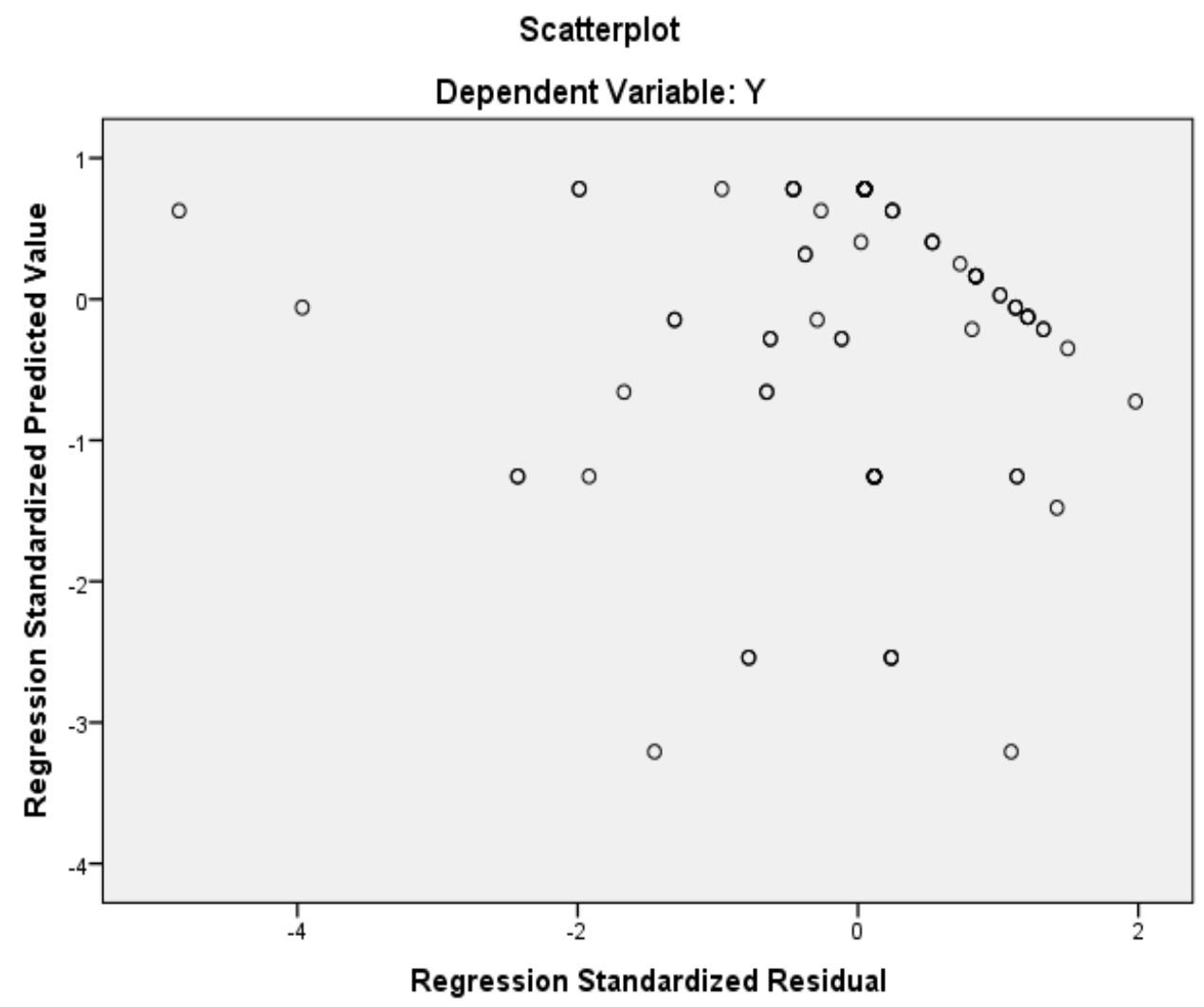

Gambar 4. Hasil Uji Heterokedastisitas (Lampiran 6) 
Berdasarkan hasil pengujian asumsi klasik dalam hal ini uji heterokedastisitas menunjukkan bahwa titik-titik menyebar di atas dan di bawah garis nol secara acak. Hal ini berarti model regresi yang digunakan dalam penelitian ini tidak menunjukkan adanya heterokedastisitas, melainkan homokedastisitas, dimana penelitian ini tidak menghasilkan parameter bias yang menyebabkan kesalahan dalam perlakuan.

\section{E. Pengujian Hipotesis Penelitian}

Berdasarkan hasil uji asumsi klasik yang meliputi uji normalitas, uji multikolienaritas, dan uji heterokedastisitas menunjukkan bahwa regresi berganda yang diestimasi telah memenuhi syarat asumsi-asumsi klasik sehingga diharapkan hasilnya akan baik dalam menganalisis pengaruh variabel perencanaan dan komunikasi terhadap kinerja karyawan pada PT Titipan Mas Area V Makassar. Pengujian terhadap hasil regresi yang diperoleh dilakukan pengujian secara serempak dengan menggunakan uji-F dan pengujian secara parsial menggunakan uji-t. Untuk lebih jelasnya akan diuraikan berikut ini.

\section{Pengujian Hipotesis secara Simultan}

Pengujian secara simultan bertujuan untuk melihat pengaruh perencanaan dan komunikasi terhadap kinerja karyawan pada PT Titipan Mas Area V Makassar dengan melihat nilai F-hitungnya. Adapun hasil pengujian secara simultan, dapat dilihat pada Tabel 11. 
Tabel 11. Pengujian secara Simultan (Uji F)

\begin{tabular}{|l|r|r|r|c|c|}
\hline \multicolumn{1}{|c|}{ ANOVA $^{\mathrm{b}}$} \\
\hline Model & \multicolumn{1}{c|}{$\begin{array}{c}\text { Sum of } \\
\text { Squares }\end{array}$} & \multicolumn{1}{c|}{ df } & Mean Square & $\mathrm{F}$ & \multicolumn{1}{c|}{ Sig. } \\
\hline 1 Regression & 28.476 & 2 & 14.238 & 92.200 & $.000^{2}$ \\
Residual & 16.987 & 110 & .154 & & \\
Total & 45.463 & 112 & & & \\
\hline
\end{tabular}

a. Dependent Variable: $Y$

b. Predictors: (Constant), X2, X1

Sumber: Hasil Analisis Data, 2015 (Lampiran 6)

Data pada Tabel 11 menunjukkan bahwa nilai F-hitung yang diperoleh adalah 92,200, sedangkan F-tabel (df1=2; df2 $=110 ; \alpha=0,05$ ) diperoleh 3,08 dengan tingkat signifikansi 0,000. Dengan demikian, nilai F-hitung $>$ F-tabel atau 92,2 > 3,08 yang berarti berpengaruh signifikan pada tingkat alpha yang sangat kecil (0\%). Dengan hasil ini, maka dapat disimpulkan bahwa secara semultan variabel perencanaan dan komunikasi berpengaruh signifikan dan positif terhadap kinerja karyawan pada PT Titipan Mas Area V Makassar.

\section{Pengujian Hipotesis secara Parsial}

Pengujian hipotesis secara parsial digunakan untuk melihat pengaruh perencanaan dan komunikasi terhadap kinerja karyawan pada PT Titipan Mas Area V Makassar. Hasil pengujiannya dapat dilihat melalui nilai t-hitungnya, sedangkan untuk melihat besarnya pengaruh digunakan angka beta atau standardized coefficient.

Adapun hasil pengujian secara parsial (t-hitung) dapat dilihat pada Tabel 12. 
Tabel 12. Pengujian secara Parsial (Uji-t)

\begin{tabular}{|l|r|r|r|r|r|}
\hline \multirow{2}{*}{ Model } & \multicolumn{2}{|c|}{$\begin{array}{c}\text { Unstandardized } \\
\text { Coefficients }\end{array}$} & $\begin{array}{c}\text { Standardized } \\
\text { Coefficients }\end{array}$ & & \\
\cline { 2 - 4 } & \multicolumn{1}{|c|}{ B } & Std. Error & \multicolumn{1}{c|}{ Beta } & \multicolumn{1}{c|}{ S } & \multicolumn{1}{c|}{ Sig. } \\
\hline $1 \quad$ (Constant) & .234 & .339 & & .690 & .492 \\
X1 & .389 & .123 & .366 & 3.175 & .002 \\
X2 & .560 & .142 & .454 & 3.938 & .000 \\
\hline
\end{tabular}

Sumber: Data Diolah, 2015 (Lampiran 6)

Berdasarkan pengujian secara parsial seperti pada Tabel 12 menunjukkan variabel perencanaan dan komunikasi secara individu berpengaruh signifikan dan positif terhadap kinerja karyawan pada PT Titipan Mas Area V Makassar. Hal ini dapat diketahui dari nilai t-hitung $>$ t-tabel yakni 1,980 diperoleh dari ( $d f 2=110 ; \alpha=0,05)$ dan juga dapat diketahui melalui tingkat signifikansinya dimana pada kolom sig./probabilitas pada tabel di atas diperoleh nilai signifikansi $<0,05$ yaitu variabel perencanaan dengan t-hitung $3,175>1,980$ atau signifikasi 0,002 $<0,05$, dan komunikasi dengan t-hitung 3,938 $>1,980$ atau signifikansi $0,000<0,05$. Dari kedua variabel bebas tersebut, yang memberikan pengaruh dominan adalah variabel komunikasi.

Selanjutnya dapat pula diketahui hasil persamaan regresi linier berganda dari model penelitian ini adalah sebagai berikut:

$Y=0,234+0,389 X_{1}+0,560 X_{2}$

Berdasarkan persamaan regresi linier berganda tersebut di atas, maka dapat diinterprestasi sebagai berikut: 
a. Konstanta $(\mathrm{b} 0)=0,234$, yang menunjukkan bahwa jika tidak ada perencanaan dan komunikasi, maka kinerja karyawan akan konstan yang jika diangkakan adalah 0,234.

b. $b 1=0,389$, yang menunjukkan bahwa perencanaan berpengaruh positif dan signifikan terhadap kinerja karyawan PT Titipan Mas Area V Makassar. Hal ini berarti semakin baik perencanaan, maka kinerja karyawan PT Titipan Mas Area V Makassar cenderung meningkat. Besarnya pengaruh variabel perencanaan terhadap kinerja karyawan dapat diketahui melalui angka beta atau standardized coefficient yaitu 0,389 atau 38,9 persen.

c. b2 $=0,560$, yang menunjukkan bahwa komunikasi berpengaruh positif dan signifikan terhadap kinerja karyawan pada PT Titipan Mas Area V Makassar. Hal ini berarti semakin baik komunikasi, maka kinerja karyawan pada PT Titipan Mas Area V Makassar cenderung meningkat. Besarnya pengaruh variabel komunikasi terhadap kinerja karyawan dapat diketahui melalui angka beta atau standardized coefficient yaitu 0,560 atau 56 persen.

Berdasarkan uraian di atas dapat diketahui bahwa dari ketiga variabel yang signifikan tersebut, ternyata variabel insentif yang mempunyai pengaruh dominan dalam meningkatkan kinerja karyawan pada PT Titipan Mas Area V Makassar, karena diperoleh angka beta atau standardized coefficient yang lebih besar dari variabel lainnya. Dengan demikian, hipotesis kedua dari penelitian ini diterima. 
3. Koefisien determinasi $\left(R^{2}\right)$ digunakan untuk menerangkan seberapa besar pengaruh dari seluruh variabel bebas (perencanaan, dan komunikasi) terhadap variabel terikat (kinerja karyawan). Perolehan nilai $R^{2}$ dapat dilihat pada Tabel 13 .

Tabel 13. Hasil Pengujian Koefisien Determinasi $\left(R^{2}\right)$

\begin{tabular}{|c|c|c|c|c|}
\hline \multicolumn{5}{|c|}{ Model Summary ${ }^{b}$} \\
\hline Model & $\mathrm{R}$ & R Square & Adjusted R Square & $\begin{array}{c}\text { Std. Error of the } \\
\text { Estimate }\end{array}$ \\
\hline 1 & $.791^{a}$ & .626 & .620 & .39297 \\
\hline
\end{tabular}

a. Predictors: (Constant), X2, X1

b. Dependent Variable: $Y$

Sumber: Hasil Analisis Data, 2015 (Lampiran 6)

Berdasarkan hasil pengujian determinasi tersebut di atas, dapat dijelaskan bahwa besarnya koefisien determinasi $\left(R^{2}\right)$ adalah 0,626 . Angka koefisien determinasi ini menyatakan besarnya kontribusi variabel perencanaan dan komunikasi terhadap kinerja karyawan pada PT Titipan Mas Area V Makassar adalah 62,6 persen, sedangkan sisanya sebesar $37,4 \%$ dipengaruhi faktor lain yang tidak dimasukkan dalam penelitian ini.

\section{F. Pembahasan}

Hasil penelitian menunjukkan variabel perencanaan dan komunikasi, baik secara simultan (bersama-sama) maupun secara parsial (individu) berpengaruh signifikan terhadap kinerja karyawan pada PT Titipan Mas Area V Makassar, dan di antara kedua variabel bebas yang dominan berpengaruh signifikan adalah variabel komunikasi. 
Selanjutnya pembahasan mengenai pengaruh variabel perencanaan dan komunikasi terhadap kinerja karyawan pada PT Titipan Mas Area V Makassar, akan diuraikan berikut ini.

\section{Pengaruh perencanaan terhadap kinerja karyawan}

Perencanaan adalah penentuan tujuan perusahaan dan kemudian menyajikan (mengartikulasikan) dengan jelas strategistrategi (program), taktik-taktik (tata cara pelaksanaan program) dan operasi (tindakan) diperlukan untuk mencapai tujuan perusahaan secara menyeluruh. Hasil pengujian secara parsial menunjukkan variabel perencanaan berpengaruh positif dan signifikan terhadap kinerja karyawan PT Titipan Mas Area V Makassar. Hal ini mengindikasikan ada hubungan yang searah antara perencanaan dengan kinerja karyawan, dalam arti jika perencanaan baik maka kinerja karyawan juga akan baik.

Peningkatan perencanaan sangat ditentukan oleh besarnya peran indikator yang membentuknya, yakni: (a) penetapan tujuan organisasi yang jelas, (b) mendefinisikan situasi sekarang untuk mencapai keberhasilan, (c) mengenal dukungan dan kendala untuk mengatasi persoalan kerja, (d) mengembangkan premis perencanaan dengan membuat peramalan rencana, (e) mengembangkan metode pengawasan operasi rencana yang efektif. Kelima indikator tersebut dapat diberdayakan secara maksimal guna mendukung peningkatan kinerja karyawan di masa akan datang. 
Indikator pembentuk utama variabel perencanaan adalah adalah indikator penetapan tujuan organisasi yang jelas mempunyai nilai rata-rata 4,58, kemudian disusul indikator mengembangkan premis perencanaan untuk membuat peramalan rencana dengan nilai rata-rata 4,48 , indikator mengembangkan metode pengawasan operasi rencana yang efektif dengan nilai rata-rata 4,45 , dan indikator mengenal dukungan dan kendala untuk mengatasi persoalan kerja dengan nilai rata-rata 4,44. Sedangkan indikator mendefinisikan situasi sekarang untuk mencapai keberhasilan mempunyai nilai rata-rata 4,35 memberikan proporsi terkecil dalam membentuk variabel perencanaan. Sekalipun indikator mendefinisikan situasi sekarang kontribusinya kecil dalam membentuk variabel perencanaan, tidak berarti indikator tersebut dapat diabaikan. Oleh karena itu, untuk mengefektifkan perencanaan, manajer PT Titipan Mas Area V Makassar harus mampu mendefinisikan situasi sekarang berdasarkan pengalaman masa lalu untuk mencapai tujuan organisasi secara keseluruhan di masa akan datang.

Sritomo (2006:334) mendefinisikan perencanaan sebagai sebuah proses untuk menetapkan ke arah mana kegiatan harus ditujukan dengan mengidentifikasi segala prasyarat dan kondisi agar bisa sampai ketempat tujuan dengan cara dan usaha yang paling efektif dan efisien. Pada intinya perencanaan dibuat sebagai upaya untuk merumuskan apa yang sesungguhnya ingin dicapai oleh sebuah organisasi atau perusahaan serta bagaimana sesuatu yang 
ingin dicapai tersebut dapat diwujudkan melalui serangkaian rumusan rencana kegiatan tertentu. Perencanaan yang baik sangat ditentukan oleh keberhasilan pelaksanaan proses perencanaan. Oleh karena itu, perencanaan menjadi syarat mutlak untuk diperhatikan, karena menjadi tolak ukur dalam meningkatkan kinerja karyawan.

Berdasarkan analisa tersebut, maka dapat disimpulkan bahwa perencanaan merupakan salah satu faktor yang mampu meningkatkan kinerja karyawan pada PT Titipan Mas Area V Makassar. Oleh karena itu, perencanaan perlu diefektifkan terutama pada indikator-indikator yang memberikan proporsi terendah agar kinerja karyawan dapat ditingkatkan di masa akan datang.

Hasil penelitian membuktikan bahwa perencanaan memberikan pengaruh positif dan signifikan terhadap kinerja karyawan PT Titipan Mas Area $\mathrm{V}$ Makassar, yang berarti semakin baik perencanaan maka kinerja karyawan akan semakin baik pula. Penelitian ini juga membuktikan penelitian yang dilakukan oleh Sudirman (2011) dan Rosliani Kadir (2011), perencanaan berpengaruh signifikan terhadap kinerja pegawai.

\section{Pengaruh komunikasi terhadap kinerja karyawan}

Komunikasi adalah jalinan pengertian antara pihak yang satu dengan pihak yang lain, sehingga apa yang dikomunikasikan dapat dimengerti, dipikirkan yang akhirnya dilaksanakan. Hasil 
pengujian secara parsial menunjukkan bahwa variabel komunikasi berpengaruh positif dan signifikan terhadap kinerja karyawan pada PT Titipan Mas Area V Makassar. Hal ini mengindikasikan ada hubungan yang searah antara komunikasi dengan kinerja karyawan, dalam arti semakin efektif komunikasi maka kinerja karyawan juga cenderung akan meningkat.

Adanya pengaruh signifikan dari variabel komunikasi terhadap kinerja karyawan sangat ditentukan oleh besarnya peran indikator yang membentuk variabel tersebut, yakni: (a) Memiliki rasa percaya diri dalam memulai komunikasi, (b) Mendapat pendidikan/pelatihan mengenai komunikasi, (c) Berusaha menjalankan instruksi dengan baik, (d) Mampu memberikan saran dengan tepat saat berkomunikasi, dan (e) Bersedia menerima kritik dengan baik saat berkomunikasi.. Kelima indikator tersebut telah diberdayakan secara maksimal guna mendukung peningkatan kinerja karyawan di masa akan datang.

Indikator pembentuk utama variabel komunikasi adalah indikator berusaha menjalankan instruksi dengan baik mempunyai nilai rata-rata 4,78 , kemudian disusul indikator bersedia menerima kritik dengan baik saat berkomunikasi dengan nilai rata-rata 4,75 , indikator memiliki rasa percaya diri dalam memulai komunikasi dengan nilai rata-rata 4,68, dan indikator mampu memberikan saran dengan tepat saat berkomunikasi dengan nilai rata-rata 4,61. Sedangkan indikator mendapat pendidikan atau pelatihan mengenai komunikasi mempunyai nilai rata-rata 4,53 memberikan proporsi terkecil dalam membentuk 
variabel komunikasi. Oleh karena itu, perlu upaya peningkatan kemampuan pegawai melalui kegiatan pendidikan dan pelatihan terkait dengan komunikasi, sehingga diharapkan mampu mendukung peningkatan kinerja karyawan pada PT Titipan Mas Area V Makassar.

Komunikasi adalah vital bagi operasi perusahaan untuk berhasil dan menjadi suatu bagian integral dari suatu proses manajemen. Robbins (2007) mengemukakan komunikasi merupakan sebuah pentransferan makna maupun pemahaman makna kepada orang lain dalam bentuk lambang-lambang, simbol, atau bahasa-bahasa tertentu sehingga orang yang menerima informasi memahami maksud dari informasi tersebut. Komunikasi dalam organisasi sangatlah penting, dimana organisasi merupakan suatu kesatuan atau perkumpulan yang terdiri atas orang-orang atau bagian-bagian yang di dalmnya terdapat aktivitas kerja sama berdasarkan aturan-aturan untuk mencapai tujuan bersama. Oleh karena itu, komunikasi menjadi syarat mutlak untuk diperhatikan, karena menjadi tolak ukur dalam meningkatkan kinerja karyawan.

Berdasarkan analisa tersebut, maka dapat disimpulkan bahwa variabel komunikasi merupakan salah satu faktor mampu meningkatkan kinerja karyawan pada PT Titipan Mas Area V Makassar. Oleh karena itu, komunikasi perlu ditingkatkan terutama pada indikator yang memberikan proporsi terendah agar kinerja karyawan dapat ditingkatkan di masa akan datang. 
Hasil penelitian membuktikan bahwa komunikasi memberikan pengaruh positif dan signifikan terhadap kinerja karyawan pada PT Titipan Mas Area V Makassar, yang berarti semakin efektif komunikasi maka kinerja karyawan akan semakin meningkat pula. Penelitian ini juga membuktikan penelitian yang dilakukan oleh Husein Anwar (2010), Sudirman (2011), dan Suryadi (2011) bahwa komunikasi yang baik dalam perusahaan akan meningkatkan kinerja pegawai. 


\section{BAB VI \\ SIMPULAN DAN SARAN}

\section{A. Simpulan}

Berdasarkan uraian dan hasil analisis yang ditunjukkan pada bab sebelumnya, dapat disimpulkan hal-hal sebagai berikut:

1. Hasil penelitian menunjukkan baik secara simultan maupun secara parsial variabel perencanaan $(p=0,002<0,05)$, dan komunikasi $(p=0,000<0,05)$ berpengaruh positif dan signifikan terhadap kinerja karyawan pada PT Titipan Mas Area V Makassar. Dengan demikian, hipotesis pertama dari penelitian ini diterima atau terbukti.

2. Dari kedua variabel bebas yang digunakan dalam menentukan tingkat kinerja karyawan, ternyata variabel komunikasi dengan angka beta atau standardized coefficient yaitu 0,454 mempunyai pengaruh dominan dalam meningkatkan kinerja karyawan pada PT Titipan Mas Area V Makassar.

\section{B. Saran}

Berdasarkan kesimpulan di atas, maka penulis memberikan beberapa saran sebagai berikut:

1. Seyogyanya perencanaan dan komunikasi perlu dipertimbangkan dalam menyusun suatu kebijakan yang terkait dengan upaya peningkatan kinerja karyawan terutama pada indikator yang 
memberikan kontribusi lebih besar dalam membentuk kedua variabel tersebut sehingga diharapkan kinerja karyawan dapat ditingkatkan.

2. Mengingat variabel komiunikasi memberikan pengaruh dominan terhadap kinerja karyawan, maka disarankan mempertahankan kebijakan yang terkait dengan kebijakan komunikasi termasuk indikator yang membentuknya, sedangkan variabel perencanaan diharapkan terus diefektifkan terutama pada indikator yang memberikan proporsi terendah guna mendukung peningkatan kinerja karyawan di masa akan datang. 


\section{DAFTAR PUSTAKA}

Ali, 2007. Hubungan Efektifitas Komunikasi Organisasi dengan Kinerja Guru, (Survei di SMK Nusantara Ciputat), UIN Syarif Hidayatullah, Jakarta.

Alwi, Syafaruddin, 2001. Manajemen Sumber Daya Manusia Strategi Keunggulan Kompetitif, BPFE, Yogyakarta.

Anwar, 2000. Pengertian Kinerja dan Dinamika Kerja. Gramedia Pustaka, Jakarta.

Arfah, Ahmad dan Anshory, Mislich. 2005. Pengaruh Kesesuaian Kompensasi Terhadap Kinerja Dan Kepuasan Kerja Karyawan (Study Pada Perusahaan Air Minum di Batam). Majalah Ekonomi, tahun XV, No. 3A.

Bernardin H., John and Russel, 2001. Human Resources Management: An Experimental Approach. Mc. Graw Hill Inc., Singapura.

Betris, Michele, 2002. The Performance and High Work by Human Resource. Published by Prentice Hall, Ohio University Press.

Cangara, Hafied. 2006. Pengantar IImu Komunikasi. RajaGrafindo Persada. Jakarta.

Cushway, Barry, 1996. Manajemen Sumber Daya Manusia. Terjemahan, PT Elex Media Komputindo, Jakarta.

Daud, 2013. Efektifitas Komunikasi Pemerintahan Terhadap Pelayanan Publik di Kota Manado, Universitas Sam ratulangi, manado.

Davis, Mathis, 2005. Manajemen Pengembangan Kinerja SDM. Penerbit Rajawali Press, Jakarta.

Davis, Keith and Newstrom J.W, 2005. Perilaku Dalam Organisasi, Jilid I dan II Alih Bahasa Agus Dharma, Erlangga, Jakarta.

Dessler, Gary, 2001. Manajemen Sumber Daya Manusia. Terjemahan, Edisi Ketujuh, Erlangga, Jakarta.

Endang, Maliki, 2006. Komunikasi Efektif, Modul Pendidikan dan Pelatihan Prajabatan Golongan III, Lembaga Administrasi Negara. Jakarta.

Fathoni, Abdurrahmat, 2006. Manajemen Sumber Daya Manusia. Rineka Cipta, Jakarta.

Gomes, F. C. 2005. Manajemen Sumber Daya Manusia. Edisi II. Andi. Yogyakarta. 
Gunawan, 2006. Manajemen Sumber Daya Manusia. Tarsita, Bandung.

Hair, Joseph F. Jr., R.E. Anderson, R.I. Tatham dan W.C. Black. 1998. Multivariate Data Analysis. $5^{\text {th }}$ edition. Prentice-Hall International, Inc., Upper Saddle River, New Jersey.

Handoko, T. Hani, 2002. Manajemen Personalia dan Sumber Daya Manusia. Penerbit BPFE, Yogyakarta.

--------, 2003. Manajemen Sumber Daya Manusia. Penerbit BPFE, Yogyakarta.

Hasibuan, S.P. Melayu, 2004, Manajemen Sumber Daya Manusia, Bumi Aksara Jakarta.

Mangkunegara, A. P. 2005. Perilaku dan Budaya Organisasi. Refika Aditama, Bandung.

Martoyo, Susilo, 2007. Manajemen Sumber Daya Manusia. BPFE, Yogyakarta.

Mulyana, Deddy. 2004. IImu Komunikasi Suatu Pengantar. Remaja Rosdakarya. Bandung.

Muhlis, Sudarman, 2005. Kinerja dan Penilaian Kinerja SDM. Penerbit Intan Pariwara, Jakarta.

Musanef, 2001. Faktor-Faktor yang Berpengaruh terhadap Kinerja SDM. Penerbit Gunung Agung, Jakarta.

Nawawi, Hadari. 2002. Perencanaan Sumber Daya Manusia, Gajah Mada University Press, Bandung.

Nurdin, 2000. Sistem Komunikasi Indonesia. Publishing. Yogyakarta.

Pangabean, M., 2004. Manajemen Sumber Daya Manusia, Ghalia Indonesia, Bogor Selatan.

Partanto, 2001. Manajemen Sumber Daya Manusia untuk Perusahaan. PT Raja Grafindo Persada, Jakarta.

Rivai, V., 2008. Manajemen Sumber Daya Manusia Untuk Perusahaan, Murai Kencana, Jakarta.

Robbins, Stephen, P., 2007. Perilaku Organisasi: Konsep, Kontroversial, dan Aplikasi, Terjemahan. Jakarta: PT Prenhallindo.

Ruky, Ahmad S. 2003. Sistem Manajemen Kinerja. Gramedia, Jakarta.

Sedarmayanti, 2009. Manajemen Sumber Daya Manusia. Refika Aditama, Bandung. 
Setyanto, R., 2002. Penilaian Kerja Karyawan. Penerbit Harvarindo, Jakarta.

Siagian, Sondang, 2004. Manajemen Sumberdaya Manusia, Penerbit Bina Aksara, Jakarta.

Simamora, H., 2001. Manajemen Sumber Daya Manusia. Edisi 2. Bagian Penerbitan STIE YKPN, Yogyakarta.

Sukirno, 2004. Manajemen Sumber Daya Manusia. Pustaka Setia. Bandung.

Terry, G.R., 2005. Prinsip-Prinsip Manajemen. Alih Bahasa oleh J. Smith D.F.M, Bumi Aksara, Jakarta.

Wahid, Subondo, 2004. Manajemen Sumber Daya Manusia. Penerbit Bina Ilmu, Solo.

Handoko, T. Hani. 2001. Manajemen Personalia dan Sumber Daya Manusia. Edisi kedua, BPFE, Yogyakarta.

Hasibuan, H. Malayu, S.P. 2002. Manajemen Sumber Daya Manusia. Bumi Aksara. Jakarta.

Jalaluddin, 2008. Psikologi Komunikasi. Rosda Karya, Jakarta.

Rivai, V. \& Sagala, E. J., 2009, Manajemen Sumber daya Manusia Untuk Perusahaan: Dari Teori ke Praktik. (Edisi II), PT Raja Grafindo Perkasa, Jakarta.

Robbins, 2002. Prinsif-prinsif Perilaku Organisasi, Edisi kelima, Erlangga, Jakarta.

Robbins, S.P., and Coulter, M. 2001. Management (5th ed.), New Jersey, Prentice Hall, Inc.

Sritomo, 2006. Pengantar Teknik dan Manajemen Industri, Guna Widya. Surabaya.

Umar, 2003. Metode Riset Perilaku Organisasi, Gramedia Pustaka Utama, Jakarta. 
Lampiran 1. Angket Penelitian

\section{KUESIONER PENELITIAN}

\section{IDENTITAS RESPONDEN:}

1. Jenis Kelamin

2. Umur

3. Pendidikan terakhir

\section{Instruksi:}

Aspek-aspek penilaian faktor kinerja karyawan pada PT Titipan Mas Area V Makassar, antara lain: perencanaan dan komunikasi, dengan menggunakan Skala Likert, yaitu:
(a) Sangat setuju
$=$ bobot 5
(b) Setuju
$=$ bobot 4
(c) Cukup setuju
$=$ bobot 3
(d) Tidak setuju
$=$ bobot 2
(e) Sangat tidak setuju
$=$ bobot 1

Kuesioner ini mencakup 5 aspek penilaian variabel. Pilihlah salah satu alternatif dari lima alternatif yang tersedia (, , b, c, d dan e) dengan cara memberi tanda check list $(\sqrt{ })$ pada salah satu kotak yang anda pilih.

Bapak/lbu/Sdr(i) diminta dengan hormat memberi penilaian dengan mengisi daftar kuesioner ini. Kerahasiaan dari Bapak/lbu/Sdr(i) dari hasil penelitian ini akan dijamin dan hanya untuk kepentingan ilmiah dan akademis.

Semakin obyektif penilaian anda semakin valid hasil penilaian ini.

Peneliti 


\section{PENILAIAN VARIABEL-VARIABEL PENELITIAN}

\section{Variabel kinerja karyawan $(Y)$}

\begin{tabular}{|c|l|c|c|c|c|c|}
\hline No & \multicolumn{1}{|c|}{ Pernyataan } & STS & TS & CS & S & SS \\
\hline 1. & $\begin{array}{l}\text { Pegawai menunjukkan kualitas kerja } \\
\text { yang baik. }\end{array}$ & & & & & \\
\hline 2. & $\begin{array}{l}\text { Pegawai mampu memberikan } \\
\text { kuantitas kerja sesuai target yang } \\
\text { ditentukan. }\end{array}$ & & & & & \\
\hline 3. & $\begin{array}{l}\text { Pegawai menerapkan efisiensi kerja } \\
\text { dengan bekerja tepat waktu. }\end{array}$ & & & & & \\
\hline 4. & $\begin{array}{l}\text { Pegawai berupaya meningkatkan } \\
\text { efektifitas kerja agar tujuan organisasi } \\
\text { dapat tercapai. }\end{array}$ & $\begin{array}{l}\text { Pegawai memiliki kemandirian dalam } \\
\text { bekerja }\end{array}$ & & & & \\
\hline 5. & & & & \\
\hline
\end{tabular}

\section{Variabel perencanaan $\left(X_{1}\right)$}

\begin{tabular}{|c|l|c|c|c|c|c|}
\hline No & \multicolumn{1}{|c|}{ Pernyataan } & STS & TS & CS & S & SS \\
\hline 1. & $\begin{array}{l}\text { Pegawai mampu menetapkan tujuan } \\
\text { organisasi yang jelas }\end{array}$ & & & & & \\
\hline 2. & $\begin{array}{l}\text { Pegawai mampu mendefinisikan } \\
\text { situasi sekarang untuk mencapai } \\
\text { keberhasilan }\end{array}$ & & & & & \\
\hline 3. & $\begin{array}{l}\text { Pegawai mampu mengenal dukungan } \\
\text { dan kendala untuk mengatasi } \\
\text { persoalan kerja }\end{array}$ & & & & & \\
\hline 4. & $\begin{array}{l}\text { Pegawai mampu mengembangkan } \\
\text { premis perencanaan dengan } \\
\text { membuat peramalan rencana }\end{array}$ & & & & & \\
\hline 5. & $\begin{array}{l}\text { Pegawai mampu mengembangkan } \\
\text { metode pengawasan operasi rencana } \\
\text { yang efektif }\end{array}$ & & & & & \\
\hline
\end{tabular}


C. Variabel komunikasi $\left(X_{2}\right)$

\begin{tabular}{|c|l|c|c|c|c|c|}
\hline No & \multicolumn{1}{|c|}{ Pernyataan } & STS & TS & CS & S & SS \\
\hline 1. & $\begin{array}{l}\text { Pegawai memiliki rasa percaya diri } \\
\text { dalam memulai komunikasi }\end{array}$ & & & & & \\
\hline 2. & $\begin{array}{l}\text { Pegawai mendapat pendidikan atau } \\
\text { pelatihan mengenai komunikasi }\end{array}$ & & & & & \\
\hline 3. & $\begin{array}{l}\text { Pegawai berusaha menjalankan } \\
\text { instruksi dengan baik }\end{array}$ & & & & \\
\hline 4. & $\begin{array}{l}\text { Pegawai mampu memberikan saran } \\
\text { dengan tepat saat berkomunikasi. }\end{array}$ & & & & & \\
\hline 5. & $\begin{array}{l}\text { Pegawai bersedia menerima kritik } \\
\text { dengan baik saat berkomunikasi. }\end{array}$ & & & & & \\
\hline
\end{tabular}

Terima kasih. 
Lampiran 3. Distribusi Frekuensi Karakteristik Responden

\section{Frequency Table}

\begin{tabular}{|ll|r|r|r|r|}
\hline & & & & \\
& & Jrequency & Percent & Valid Percent & $\begin{array}{c}\text { Cumulative } \\
\text { Percent }\end{array}$ \\
\hline Valid & Laki-Laki & 55 & 48.7 & 48.7 & 48.7 \\
& Perempuan & 58 & 51.3 & 51.3 & 100.0 \\
& Total & 113 & 100.0 & 100.0 & \\
\hline
\end{tabular}

Tingkat pendidikan

\begin{tabular}{|ll|r|r|r|r|}
\hline & & & & Cumulative \\
& & Frequency & Percent & Valid Percent & Percent \\
\hline Valid & Diploma & 24 & 21.2 & 21.2 & 21.2 \\
& S1 & 50 & 44.2 & 44.2 & 65.5 \\
S2 & 5 & 4.4 & 4.4 & 69.9 \\
SLTA & 34 & 30.1 & 30.1 & 100.0 \\
Total & 113 & 100.0 & 100.0 & \\
\hline
\end{tabular}

Tingkat umur

\begin{tabular}{|ll|r|r|r|r|}
\hline & & & & Cumulative \\
& & Frequency & Percent & Valid Percent & Percent \\
\hline Valid & 28 & 12 & 10.6 & 10.6 & 10.6 \\
& 30 & 10 & 8.8 & 8.8 & 19.5 \\
32 & 5 & 4.4 & 4.4 & 23.9 \\
33 & 4 & 3.5 & 3.5 & 27.4 \\
34 & 21 & 18.6 & 18.6 & 46.0 \\
35 & 4 & 3.5 & 3.5 & 49.6 \\
36 & 12 & 10.6 & 10.6 & 60.2 \\
37 & 10 & 8.8 & 8.8 & 69.0 \\
38 & 4 & 3.5 & 3.5 & 72.6 \\
40 & 8 & 7.1 & 7.1 & 79.6 \\
41 & 3 & 2.7 & 2.7 & 82.3 \\
42 & 5 & 4.4 & 4.4 & 86.7 \\
44 & 4 & 3.5 & 3.5 & 90.3 \\
46 & 4 & 3.5 & 3.5 & 93.8 \\
48 & 7 & 6.2 & 6.2 & 100.0 \\
Total & 113 & 100.0 & 100.0 & \\
\hline
\end{tabular}


Masa kerja

\begin{tabular}{|ll|r|r|r|r|}
\hline & & & Cumulative \\
& & Frequency & Percent & Valid Percent & \multicolumn{2}{|c|}{ Percent } \\
\hline Valid & 3 & 3 & 2.7 & 2.7 & 2.7 \\
& 4 & 5 & 4.4 & 4.4 & 7.1 \\
& 5 & 9.7 & 9.7 & 16.8 \\
6 & 11 & 5.3 & 22.1 \\
7 & 6 & 5.3 & 5.3 & 27.4 \\
8 & 6 & 5.3 & 13.3 & 40.7 \\
9 & 15 & 13.3 & 4.4 & 45.1 \\
10 & 5 & 4.4 & 4.4 & 49.6 \\
11 & 5 & 4.4 & 6.2 & 55.8 \\
12 & 7 & 6.2 & 2.7 & 58.4 \\
13 & 3 & 2.7 & 3.5 & 61.9 \\
14 & 4 & 3.5 & 3.5 & 65.5 \\
16 & 4 & 3.5 & 11.5 & 77.0 \\
18 & 13 & 11.5 & 7.1 & 84.1 \\
19 & 8 & 7.1 & 8.0 & 92.0 \\
20 & 9 & 8.0 & 4.4 & 96.5 \\
21 & 5 & 4.4 & 3.5 & 100.0 \\
Total & 4.5 & 100.0 & \\
\hline
\end{tabular}


Lampiran 4. Analisis Distribusi Frekuensi Variabel Penelitian

\section{Frequencies of Kinerja karyawan}

\begin{tabular}{|ll|r|r|r|r|r|}
\hline \multicolumn{1}{|c|}{ Statistics } \\
\hline & & \multicolumn{1}{c|}{ Y.1 } & \multicolumn{1}{c|}{ Y.2 } & \multicolumn{1}{c|}{ Y.3 } & \multicolumn{1}{l|}{ Y.4 } & \multicolumn{1}{c|}{ Y.5 } \\
\hline N & Valid & 113 & 113 & 113 & 113 & 113 \\
& Missing & 0 & 0 & 0 & 0 & 0 \\
Mean & & 4.61 & 4.65 & 4.57 & 4.54 & 4.58 \\
\hline
\end{tabular}

\begin{tabular}{|ll|r|r|r|r|}
\hline & & Y.1 & & \multicolumn{2}{c|}{$\begin{array}{c}\text { Cumulative } \\
\text { Percent }\end{array}$} \\
\hline Valid & tidak setuju & 1 & .9 & .9 & .9 \\
& cukup setuju & 8 & 7.1 & 7.1 & 8.0 \\
& setuju & 25 & 22.1 & 22.1 & 30.1 \\
sangat setuju & 79 & 69.9 & 69.9 & 100.0 \\
Total & 113 & 100.0 & 100.0 & \\
\hline
\end{tabular}

\begin{tabular}{|ll|r|r|r|r|}
\hline \multicolumn{7}{|c|}{ Y.2 } & \multicolumn{2}{c|}{ Cumulative } \\
& & Frequency & Percent & Valid Percent & \multicolumn{2}{c|}{ Percent } \\
\hline Valid & cukup setuju & 7 & 6.2 & 6.2 & 6.2 \\
& setuju & 26 & 23.0 & 23.0 & 29.2 \\
& sangat setuju & 80 & 70.8 & 70.8 & 100.0 \\
& Total & 113 & 100.0 & 100.0 & \\
\hline
\end{tabular}

\begin{tabular}{|ll|r|r|r|r|}
\hline \multicolumn{1}{|c|}{ Y.3 } \\
& Frequency & \multicolumn{1}{|c|}{ Percent } & Valid Percent & $\begin{array}{c}\text { Cumulative } \\
\text { Percent }\end{array}$ \\
\hline Valid & tidak setuju & 1 & .9 & .9 & .9 \\
& cukup setuju & 12 & 10.6 & 10.6 & 11.5 \\
& setuju & 22 & 19.5 & 19.5 & 31.0 \\
& sangat setuju & 78 & 69.0 & 69.0 & 100.0 \\
Total & 113 & 100.0 & 100.0 & \\
\hline
\end{tabular}

\begin{tabular}{|c|c|c|c|c|c|}
\hline \multicolumn{6}{|c|}{ Y.4 } \\
\hline & & Frequency & Percent & Valid Percent & $\begin{array}{c}\text { Cumulative } \\
\text { Percent }\end{array}$ \\
\hline \multirow[t]{4}{*}{ Valid } & cukup setuju & 12 & 10.6 & 10.6 & 10.6 \\
\hline & setuju & 28 & 24.8 & 24.8 & 35.4 \\
\hline & sangat setuju & 73 & 64.6 & 64.6 & 100.0 \\
\hline & Total & 113 & 100.0 & 100.0 & \\
\hline
\end{tabular}




\begin{tabular}{|ll|r|r|r|r|}
\hline \multicolumn{1}{|c|}{ Y.5 } & & \multicolumn{2}{c|}{$\begin{array}{c}\text { Cumulative } \\
\text { Percent }\end{array}$} \\
\hline Valid & tidak setuju & Frequency & Percent & Valid Percent & .9 \\
& cukup setuju & 1 & .9 & .9 & 10.6 \\
& 11 & 9.7 & 9.7 & 31.0 \\
setuju & 23 & 20.4 & 20.4 & 100.0 \\
sangat setuju & 78 & 69.0 & 69.0 & \\
Total & 113 & 100.0 & 100.0 & \\
\hline
\end{tabular}

\section{Frequencies of Perencanaan}

\begin{tabular}{|ll|r|r|r|r|r|}
\multicolumn{7}{|c|}{ Statistics } \\
\hline & & X1.1 & \multicolumn{1}{c|}{ X1.2 } & X1.3 & \multicolumn{1}{c|}{ X1.4 } & \multicolumn{1}{c|}{ X1.5 } \\
\hline N & Valid & 113 & 113 & 113 & 113 & 113 \\
& Missing & 0 & 0 & 0 & 0 & 0 \\
Mean & 4.58 & 4.35 & 4.44 & 4.48 & 4.45 \\
\hline
\end{tabular}

$\mathrm{X} 1.1$

\begin{tabular}{|ll|r|r|r|r|}
\hline & & & & \multicolumn{2}{|c|}{$\begin{array}{c}\text { Cumulative } \\
\text { Percent }\end{array}$} \\
\hline Valid & cukup setuju & 7 & 6.2 & 6.2 & 6.2 \\
& setuju & 33 & 29.2 & 29.2 & 35.4 \\
& sangat setuju & 73 & 64.6 & 64.6 & 100.0 \\
& Total & 113 & 100.0 & 100.0 & \\
\hline
\end{tabular}

$\mathrm{X} 1.2$

\begin{tabular}{|c|c|c|c|c|c|}
\hline & & Frequency & Percent & Valid Percent & $\begin{array}{l}\text { Cumulative } \\
\text { Percent }\end{array}$ \\
\hline \multirow[t]{4}{*}{ Valid } & cukup setuju & 25 & 22.1 & 22.1 & 22.1 \\
\hline & setuju & 23 & 20.4 & 20.4 & 42.5 \\
\hline & sangat setuju & 65 & 57.5 & 57.5 & 100.0 \\
\hline & Total & 113 & 100.0 & 100.0 & \\
\hline
\end{tabular}

X1.3

\begin{tabular}{|ll|r|r|r|r|}
\hline & \multicolumn{2}{|c|}{$\mathbf{X} 1 . \mathbf{3}$} & \multicolumn{2}{c|}{$\begin{array}{c}\text { Cumulative } \\
\text { Percent }\end{array}$} \\
\hline Valid & cukup setuju & 7 & 6.2 & 6.2 & 6.2 \\
& setuju & 49 & 43.4 & 43.4 & 49.6 \\
& sangat setuju & 57 & 50.4 & 50.4 & 100.0 \\
Total & 113 & 100.0 & 100.0 & \\
\hline
\end{tabular}


$X 1.4$

\begin{tabular}{|ll|r|r|r|r|}
\hline & & & & \multicolumn{2}{|c|}{$\begin{array}{c}\text { Cumulative } \\
\text { Percent }\end{array}$} \\
\hline Valid & cukup setuju & 7 & 6.2 & 6.2 & 6.2 \\
& setuju & 45 & 39.8 & 39.8 & 46.0 \\
& sangat setuju & 61 & 54.0 & 54.0 & 100.0 \\
& Total & 113 & 100.0 & 100.0 & \\
\hline
\end{tabular}

$X 1.5$

\begin{tabular}{|ll|r|r|r|r|}
\hline & & & & \multicolumn{2}{|c|}{$\begin{array}{c}\text { Cumulative } \\
\text { Percent }\end{array}$} \\
\hline Valid & cukup setuju & 8 & 7.1 & Valid Percent & 7.1 \\
& setuju & 46 & 40.7 & 40.7 & 47.8 \\
& sangat setuju & 59 & 52.2 & 52.2 & 100.0 \\
Total & 113 & 100.0 & 100.0 & \\
\hline
\end{tabular}

\section{Frequencies of Komunikasi}

Statistics

\begin{tabular}{|ll|r|r|r|r|r|}
\hline & & \multicolumn{1}{|c|}{ X2.1 } & \multicolumn{1}{|c|}{ X2.2 } & X2.3 & \multicolumn{1}{|c|}{ X2.4 } & \multicolumn{1}{c|}{ X2.5 } \\
\hline $\mathrm{N}$ & Valid & 113 & 113 & 113 & 113 & 113 \\
& Missing & 0 & 0 & 0 & 0 & 0 \\
Mean & & 4.68 & 4.53 & 4.78 & 4.61 & 4.75 \\
\hline
\end{tabular}

X2.1

\begin{tabular}{|ll|r|r|r|r|}
\hline & & & & \multicolumn{2}{c|}{$\begin{array}{c}\text { Cumulative } \\
\text { Percent }\end{array}$} \\
\hline Valid & cukup setuju & 7 & 6.2 & Valid Percent & 6.2 \\
& setuju & 22 & 19.5 & 19.5 & 25.7 \\
& sangat setuju & 84 & 74.3 & 74.3 & 100.0 \\
& Total & 113 & 100.0 & 100.0 & \\
\hline
\end{tabular}

X2.2

\begin{tabular}{|ll|r|r|r|r|}
\hline & & & & \multicolumn{2}{|c|}{ Cumulative } \\
& & Frequency & Percent & Valid Percent & \multicolumn{2}{|c|}{ Percent } \\
\hline Valid & tidak setuju & 2 & 1.8 & 1.8 & 1.8 \\
& cukup setuju & 7 & 6.2 & 6.2 & 8.0 \\
& setuju & 33 & 29.2 & 29.2 & 37.2 \\
& sangat setuju & 71 & 62.8 & 62.8 & 100.0 \\
Total & 113 & 100.0 & 100.0 & \\
\hline
\end{tabular}


X2.3

\begin{tabular}{|ll|r|r|r|r|}
\hline & & & & \multicolumn{2}{|c|}{$\begin{array}{c}\text { Cumulative } \\
\text { Percent }\end{array}$} \\
\hline Valid & cukup setuju & 2 & 1.8 & Valid Percent & 1.8 \\
& setuju & 21 & 18.6 & 18.6 & 20.4 \\
& sangat setuju & 90 & 79.6 & 79.6 & 100.0 \\
Total & 113 & 100.0 & 100.0 & \\
\hline
\end{tabular}

X2.4

\begin{tabular}{|ll|r|r|r|r|}
\hline & & & & \multicolumn{2}{|c|}{$\begin{array}{c}\text { Cumulative } \\
\text { Percent }\end{array}$} \\
\hline Valid & cukup setuju & 7 & 6.2 & Valid Percent & 6.2 \\
& setuju & 30 & 26.5 & 26.5 & 32.7 \\
& sangat setuju & 76 & 67.3 & 67.3 & 100.0 \\
Total & 113 & 100.0 & 100.0 & \\
\hline
\end{tabular}

X2.5

\begin{tabular}{|c|c|c|c|c|c|}
\hline & & Frequency & Percent & Valid Percent & $\begin{array}{c}\text { Cumulative } \\
\text { Percent }\end{array}$ \\
\hline \multirow[t]{4}{*}{ Valid } & cukup setuju & 2 & 1.8 & 1.8 & 1.8 \\
\hline & setuju & 24 & 21.2 & 21.2 & 23.0 \\
\hline & sangat setuju & 87 & 77.0 & 77.0 & 100.0 \\
\hline & Total & 113 & 100.0 & 100.0 & \\
\hline
\end{tabular}


Lampiran 5. Hasil Analisis Uji Validitas dan Reliabilitas

\section{Scale: ALL VARIABLES}

\begin{tabular}{|ll|r|r|}
\hline \multicolumn{1}{|c|}{ Case Processing Summary } \\
\begin{tabular}{|ll|r|r|}
\hline Cases & N & \multicolumn{1}{c|}{$\%$} \\
& Valid & 113 & 100.0 \\
& Excluded & 0 & .0 \\
& Total & 113 & 100.0 \\
\hline
\end{tabular}
\end{tabular}

a. Listwise deletion based on all variables in the procedure.

Reliability Statistics

\begin{tabular}{|r|r|}
\hline $\begin{array}{c}\text { Cronbach's } \\
\text { Alpha }\end{array}$ & N of Items \\
\hline .973 & 15 \\
\hline
\end{tabular}

Item Statistics

\begin{tabular}{|l|r|r|r|}
\hline & Mean & Std. Deviation & $\mathrm{N}$ \\
\hline Y.1 & 4.63 & .657 & 113 \\
Y.2 & 4.63 & .601 & 113 \\
Y.3 & 4.57 & .718 & 113 \\
Y.4 & 4.54 & .682 & 113 \\
Y.5 & 4.58 & .705 & 113 \\
X1.1 & 4.58 & .608 & 113 \\
X1.2 & 4.35 & .823 & 113 \\
X1.3 & 4.44 & .611 & 113 \\
X1.4 & 4.48 & .614 & 113 \\
X1.5 & 4.45 & .627 & 113 \\
X2.1 & 4.68 & .587 & 113 \\
X2.2 & 4.53 & .695 & 113 \\
X2.3 & 4.78 & .458 & 113 \\
X2.4 & 4.61 & .604 & 113 \\
X2.5 & 4.75 & .473 & 113 \\
\hline
\end{tabular}


Item-Total Statistics

\begin{tabular}{|l|r|r|r|r|}
\hline & $\begin{array}{c}\text { Scale Mean if } \\
\text { Item Deleted }\end{array}$ & $\begin{array}{c}\text { Scale Variance } \\
\text { if Item Deleted }\end{array}$ & $\begin{array}{c}\text { Corrected Item- } \\
\text { Total } \\
\text { Correlation }\end{array}$ & $\begin{array}{c}\text { Cronbach's } \\
\text { Alpha if Item } \\
\text { Deleted }\end{array}$ \\
\hline Y.1 & 63.97 & 57.812 & .797 & .972 \\
Y.2 & 63.97 & 58.723 & .774 & .972 \\
Y.3 & 64.04 & 56.124 & .889 & .970 \\
Y.4 & 64.06 & 57.130 & .835 & .971 \\
Y.5 & 64.03 & 56.115 & .909 & .970 \\
X1.1 & 64.02 & 58.393 & .801 & .972 \\
X1.2 & 64.25 & 55.206 & .844 & .971 \\
X1.3 & 64.16 & 58.046 & .836 & .971 \\
X1.4 & 64.12 & 58.056 & .831 & .971 \\
X1.5 & 64.15 & 57.808 & .840 & .971 \\
X2.1 & 63.92 & 58.288 & .846 & .971 \\
X2.2 & 64.07 & 57.031 & .828 & .971 \\
X2.3 & 63.82 & 60.040 & .840 & .972 \\
X2.4 & 63.99 & 58.045 & .847 & .971 \\
X2.5 & 63.85 & 59.950 & .823 & .972 \\
\hline
\end{tabular}

Scale Statistics

\begin{tabular}{|r|r|r|r|}
\hline Mean & Variance & Std. Deviation & N of Items \\
\hline 68.60 & 66.206 & 8.137 & 15 \\
\hline
\end{tabular}


Lampiran 6. Hasil Analisis Regresi Linier Berganda

\section{Regression}

\begin{tabular}{|l|c|r|r|r|r|r|}
\hline \multicolumn{7}{|c|}{ Descriptive Statistics } \\
\hline & N & Minimum & Maximum & Mean & Std. Deviation & Variance \\
\hline Y & 113 & 2.40 & 5.00 & 4.5876 & .63712 & .406 \\
X1 & 113 & 3.00 & 5.00 & 4.4619 & .59886 & .359 \\
X2 & 113 & 2.80 & 5.00 & 4.6708 & .51611 & .266 \\
Valid N (listwise) & 113 & & & & & \\
\hline
\end{tabular}

\begin{tabular}{|c|c|c|c|c|}
\hline \multicolumn{5}{|c|}{ Correlations } \\
\hline & & $Y$ & $\mathrm{X} 1$ & X2 \\
\hline \multirow[t]{3}{*}{ Pearson Correlation } & $\mathrm{Y}$ & 1.000 & .757 & .769 \\
\hline & $\mathrm{X} 1$ & .757 & 1.000 & .863 \\
\hline & $\mathrm{X} 2$ & .769 & .863 & 1.000 \\
\hline \multirow[t]{3}{*}{ Sig. (1-tailed) } & $\mathrm{Y}$ & & .000 & .000 \\
\hline & $\mathrm{X} 1$ & .000 & & .000 \\
\hline & X2 & .000 & .000 & \\
\hline \multirow[t]{3}{*}{$\mathrm{N}$} & $\mathrm{Y}$ & 113 & 113 & $\overline{113}$ \\
\hline & $\mathrm{X} 1$ & 113 & 113 & 113 \\
\hline & $\mathrm{x} 2$ & 113 & 113 & 113 \\
\hline
\end{tabular}

\section{Variables Entered/Removed ${ }^{\mathrm{a}}$}

\begin{tabular}{|l|l|c|l|}
\hline Model & $\begin{array}{c}\text { Variables } \\
\text { Entered }\end{array}$ & $\begin{array}{c}\text { Variables } \\
\text { Removed }\end{array}$ & Method \\
\hline 1 & $\mathrm{X} 2, \mathrm{X} 1^{\mathrm{b}}$ & & Enter \\
\hline
\end{tabular}

a. Dependent Variable: $Y$

b. All requested variables entered.

\begin{tabular}{|l|r|r|c|r|r|}
\hline \multicolumn{7}{|c|}{ Model Summary $^{\text {bodel }}$} & $\mathrm{R}$ & R Square & $\begin{array}{c}\text { Adjusted R } \\
\text { Square }\end{array}$ & $\begin{array}{c}\text { Std. Error of the } \\
\text { Estimate }\end{array}$ & Durbin-Watson \\
\hline 1 & $.791^{\mathrm{a}}$ & .626 & .620 & .39297 & 1.342 \\
\hline
\end{tabular}

a. Predictors: (Constant), X2, X1

b. Dependent Variable: $Y$

\section{ANOVA $^{\mathrm{a}}$}

\begin{tabular}{|ll|r|r|r|r|r|}
\hline Model & & Sum of Squares & \multicolumn{1}{|c|}{ df } & Mean Square & F & Sig. \\
\hline 1 & Regression & 28.476 & 2 & 14.238 & 92.200 & $.000^{\mathrm{b}}$ \\
& Residual & 16.987 & 110 & .154 & & \\
& Total & 45.463 & 112 & & & \\
\hline
\end{tabular}

a. Dependent Variable: $Y$

b. Predictors: (Constant), X2, X1 
Coefficients $^{a}$

\begin{tabular}{|c|c|c|c|c|c|c|c|c|}
\hline \multirow{2}{*}{\multicolumn{2}{|c|}{ Model }} & \multicolumn{2}{|c|}{$\begin{array}{c}\text { Unstandardized } \\
\text { Coefficients }\end{array}$} & \multirow{2}{*}{$\begin{array}{c}\begin{array}{c}\text { Standardized } \\
\text { Coefficients }\end{array} \\
\text { Beta }\end{array}$} & \multirow[b]{2}{*}{$t$} & \multirow[b]{2}{*}{ Sig. } & \multicolumn{2}{|c|}{$\begin{array}{c}\text { Collinearity } \\
\text { Statistics }\end{array}$} \\
\hline & & $\mathrm{B}$ & Std. Error & & & & Tolerance & VIF \\
\hline \multirow[t]{3}{*}{1} & (Constant) & .234 & .339 & & .690 & .492 & & \\
\hline & X1 & .389 & .123 & .366 & 3.175 & .002 & 256 & 3.911 \\
\hline & $\mathrm{X} 2$ & .560 & .142 & .454 & 3.938 & .000 & .256 & 3.911 \\
\hline
\end{tabular}

a. Dependent Variable: $Y$

Collinearity Diagnostics ${ }^{a}$

\begin{tabular}{|c|c|c|c|c|c|c|}
\hline \multirow[b]{2}{*}{ Model } & \multirow[b]{2}{*}{ Dimension } & \multirow[b]{2}{*}{ Eigenvalue } & \multirow{2}{*}{$\begin{array}{l}\text { Condition } \\
\text { Index }\end{array}$} & \multicolumn{3}{|c|}{ Variance Proportions } \\
\hline & & & & (Constant) & $\mathrm{X} 1$ & $\mathrm{X} 2$ \\
\hline \multirow[t]{3}{*}{1} & 1 & 2.989 & 1.000 & .00 & .00 & .00 \\
\hline & 2 & .009 & 17.754 & .80 & .14 & .02 \\
\hline & 3 & .002 & 39.736 & 20 & .85 & .98 \\
\hline
\end{tabular}

a. Dependent Variable: Y

Residuals Statistics ${ }^{a}$

\begin{tabular}{|l|r|r|r|r|r|}
\hline & \multicolumn{1}{|c|}{ Minimum } & Maximum & Mean & Std. Deviation & \multicolumn{1}{c|}{$\mathrm{N}$} \\
\hline Predicted Value & 2.9704 & 4.9815 & 4.5876 & .50423 & 113 \\
Residual & -1.90364 & .77811 & .00000 & .38944 & 113 \\
Std. Predicted Value & -3.207 & .781 & .000 & 1.000 & 113 \\
Std. Residual & -4.844 & 1.980 & .000 & .991 & 113 \\
\hline
\end{tabular}

a. Dependent Variable: $Y$

\section{Charts}

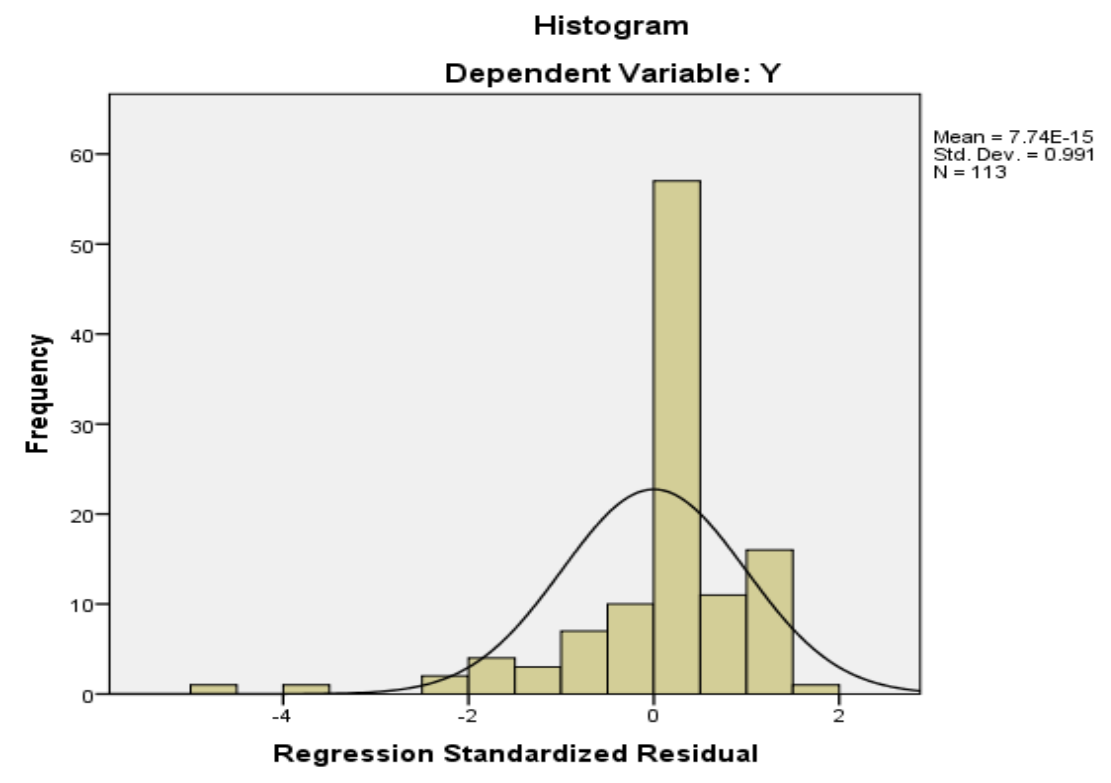


Normal P-P Plot of Regression Standardized Residual

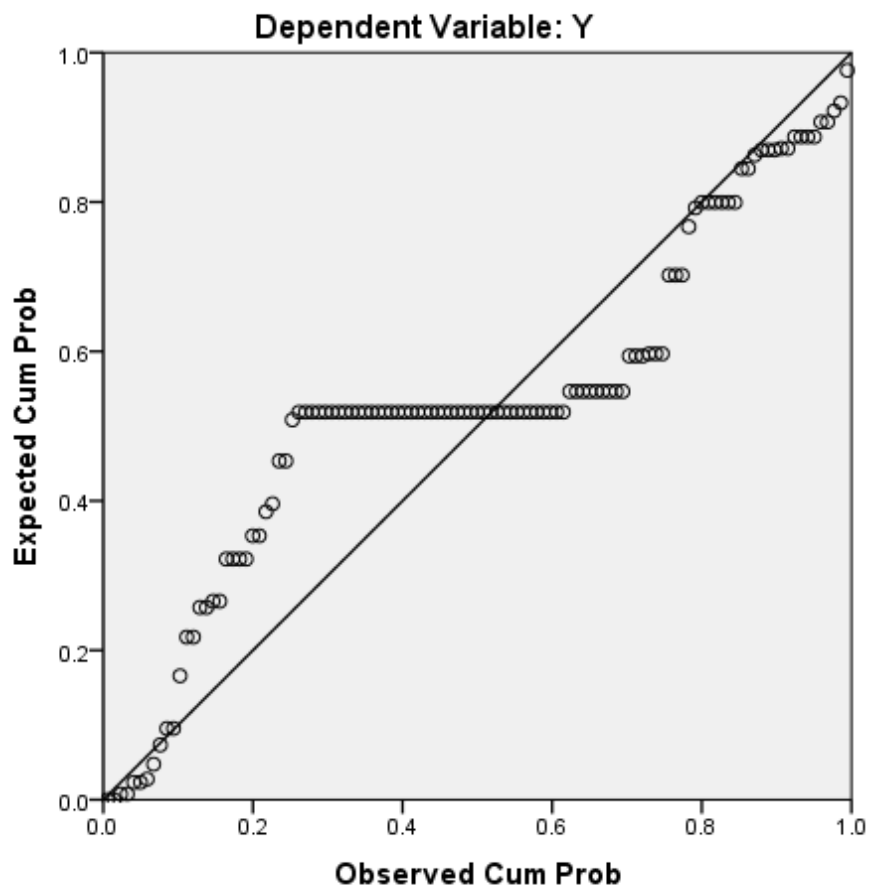

Scatterplot

Dependent Variable: $Y$

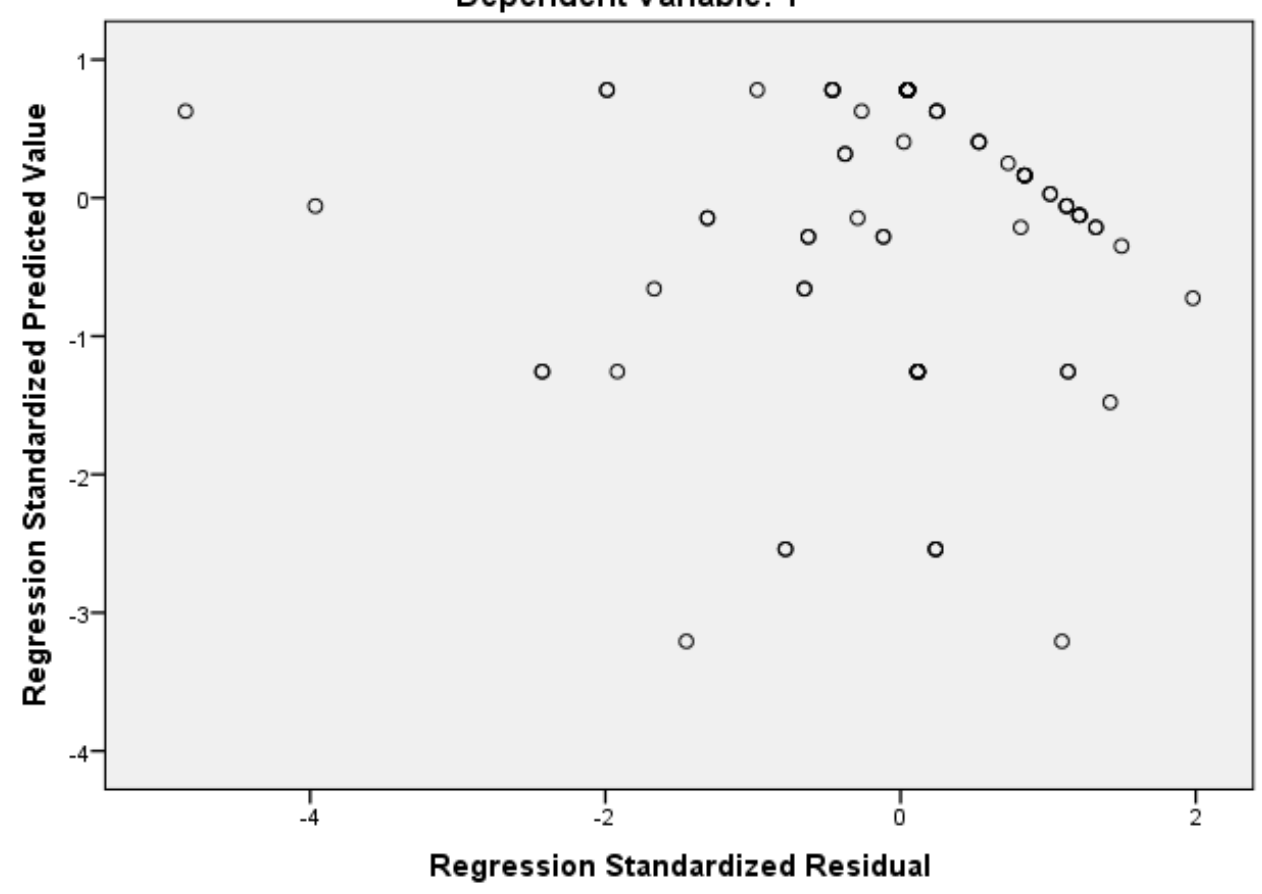


Partial Regression Plot

Dependent Variable: $Y$

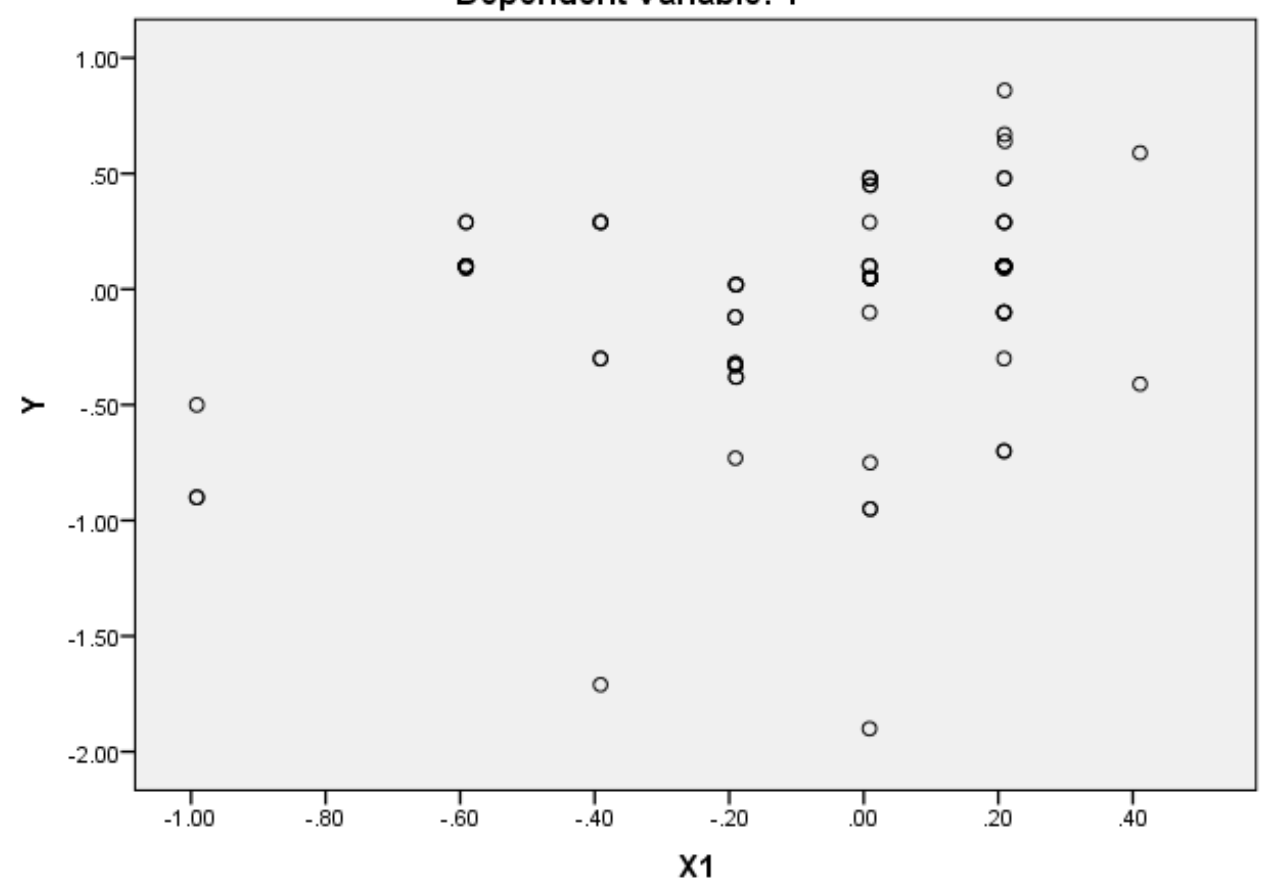

Partial Regression Plot

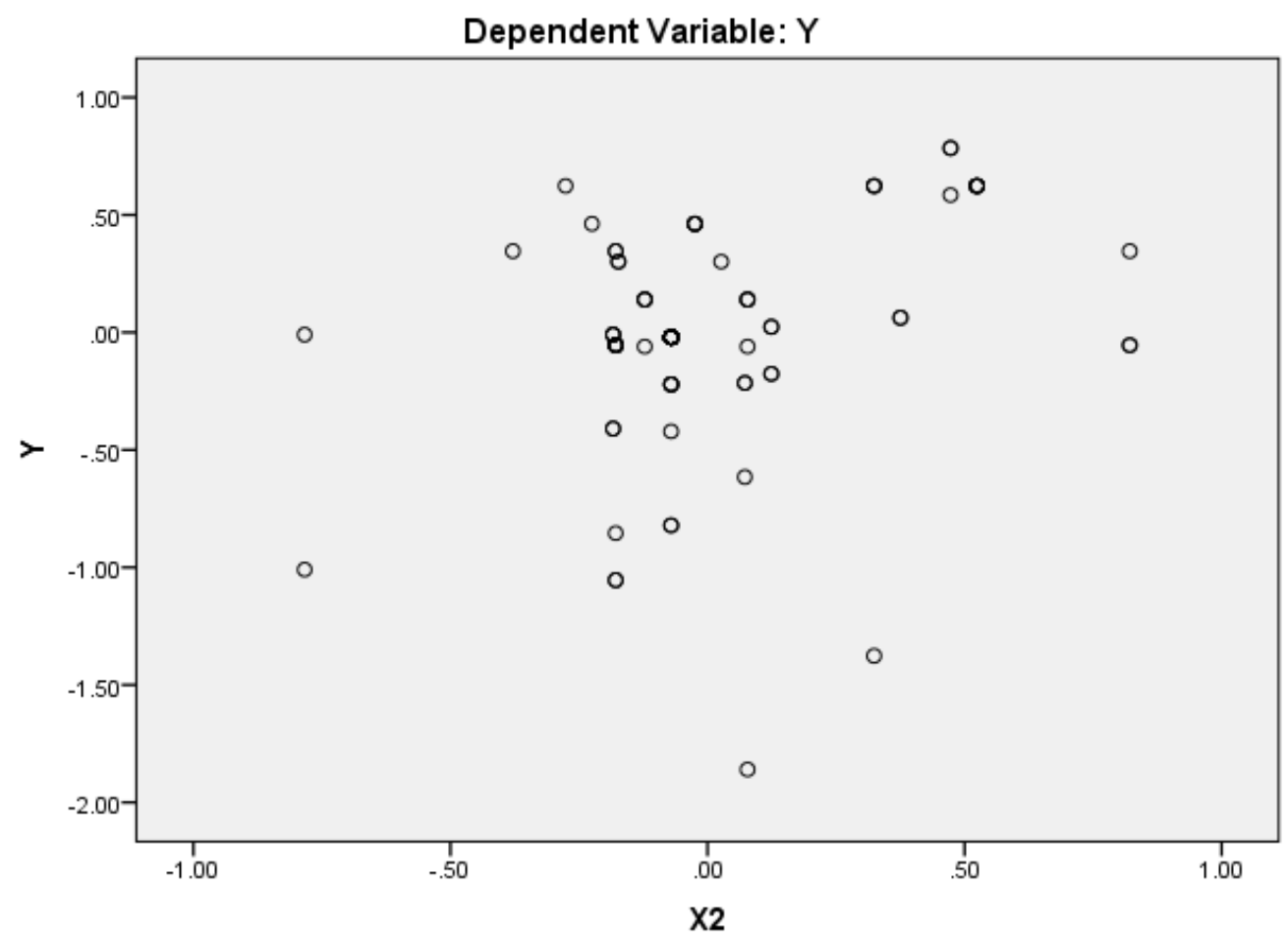

